
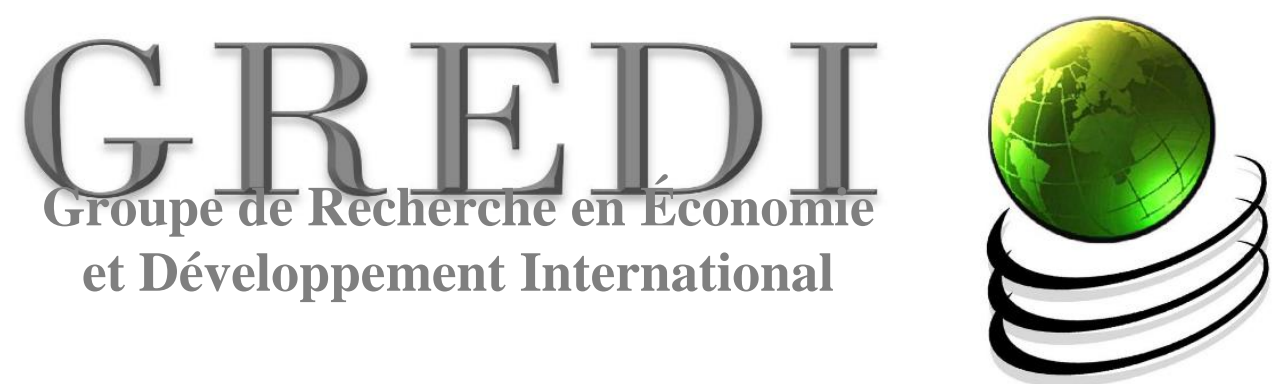

Cahier de recherche / Working Paper

17-06

\title{
From Fossil Fuels to Renewables: The Role of Electricity Storage
}

\author{
Itziar LAZKANO \\ Linda NØSTBAKKEN \\ Martino PELLI
}

C UNIVERSITÉ DE

ก SHERBROOKE 


\title{
From Fossil Fuels to Renewables: The Role of Electricity Storage*
}

\author{
Itziar Lazkano $^{\dagger} \quad$ Linda Nøstbakken ${ }^{\ddagger} \quad$ Martino Pelli $\S$
}

March 17, 2017

\begin{abstract}
Electricity storage represents a solution to curb emissions by enabling more use of intermittent renewable energy. Our goal is to empirically analyze the determinants of innovation in electricity storage and its role in fostering technological innovations in renewable and conventional electricity generation. Using a global firm-level data set of electricity patents from 1963 to 2011, we find that better electricity storage promotes innovation not only in renewable energy but also in conventional technologies. Specifically, our estimates show that an additional storage patent increases the probability to apply for patents in renewable energy and efficiencyimproving fossil fuel technologies two years from now by $1.11 \%$ and $0.66 \%$, respectively. This implies that improved electricity storage technologies can boost the energy efficiency of conventional, fossil fuel-fired power plants as well as increase the use of renewable electricity. Thus, the ability of electricity storage to curb carbon emissions depends on: the competitiveness of renewable energy against conventional electricity generation, and conventional power generation mix as storage increases fossil-fuel efficiency and reduces ramping costs.
\end{abstract}

Keywords: Electricity storage; Innovation; Electricity; Directed technical change.

JEL Classification Codes: O3, O4, O5, Q2, Q3, Q4, Q5

\footnotetext{
${ }^{*}$ We are grateful to four anonymous referees and the journal's editors, Branko Bošković, Antoine Dechezleprêtre, Mads Greaker, Gilles Lafforgue, Linh Pham, Stephen Polasky, Aude Pommeret, Joseph Swierzbinski, and seminar and conference participants at the Montreal Natural Resources and Environmental Economics Workshop, Kiel University, the Norwegian School of Economics, Ryerson University, Université Laval, University of Aberdeen, University of Alberta, University of Leicester, University of Minnesota, University of Sherbrooke, University of WisconsinMadison, University of Wisconsin-Milwaukee, Tinbergen-European Research Council Conference 2016, Association of Environmental and Resource Economists Conference 2015, BEEER 2015, the CU Environmental and Resource Economics Workshop 2015, Société Canadienne de Science Économique 2015, the CESifo Area Conference on Energy and Climate Economics 2014, and the World Congress of Environmental and Resource Economists 2014 for helpful comments on earlier versions. We also thank Andreas Bjelland Eriksen, Sahar Milani, Valerie Rubalcava, Alyssa Willert, and Kelli Zeleski for excellent research assistance constructing the data set. Finally, the majority of the research was conducted during Lazkano's visit at the Department of Economics of the Norwegian School of Economics. Lazkano is indebted to the department for their hospitality and financial support.

${ }^{\dagger}$ Assistant Professor, Economics Department, University of Wisconsin-Milwaukee. (lazkano@uwm.edu).

${ }^{\ddagger}$ Professor, Department of Economics, Norwegian School of Economics. (linda.nostbakken@nhh.no).

${ }^{\S}$ Assistant Professor, Economics Department, Université de Sherbrooke. (martino.pelli@usherbrooke.ca).
} 


\section{Introduction}

Concerns over climate change have led society to seek alternatives to reduce carbon emissions. To that end, many call for a shift in energy production from fossil fuels toward renewables. Although renewable energy can provide a clean source of electricity, fossil fuels still account for the vast majority of the world's electricity generation. ${ }^{1}$ As a consequence, electricity generation is currently the single largest carbon emitter globally, and with energy demands continuing to grow rapidly, innovation in the electricity sector is an important channel for curbing carbon emissions. Although innovation has already resulted in new and improved renewable technologies, electricity storage is often considered to be a key innovation challenge for meeting renewable goals because large-scale storage solutions can boost the use of intermittent renewable energy in the grid mix.

Our main goal is to study the role of electricity storage for innovation in the electricity sector. Specifically, we ask two main questions. First, how do better storage technologies affect innovation in renewable and conventional electricity generation? Second, how does innovation in electricity generation affect technological advancements in storage? To answer these questions, we develop testable hypotheses based on a directed technological change framework, and then, we test these hypotheses using a global firm-level database of patents related to electricity generation and storage from 1963 to 2011.

The most widely used form of electricity storage is pumped hydro, which accounts for over $90 \%$ of the current global storage capacity and has been used commercially since the 1890s. However, current innovation efforts mainly target other technologies, including batteries or compressed air storage, because the potential to expand the use of traditional pumped-hydro storage is limited by the availability of suitable sites. ${ }^{2}$ Many of these initiatives seek a breakthrough in batteries, but governments and private companies also direct innovation efforts to a multitude of other possible solutions. $^{3}$ These include ways to use cheap and easily available materials, including air and water, as the storage media (e.g., compressed air and flywheels), hydrogen-based technologies, and electrical and thermal storage.

We start by developing testable hypotheses that builds on the directed technological change framework used by Acemoglu et al. (2012) and Aghion et al. (2016). Specifically, we consider three types of innovation: innovation in renewable electricity generation, innovation in conventional electricity generation, and innovation in electricity storage. Innovation in electricity generation results

\footnotetext{
${ }^{1}$ According to the International Energy Agency, in 2013, $67.2 \%$ of world electricity production came from conventional fossil fuel-powered plants. Hydroelectric plants provided $16.6 \%$, nuclear plants $10.6 \%$, biofuels and waste $2.0 \%$, and the rest came from geothermal, solar, wind, and other sources (IEA, 2015).

${ }^{2}$ Figure B.1 shows global installed storage capacity by technology from 1950 onward.

${ }^{3}$ Indeed, the media describe the occurrence of a technology race in electricity storage, with scientists searching for game-changing solutions to the challenge of storing electricity. See, for example, "How energy storage can change everything" by Daniel Burrus (http://www.huffingtonpost.com/daniel-burrus/how-energy-storage-can-ch_b_ 8010258.html) or "Innovation sputters in battle against climate change" by Eduardo Porter (http://www.nytimes . com/2015/07/22/business/energy-environment/innovation-to-stanch-climate-change-sputters.html).
} 
in cost savings, whereas innovation in storage improves the elasticity of substitution between renewable and conventional electricity production. Our main hypothesis is that better storage technologies promote innovation in both renewable and conventional electricity when the two production processes are substitutes.

To conduct our empirical analysis, we first build a global firm-level data set of electricity patents. We focus on Triadic patents, which are patents filed in all of the three major patent offices: the European Patent Office (EPO), the US Patent and Trademark Office (USPTO), and the Japanese Patent Office (JPO). In total, we identify 19,232 unique Triadic patent applications for electricity storage, 154,041 for conventional technologies, and 178,841 for renewable technologies. In addition to the patent data, we use data on energy prices and macroeconomic variables. Altogether, our data set covers 13,877 firms, across 79 countries, for a period from 1963 to 2011. Using this data set, we estimate a dynamic firm-level innovation model that allows current innovation in each technology to depend on past innovations in the three technologies.

Our empirical results show that the development of new storage technologies promotes innovations in both renewable and efficiency-improving conventional technologies. Specifically, an additional storage patent at the average firm two years ago, raises the probability to apply for patents today by $1.11 \%$ for renewable energy patents and a $0.66 \%$ for efficiency-improving fossil fuel patents. Furthermore, after we disaggregate patents into narrower categories, we find that an additional storage patent leads to a $1.15 \%$ higher probability to apply for a patent in intermittent renewable technologies, while we find no evidence for a statistically significant effect of storage on peak-power fossil fuel technologies. Hence, electricity storage not only benefits renewables by mitigating the intermittency problem, but also encourages the development of more efficient fossil-fuel technologies and affects the energy mix in conventional technologies. Therefore, electricity storage can enable full exploitation of the energy potential in intermittent renewables, as producers can simply produce as much electricity as the sun and the wind offer at all times, store it, and dispatch it to the grid when needed. In addition, storage technologies can create new arbitrage possibilities for conventional electricity producers, because storage enables them to produce at a fairly constant rate, thereby minimizing ramping and other costs, to store the electricity, and to dispatch it during peak periods. Although it has been widely argued that electricity storage is a key solution to reducing carbon emissions in the electricity sector, this is the first paper to provide evidence that better storage not only improves the potential for renewable technologies but also boosts the efficiency of the entire electricity sector. These results imply that while storage can strengthen the potential for reducing carbon emissions from the electricity sector, the mere existence of new storage technologies does not guarantee lower emissions. The overall effect on carbon emissions also depends on other factors, such as new installed storage capacity and the relative competitiveness of low-carbon energy sources.

In addition, our empirical analysis explores the incentives to innovate in electricity storage. 
First, our results show the existence of a positive feedback effect between innovation in storage and in renewable generation, as more past innovation in renewable technologies leads to more innovation in storage. In contrast, we find no evidence for such feedback between innovation in conventional technologies and in storage. These results suggest that innovation efforts directed toward renewable technologies can indirectly benefit storage technologies.

Finally, and in contrast to previous work, we find evidence for a negative impact of the coal price on innovation in the electricity sector, including on innovation in renewable generation. ${ }^{4}$ While this result might seem counterintuitive, note that until viable electricity storage options become available, intermittent renewable energy relies on conventional power plants for a buffer in balancing the grid. ${ }^{5}$ Furthermore, better electricity storage solutions will likely affect base-load and peak-load power plants differently. Base-load power plants, which are typically characterized by high fixed costs and low marginal costs, will become relatively more competitive as electricity storage reduces the need to ramp production. This emphasizes the importance and complexity of both carbon pricing and storage in reducing carbon emissions from the electricity sector both in the short run and long run.

Our study contributes to the literature studying energy prices, induced innovation, and economic growth (see e.g. Popp, 2002, 2004, 2006b; Acemoglu et al., 2016, 2013; Aghion et al., 2016). ${ }^{6}$ Our empirical analysis is methodologically related most closely to Aghion et al. (2016), who quantify firm-level incentives to direct technological innovations toward renewable technologies in the automobile industry. Instead, we focus on the electricity sector, and differentiate our work from theirs by explicitly analyzing the role of electricity storage in inducing innovation in electricity generation.

The remainder of the paper is organized as follows. In section 2, we introduce the analytical framework for our empirical analysis and present testable hypotheses. In section 3, we explain how we build our unique data set and present descriptive statistics. Section 4 describes our empirical strategy, and section 5 discusses our estimation results. Finally, section 6 concludes the paper. ${ }^{7}$

\footnotetext{
${ }^{4}$ This result is in line with Lazkano and Pham (2016) who evaluate the impact of different fossil fuel prices in electricity generation by disaggregating electricity generating technologies into coal, natural gas, oil, hydro, and renewables.

${ }^{5}$ Unless a clean option like hydropower is available to provide such buffer, further growth in renewable generation relies on conventional power.

${ }^{6}$ Acemoglu et al. (2012), Bovenberg and Smulders (1995, 1996), and Goulder and Schneider (1999) theoretically analyze directed technological change and the environment. In addition, there is an extensive empirical literature studying the incentives to innovate in the energy sector; see, for example, Buonanno et al. (2003); Popp (2002, 2005); Calel and Dechezleprêtre (2012); Dechezleprêtre and Glachant (2014); Gans (2012); Hassler et al. (2012), and Noailly and Smeets (2015).

${ }^{7}$ In addition, we provide an online appendix that includes more details on data construction and provides an extensive robustness analysis.
} 


\section{Analytical framework}

In this section, we introduce several hypotheses regarding the relationship between innovation in electricity storage and electricity generation to guide our empirical analysis. Our hypotheses are based on the framework of Acemoglu et al. (2012) and on Aghion et al. (2016), who use the directed technological change framework to study brown versus green innovation in the automobile industry. In addition to innovation in renewable and conventional technologies, we consider innovation in electricity storage, which we think of as affecting the elasticity of substitution between renewable and conventional technologies. ${ }^{8}$

Electricity generation comes from renewable and conventional resources. Renewable electricity generators have access to free inputs (wind and sun), whereas conventional electricity generators rely on costly fossil fuels. Electricity producers benefit from the development of better renewable and conventional generation technologies, as the use of different energy sources becomes more efficient. Hence, better generation technologies lower the cost per unit of electricity and thus increases the competitiveness of the generation technology.

We focus on the role of electricity storage because absent such storage, intermittent renewables imperfectly substitute conventional electricity generation (Joskoaw, 2011). ${ }^{9}$ Given the requirement that electricity supply must equal demand at all times to balance the grid, it is not feasible for intermittent renewable energy to contribute a large share of electricity to the grid. Absent storage, this would require a large overcapacity of renewables to ensure grid balance. Intermittent renewable electricity production relies on a buffer of conventional generation to balance the grid. Hence, limited storage solutions imply that conventional electricity generation is a complement to intermittent renewable energy. The development of better storage offers a solution to this problem by improving the substitutability between renewable and conventional electricity generation; this decouples the production of energy from its consumption. Hence, with electricity storage, renewable electricity production can overcome the intermittency problem and become a substitute for, rather than a complement to, conventional production.

Within such framework, the development of better electricity storage technologies provides two benefits to the electricity sector. First, it enables a higher share of renewable electricity generation because decoupling electricity production from consumption alleviates the intermittency issue. Second, electricity storage makes the electricity market more flexible, which also benefits conventional producers who can exploit arbitrage possibilities and reduce their ramping costs.

On this basis, we introduce three testable hypotheses relating to innovation in electricity storage and generation technologies.

\footnotetext{
${ }^{8}$ For a theoretical model that accounts for this issue, see Lazkano et al. (2016).

${ }^{9}$ Note that hydropower is a significant exception because hydropower producers have the ability to store energy for later dispatch. For example, Danish wind power production relies on Norwegian hydropower as a buffer. However, owing to the high utilization of available hydropower resources, little room is left for expansion, and consequently, further growth in renewable energy must come from other sources that are likely to be intermittent.
} 


\section{H1. Innovation in storage promotes innovation in both conventional and renewable generation.}

The first hypothesis explains the impact of better storage technologies on innovation when conventional and renewable electricity are substitutes. Innovation in storage increases the elasticity of substitution between conventional and renewable generation, which affects the production level directly in addition to enhancing the flexibility of the electricity market. This raises the potential payoff from developing better generation technologies, both conventional and renewable. Better storage technologies thus promote innovation in both types of generation technologies, not just in renewables.

H2. With relatively inefficient storage, better generation technologies promotes innovation in storage.

The second hypothesis relates the incentives to innovate in storage to innovation in electricity generation. When the two production technologies are not sufficiently close substitutes (i.e., relatively inefficient storage), better generation technologies strengthens the incentives to innovate in storage. As the two types of production become closer substitutes, the marginal value of better storage technologies falls, and the incentives to innovate in storage weaken. Thus, for a sufficiently high initial elasticity of substitution (storage technology), better generating technologies yield less storage innovation. Moreover, a higher initial elasticity of substitution leads to a larger payoff from further innovation in generation. This implies that, as the storage technology improves, innovation efforts shift from storage toward generation. This suggests that innovation in storage and in generation become substitutes.

H3. The impact of the fossil fuel price on innovation in renewable and storage technologies is positive.

The third hypothesis focuses on the relationship between fuel prices and innovation. If renewable and conventional production are substitutes, the fuel price has a positive effect on renewable innovation, while the innovation response for conventional and storage technologies depends on the level of the fuel price. When the two are complements, a higher fuel price induces firms to innovate more in conventional technologies while reducing their innovation in renewable generation and storage (Acemoglu et al., 2012). Our hypothesis presumes that conventional and renewable electricity are substitutes, which is motivated by recent empirical research (Gerlagh and van der Zwaan, 2004; Popp, 2006a; Papageorgiou et al., 2016, see e.g.).

Our discussion ignores many complexities of electricity markets, such as spillover effects in innovation, capital investments in power generation and storage, and the variability in demand and renewable electricity production over the day, week, and year. Our empirical analysis in the remainder of the paper accounts for these complexities. 


\section{Data}

Estimating the incentives to innovate requires firm-level data on current and past innovations, and energy prices. ${ }^{10}$ Our data set, which spans 49 years (1963-2011) and 79 countries, comes primarily from two sources: the OECD's patent database and the International Energy Agency (IEA). Table A.1 in Appendix A lists all data sources. We start by describing the selection of data before presenting descriptive statistics.

We use patent data to measure innovation, and construct our unique patent data set following Popp (2005) and Aghion et al. (2016). ${ }^{11}$ Following Aghion et al. (2016), we consider patent families from the OECD's Triadic Patent Database to account for the vast value differences in patents across firms and countries. A Triadic patent application involves an applicant filing for an invention at each of the three most important patent offices: the EPO, the USPTO, and the JPO. Triadic patents form a special type of patent family that protect the same idea across different countries. ${ }^{12}$ This implies that each patent application has an equivalent application at the EPO, the JPO, and the USPTO. Because Triadic patents are filed in all three of the main patent offices, they include only the highest valued patents. The Triadic patent families database provides a common worldwide measure of innovation that avoids the heterogeneity of individual patent office administrations (Popp, 2005).

At the time of filing, each patent is assigned one or more IPC codes, which describe the technology area that a patent aims to protect. We use these IPC codes to identify technologies related to electricity generation and storage.

For conventional electricity generation technologies, we use the patent classification list compiled by Lanzi et al. (2011). Table A.3, in the appendix, presents IPC codes for efficiency-improving fossil-fuel technologies, whereas Table A.4 lists general fossil-fuel based IPC codes. In addition to a broad definition, we analyze the subset of fossil fuel technologies that are used for peak power to complement renewables following the list compiled by Lazkano and Pham (2016). For renewable electricity generation technologies, we compile the list of classification codes directly from WIPO's

\footnotetext{
${ }^{10}$ There are several advantages of a firm-level analysis. The primary reason is that we can take advantage of more variance, such as in the types of technologies firms innovate, patenting history, firm size/type, and to which national policies firms are exposed.

${ }^{11}$ There are several advantages of using patents as a measure of innovation. First, patents measure innovation output close to the actual time of invention (Popp, 2005). In addition, each patent contains detailed information about its applicants and inventors, which is helpful in identifying who owns each patent.

${ }^{12} \mathrm{~A}$ patent family consists of patents in multiple countries designed to protect one invention by the same inventor. Furthermore, the OECD uses the concept of "extended families," which are designed to identify any possible links between patent documents (Martinez, 2010). This is advantageous because it provides the most comprehensive method of consolidating patents into distinct families, allowing us to include an extensive number of patented ideas and to minimize omissions. Furthermore, patent families correct for home bias, which occurs because domestic firms tend to register more patents than do international competitors. A direct implication of this bias is that patents filed domestically only may have a lower value than patents registered both domestically and internationally. Also, because the same invention registered in a different country will receive a different application number and may be classified under additional International Patent Classification (IPC) codes, the risk of counting the same invention more than once is high. We avoid such problems by using Triadic patents.
} 
Green IPC Inventory (see Table A.5 in the appendix). This list is more comprehensive than others previously used in the literature, and thus, our patent database covers a significantly broader range of technologies. ${ }^{13}$ In addition to this broad definition, we consider a narrower definition that only includes intermittent renewable technologies. Finally, we select electricity storage technologies using WIPO's Green Technology inventory (Table A.6). In total, our baseline data set includes 392,445 patent applications. Of these, 154,041 relate to conventional fossil-fuel technologies, 178,841 are for renewables, and 19,232 are for storage technologies.

Figure 1 shows the evolution of patent applications in the three technologies from 1963 to 2011. In the mid 1970s, we observe a sharp increase in electricity generation patenting. The evolution of conventional and renewable patents is correlated, but a strong increase in renewable patent applications occurred at the end of the 1990s, such that they surpassed conventional patents, until the early 2000s, when a sharp decline occurred. The large drop in patents at the end of the period is due to the legal delays of patents registered with the USPTO, which implies delays between the priority date and the publication date varying from 18 months to five years (Dernis and Khan, 2004). This means that appearing in the Triadic patent database can take up to five years from the time a patent is filed in all three patent offices. ${ }^{14}$ We address this truncation bias in section 5.5.

Having defined and selected patents for all three types of technologies, we assign each patent to its owner. As the Triadic database contains detailed information only for some applicants, we draw more comprehensive information from the OECD Harmonized Applicants Names (HAN) database, which matches applicants with company names from business registry data. With this, we are able to link patents to firms and individuals. Fortunately, the HAN database contains firm information for many patent applications in our sample. We synchronize the remaining applications using applicant information contained in the Triadic Patent Families database. This procedure allows us to match every patent with an applicant. However, it poses two difficulties.

First, applicant names in the Triadic Patent database contain a number of spelling, character, and name variations. For example, "3M Innovative Properties" and "3M Innovative Properties Co" would be incorrectly treated as separate firms in the absence of name harmonization. We harmonize firm names using algorithms and manual corrections to capture variations in spelling and to match firms correctly with their patents. A second harmonization challenge is that some patent applications have multiple inventors and applicants. In these cases, we accurately represent the ownership of each patent by assigning the ownership share of each patent to its corresponding firm.

\footnotetext{
${ }^{13}$ The most widely used list is perhaps the one compiled by Johnstone et al. (2010), which contains a subset of the IPC codes from WIPO's Green Technology inventory. Although we employ WIPO's complete list in our baseline estimations, we evaluate the robustness of our results using the classification codes by Johnstone et al. (2010). We present a comparison of these two classifications in Table A.7 in the appendix.

${ }^{14}$ This is a disadvantage of Triadic patent families. A patent shows up in the database, under its filing date, only after it has been granted. As a consequence, US patent grants may delay the completion of data on Triadic patent families by up to five years.
} 


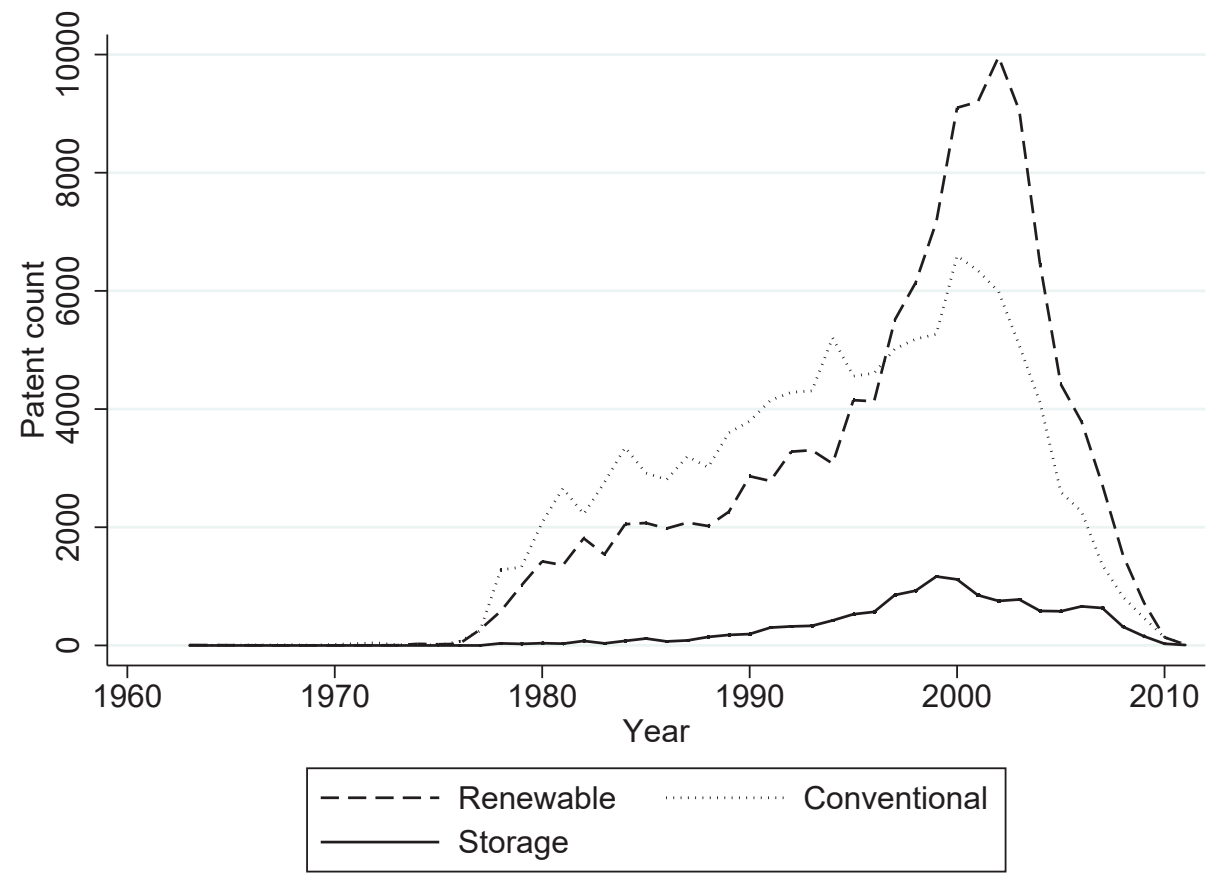

Figure 1: Global patenting over time.

Overall, our database contains 13,877 firms that claim residence in 79 countries. Of these firms, $4.54 \%$ are devoted exclusively to the advancement of storage technologies, whereas $26.94 \%$ and $51.44 \%$ focus only on conventional and renewable innovation, respectively. In addition, $11.27 \%$ of our sample firms innovate in both conventional and renewable electricity generation, whereas only $2.21 \%$ innovate in all types of technologies. The share of firms that innovate in renewable and storage technologies is $3.34 \%$, while the share that innovates in conventional and storage is $0.25 \% .{ }^{15}$ Most patenting firms are based in a few countries, and the biggest countries in terms of innovating firms are the US, Japan, Germany, France, and Great Britain. In the subsequent sections, in addition to conducting a global analysis using the full sample of 79 countries, we estimate our model using a subsample of data on these five countries that account for the majority of innovating firms and patents. Figure A.1 reports the number of firms per country, with more detail provided in the appendix, whereas Table A.2 lists all countries.

We combine the data into a firm-level panel containing the number of patent applications for each technology type and year between 1963 and 2011. As Figure 1 shows, patenting activity increases in the mid 1970s. For this reason, we use data for the period 1978-2009 in the estimations. Using data from 1963 to 2011, we create a set of variables to describe the extent of firms' past

\footnotetext{
${ }^{15}$ Because there are more firms that innovate in renewable technologies than in conventional, our data do not suggest that there are more synergies between storage and renewable technologies, than between storage and conventional technologies.
} 
innovations: pre-sample innovation history, internal and external knowledge stocks, and an indicator variable for active firms.

We create two variables to account for pre-sample innovation history following Blundell et al. (1995). Patent data reveals large heterogeneity in firms' innovation rates; while some firms make few innovations, others have a high innovation record, characterized by many patents. Using patent data from 1963 to 1977, we construct a research history variable to measure this permanent unobservable heterogeneity using the average number of patents each firm applied for in the presampling period. ${ }^{16}$ The second variable is an indicator of whether a firm innovated in the presample period. We use these variables to control for heterogeneity in size and propensity to patent of research firms.

In addition, we define a firm's existing knowledge stock in terms of internal and external past innovations following Aghion et al. (2016). The internal knowledge stock captures a firm's past innovations in a specific technology, which we calculate by accumulating the total number of patents in each technology type until year $t$. On the other hand, the external knowledge stock captures spillover effects, which are represented by past innovations in a given technology by all other firms in the relevant region. For each firm, we calculate this by adding the total number of patents in a region by all the other companies in that region in year $t$. We classify a firm's external knowledge stocks (spillovers) into eleven geographical regions based on the World Bank's income classification. The geographical regions are: Caucasian and Central Asia, Eastern Asia, Eastern Europe, Europe, Latin America and the Caribbean, Northern America, Oceania, South Eastern Asia, Southern Asia, Sub-Saharan Africa, and Western Asia. In our robustness analysis, we explore alternative definitions of spillover regions.

A final variable that captures past innovation is a dummy variable for firm activity. As only a small number of firms apply for patents every year, we utilize an unbalanced panel to proxy firms entering and exiting the market. We assume that a firm is active, and therefore included in our unbalanced panel, from the first year that it applies for a patent until the last year that it does so. ${ }^{17}$ For example, if a firm files for its first patent in 1981 and its last patent in 1995, we assume that this firm is active at least between 1981 and 1995.

Our third hypothesis describes the relationship between energy prices and innovation in the electricity sector. We include data on electricity input and output prices. ${ }^{18}$ We proxy fuel input

\footnotetext{
${ }^{16}$ We use the total number of patents a firm applies for before 1977 to calculate this pre-sample variable. Alternatively, we consider technology-specific pre-sample history and our results are robust to different definitions.

${ }^{17}$ We extend this period by including additional years at the beginning of the active period when considering different lag structures in our estimations. We return to this issue when we present our empirical analysis below.

${ }^{18}$ We draw end-use energy price and tax data in U.S. dollars from the International Energy Agency's energy price and tax database. Unfortunately, energy ex-tax data on end-use are only available for a small number of countries. Instead, we employ end-use total price data expressed in U.S. dollars converted using average exchange rates per energy unit, and tonnes of oil equivalent in U.S. dollars converted using annual purchasing power parities (PPPs) per energy unit. The detailed construction of these data can be found in the IEA's energy prices and taxes database documentation.
} 
prices with coal, natural gas, and oil prices, and we use electricity retail prices to proxy for the output price. We draw country-level data from the IEA's database of energy prices and taxes (IEA, 2014). All prices are in 2005 US dollars per ton of oil equivalent net calorific value (USD/toe NCV). Unfortunately, complete energy price series are only available for 33 out of the 79 countries in our patent data set. In appendix A.iii, we explain how we complete our energy price data set. ${ }^{19}$

In addition to energy price and tax data, we collect data on other country-level policies that affect innovation. Specifically, we use data on public research and development subsidies for the energy sector from the IEA Energy Technology RD\&D Statistics. Data are only available for 26 countries. ${ }^{20} \mathrm{R} \& \mathrm{D}$ data are in 2005 U.S. dollars and we separate them by technology type: storage technologies, renewable technologies, efficiency-improving fossil-fuel technologies and general fossilfuel technologies.

A final set of explanatory variables controls for cross-country differences in the size of an economy using real GDP data, while we control for wealth with real GDP per capita. With these two variables, our goal is to capture the differences in a country's size among equally wealthy countries. ${ }^{21}$ We also control for population density as there is evidence of higher innovation rates in areas with higher employment density (Carlino et al., 2007). We draw GDP and population data from the Penn World Tables (Feenstra et al., 2013) and population density data from the World Development Indicators. GDP is measured in millions of 2005 U.S. dollars, population is measured in millions of people, and population density in people per square kilometer of land area.

Finally, we identify the location of each firm. Some firms are active in more than one country and are thus affected by the regulations, taxes, and macroeconomic indicators of several countries. To account for this, we construct firm-specific variables for energy prices, research subsidies and economic indicators by calculating the averages for these variables across all countries in which a firm is present. For firms that are only active in one country, firm prices and economic variables are identical to the respective country-level variables. Firm-level variation in energy prices and macroeconomic indicators is useful, as it allows us to use country fixed effects to control for countrylevel variation. ${ }^{22}$

\footnotetext{
${ }^{19} \mathrm{As}$ we rely on price indices to complete our energy price data set, it could be argued that our approach reduces the variation in our data set. Note, however, that the largest countries in terms of electricity-related patents are all part of the OECD, which means that we have a complete or nearly complete set of energy price series for the most innovative countries. Similarly, countries for which we make the strongest assumptions about energy prices (e.g., countries in Africa) are countries in which little patenting takes place. Therefore, we have accurate energy prices for the vast majority of innovating firms in our data set and for all firms in the five-country subsample.

${ }^{20}$ The countries we have data for are: Australia, Austria, Belgium, Canada, Czech Republic, Denmark, Finland, France, Germany, Greece, Hungary, Ireland, Italy, Japan, Korea, Luxembourg, Netherlands, New Zealand, Norway, Portugal, Spain, Sweden, Switzerland, Turkey, United Kingdom, United States of America.

${ }^{21}$ For example, the United States and Switzerland are among the wealthiest nations, with mean GDP per capita above USD 33,000 over our sampling period. However, in terms of total GDP the two countries are different; over our sampling period, the US has an average GDP of USD 9,324 billions, while Switzerland's average GDP is USD 248 billions. The overall correlation during the sampling period is: $22.41 \%$ between GDP and GDP per capita, $-19.8 \%$ between GDP and population density, and $15.8 \%$ between population GDP per capita and population density.

${ }^{22}$ As each firm can be active in several countries, we can include both country and firm fixed effects.
} 
To summarize, the data set accounts for the most valuable electricity-related patents, and these patents capture the global trends in innovation in the electricity sector.

\section{Empirical strategy}

This section describes our econometric approach to identify the role of electricity storage for firmlevel innovation in electricity generation technologies. In section 2, we presented several hypothesis regarding the determinants of innovation in the electricity sector. Empirically, we analyze these drivers of innovation using a dynamic nonlinear model with fixed effects that allows current patent applications $y_{j, i t}$ to depend on past patent applications $y_{j, i t-k}$ for firm $i$ 's innovation in technology $j$ in year $t$.

In particular, our baseline specification follows Cameron and Trivedi (2013), which with $k$ lags is:

$$
\mathbb{E}\left[y_{j, i t} \mid \mathbf{X}_{\mathbf{j}, \mathbf{i t}}, \mathbf{Y}_{\mathbf{j}, \mathbf{i t}-\mathbf{k}}, \alpha_{j, i}\right]=\alpha_{j, i} \lambda_{j, i}
$$

where $\mathbf{X}_{\mathbf{j}, \mathbf{i t}}=\left(\mathbf{x}_{\mathbf{j}, \mathbf{i t}}, \mathbf{x}_{\mathbf{j}, \mathbf{i t}-\mathbf{1}}, \ldots, \mathbf{x}_{\mathbf{j}, \mathbf{i 1}}\right)$ are observable variables, $\mathbf{Y}_{\mathbf{j}, \mathbf{i t}-\mathbf{k}}=\left(y_{j, i t-k}, \ldots, y_{j, i 1}\right)$ is a vector of the $k$ past innovations, $\alpha_{j, i}$ captures individual technology-specific fixed effects, and $\lambda_{j, i}$ is the specified function of $y_{j, i t-k}, \mathbf{x}_{\mathbf{j}, \mathbf{i}}$, and $\boldsymbol{\beta}$. The estimation of equation (1) possesses several challenges. One challenge is to choose the functional specification for how $y_{j, i t-k}$ enters (1). We use an exponential feedback model that allows past innovations to affect current innovations following Blundell et al. (2002). This approach avoids discontinuities when dealing with patent data with a wide range of counts. Specifically, in our baseline specification of (1), we use: $\mathbb{E}\left[y_{j, i t} \mid \mathbf{X}_{\mathbf{j}, \mathbf{i t}}, \mathbf{Y}_{\mathbf{j}, \mathbf{i t}-\mathbf{k}}, \alpha_{j, i}\right]=\alpha_{j, i} \exp \left(\rho y_{j, i t-k}+\mathbf{x}_{\mathbf{j}, \mathbf{i t}}^{\prime} \boldsymbol{\beta}\right)$. Another challenge is to obtain consistent estimates in the presence of fixed effects. We deal with this issue by controlling for firm-level unobserved heterogeneity using patenting in the pre-sampling period following Blundell et al. (1995, 1999). Thus, for firm $i$ 's innovation in technology $j$ in year $t$, we estimate:

$$
y_{j, i t}=\exp \left(A_{j, i t-2}+\ln \mathbf{P}_{i t-1} \boldsymbol{\alpha}_{\boldsymbol{j}}+\ln \mathbf{Z}_{i t-1} \boldsymbol{\gamma}_{\boldsymbol{j}}+\rho_{1} \ln H_{j, i t}+\rho_{2} I D_{i t}+\delta_{n t}\right) \delta_{j, i}+u_{j, i t},
$$

where $j$ denotes the type of technology ( $s$ storage, $c$ conventional, and $r$ renewable), and where $i$, $n$, and $t$ represent firm, country, and year. Recall that $y_{j, i t}$ is the number of patents in technology $j$ that firm $i$ applies for in year $t .^{23} A_{j, i t}$ is the firm's existing knowledge stock, which we define in terms of internal and external past innovations, following Aghion et al. (2016).

We specify past innovation as a nonlinear relationship between innovation and existing knowl-

\footnotetext{
${ }^{23}$ As noted by a referee, our specification might not fully capture that innovation happens in jumps caused by major breakthroughs. We proxy improvements in technology by the number of patents submitted by firms and therefore cannot control for the impact of each innovation. An alternative is to use a quality-adjusted measure of patents based on citation data. Unfortunately we are unable to do this because citation data are only available for some but not all patent offices from 1978 to 2001, while our data covers all applications from 1963 to 2011.
} 
edge:

$$
A_{j, i t}=\mathbf{I}_{i t} \boldsymbol{\beta}_{\mathbf{2 j}}+\mathbf{I}_{i t}^{2} \boldsymbol{\beta}_{\mathbf{3 j}}+\mathbf{E}_{m i t} \boldsymbol{\beta}_{\mathbf{1 j}},
$$

where the internal knowledge vector $\mathbf{I}_{i t}$ is firm $i$ 's stock of patents in different technology types in year $t$, whereas the external knowledge vector $\mathbf{E}_{\text {mit }}$ represents the total number of patents across all firms minus firm $i$ in firm $i$ 's region $m$ at time $t$ for each technology $j .{ }^{24}$

Another main determinant of innovation is energy prices. $\mathbf{P}_{i t}$ indicates a firm's exposure to energy prices in year $t$. We take into account the prices of both inputs and outputs in the electricity sector. Our baseline specification uses the coal price as the proxy for input prices in conventional electricity generation, and electricity prices as the proxy for output prices. We consider other energy prices, as well as environmental policies in the robustness section. In addition, our empirical model accounts for additional factors that may affect innovation, including the economic environment of the countries in which the firm is located. Specifically, $\mathbf{Z}_{i t}$ is a vector that captures the firm-specific exposure to the economic environment, which we characterize by the economy's size (proxied by GDP), wealth (proxied by GDP per capita), and population density. As explained in section 3, we calculate $\mathbf{P}_{i t}$ and $\mathbf{Z}_{i t}$ for each firm by calculating the average for each of the energy prices and economic indicators across all countries in which firm $i$ is located. This captures multinational firms' exposure to energy prices and macroeconomic conditions in all countries in which they operate.

In addition to including explanatory variables, we capture permanent unobservable differences across firms using information on firms' patenting history in the pre-sampling period following Blundell et al. $(1995,1999)$. Taking advantage of our extended patent data set, we include the average pre-sample patent count $\left(H_{j, i t}\right)$ for each firm and technology type and an indicator variable $\left(I D_{i t}\right)$, which equals 1 if the firm ever innovated in the pre-sample period (1963-1977).

We control for year, firm- and country-specific characteristics using a set of fixed effects. ${ }^{25}$ Specifically, $\delta_{j, i}, \delta_{n}$, and $\delta_{t}$ denote firm, country, and year fixed effects. As all country-level variables, including energy prices and macroeconomic variables, are firm specific by construction, we include country and year fixed effects to control for other unobserved characteristics. Our extensive panel data set requires a large number of fixed effects to control for firm-level, country-level and year characteristics. The many fixed effects suggest the existence of incidental parameters, which presents a challenge to obtain consistent maximum likelihood estimates. ${ }^{26}$ Specifically, we

\footnotetext{
${ }^{24}$ Robustness analysis shows that squared terms of external knowledge stocks are insignificant, and therefore, we exclude them from the baseline specification.

${ }^{25}$ These fixed effects control for differences in electricity markets and innovation and energy policies across countries, differences in firm sizes, industry focus, and many other characteristics. Both innovation efforts and the number of patent applications may change over time in response to both the firms' and the relevant country's idiosyncrasies, and the volatile nature of the industries. The country-year fixed effects control for all time-varying country-specific factors, including environmental policies, innovation incentives, or changes in the way that patents are granted.

${ }^{26}$ Blundell et al. (1999) and Lancaster (2002) show that a linear Poisson maximum likelihood model has no incidental problem in parameters. However, since our model is both dynamic and nonlinear, following Blundell et al. (1999) and Lancaster (2002) we reparametrize the fixed effects to avoid a potential incidental parameter problem in the maximum likelihood estimates.
} 
include firm and year fixed effects in the full-sample estimations, whereas the estimations for the five-country subsample include the full set of fixed effects, which includes fixed effects to control for firm-level characteristics, and dummy variables to control for country-level characteristics and year. With this reparametrization, the maximum likelihood estimation provides consistent estimates even if there are incidental parameters. ${ }^{27}$

Finally, $u_{j, i t}$ denotes the technology-specific error term. Since our patent data are aggregated at the firm level for each technology type, we cluster standard errors at the firm level for each technology. There are additional correlations in the data because we average prices and macroeconomic variables across countries for international firms. Since these data are not nested, we include fixed effects in one dimension and cluster in the other dimension (Thompson, 2011). Specifically, we create a country dummy variable that controls for country-fixed effects and cluster the errors at the firm level. As discussed above, we try to limit the number of country dummies to avoid incidental parameter problems, and we thus control for international firms by a dummy that equals one for all international firms instead of creating a dummy for each combination of collaborative countries.

To account for the possibility of firms entering and exiting the research sector, we only include data for years in which firms are defined as active, as explained in section 3. We relax this assumption in section 5.5. Also, to reflect adequately the delayed patenting response of firms to changes in innovation drivers, and to reduce contemporaneous feedback effects, we lag the knowledge stock variables by two periods and the rest of the explanatory variables by one period in our baseline model. We consider alternative lag structures in the caveats section.

We estimate the nonlinear count data model in equation (2) using a fixed-effects Poisson estimator with pre-sampling history (Hausman et al., 1984; Blundell et al., 1995, 2002). We estimate the innovation equation for each technology separately. ${ }^{28}$ Note that the consistent estimation of parameters is generally a challenge in nonlinear fixed effects models because of the need to control for a large number of fixed effects, often with short panels. While our panel data spans 48 years, a large number of distinct research firms located in multiple countries means that we must control for many fixed effects. As shown by Cameron and Trivedi (2013), there are three approaches for obtaining consistent estimates of our nonlinear fixed effects model, and since the FE Poisson model

\footnotetext{
${ }^{27}$ To make sure our main results are not affected by incidental parameter problems, we reparametrize the model with trend to control for year effects in table B.22. These results show that our key parameters of interest are not significantly different from our baseline results, but the standard errors of other coefficients become smaller.

${ }^{28}$ We estimate each equation separately rather than jointly to ensure that our maximum likelihood estimations converge. Estimating the three equations jointly would allows us to increase the efficiency (see e.g. King, 1989). Finding significant effects when estimating the equation system separately, thus strengthens rather than weakens the results.
} 
leads to consistent estimation of parameters in all three cases, we use this estimator. ${ }^{29,30}$ We return to alternative estimators in the caveats section.

Our identification strategy, based on equation (2), attributes any differences in a firm's patent applications in a specific technology to be caused by differences in internal and external knowledge stocks and energy prices, after controlling for macroeconomic factors, as well as country and firmspecific time-varying heterogeneity. Using the above econometric model, we empirically study the firm-level determinants of innovation in the electricity sector and the role of electricity storage in innovation. We discuss the main empirical results in the next section.

\section{Empirical results}

In this section, we present our main estimation results, followed by multiple robustness tests to validate our results. We test three hypotheses. First, how do better storage technologies affect innovation in electricity generation? Next, how does innovation in electricity generation affect innovation in storage? And finally, what is the impact of fossil-fuel prices on innovation? To answer these questions, we estimate equation (2) as described in section 4 .

We present our baseline estimates in Tables 1 and 2. Table 1 reports the marginal effects of the FE Poisson estimates of our baseline specification (eq. 2), using data from 1978 to $2009{ }^{31}$ Columns (1)-(3) use data from the full sample of 79 countries, controlling for firm and year fixed effects, whereas columns (4)-(6) report the results for the five most innovative countries and control for firm, year, and country fixed effects. We estimate the model with the complete fixed-effects specification for the subsample of firms in the five most innovative countries. Table 2 presents these results. ${ }^{32}$

There are no statistically significant differences in key coefficients across the three fixed-effects specifications reported in Table 2 for the five-country subsample. This suggests that our full-

\footnotetext{
${ }^{29}$ The three approaches for obtaining consistent estimates are: (1) To use a moment-based estimator that eliminates fixed effects. The Poisson fixed effects estimator is the method of moments estimator and provides consistent estimates when regressors are strictly exogenous. (2) To estimate both $\beta$ and fixed effects jointly by maximum likelihood. The simplest parametric fixed effects model for count data is the Poisson fixed effects model. The maximum likelihood estimation treats the fixed effects as parameters to be estimated jointly with the other model parameters. (3) Maximum likelihood estimation of the parameters conditional on sufficient statistics for the individual effects. This is the case for the Poisson fixed effects model.

${ }^{30}$ One could argue that in our dynamic model with lagged dependent variables, the strict exogeneity of regressors is a strong assumption. If regressors are only weakly exogenous, which implies that future shocks are uncorrelated with current regressors, we can consider predetermined regressors that are correlated with past shocks, while still being uncorrelated with current and future shocks. In this case, the Poisson fixed effects estimator is inconsistent. A solution could be to use GMM estimation by eliminating fixed effects with a transformation. However, Blundell et al. (1995) show that the precision of this estimator is poor when the transformed regressors are persistent, which is the case with patent data. We therefore use an alternative Poisson FE estimator that controls for pre-sample history of research firms instead of using a GMM regressor.

${ }^{31}$ We evaluate marginal effects at mean levels of the variables.

${ }^{32}$ Note that the fixed-effects specification reported for the five-country sample in Table 1 is identical to that in column (2) of Table 2.
} 
sample estimates, which only control for firm and year fixed effects, are reliable. Adding country fixed effects to the basic specification with only firm and year fixed effects has little or no effect on the coefficient estimates and their standard errors. Adding year-by-country fixed effects tend to increase the absolute value of the coefficient estimates slightly, but it also increases the standard errors. Finally, in Table 3 we restrict our attention to intermittent renewable technologies and peak-power fossil fuel technologies.

In the caveats section (5.5) and in appendix B, we present an extensive robustness analysis to validate our results. Overall, our robustness results show that the marginal effects reported in Tables 1 and 2 are highly robust to a variety of different specifications and subsamples of the data. We consistently find that past innovation in electricity storage promotes innovation in both renewable and conventional electricity generation technologies. This implies that storage is critical, not only to solve the intermittency problem of renewable electricity generation, but also to enhance conventional generation. We discuss our results in more detail below.

\subsection{How do better storage technologies affect innovation in electricity generation?}

To investigate the role of storage in electricity generation, we analyze the impact of internal and external storage knowledge stocks on the firm-level probability of applying for a new patent in electricity generation. In this case, we are interested in the coefficient estimates for the internal and external L2.Storage variables. ${ }^{33}$

As seen in the first rows of Tables 1 and 2, one additional internal storage patent increases the firm-level probability of applying for a new patent in electricity generation. Specifically, the coefficient estimate for the internal storage variable for the global sample, 0.0111, is statistically significant at the $1 \%$ level (renewable column of Table 1). The estimate indicates that if the average firm had an additional storage patent two years ago, the probability that the firm files for a renewable patent today increases with $1.11 \%$. We obtain the same point estimate using data on the five most innovative countries. This positive effect of storage on innovation in renewables is expected, as storing electricity is considered to be key to mitigating the intermittency problem of renewable electricity generation.

Similarly, the internal knowledge stock variable for storage indicates that having one more storage patent increases the probability that the average firm applies for an efficiency-improving conventional patent by $0.66 \%$ (conventional column of Table 1 ). The corresponding marginal effect of an additional storage patent for the five-country sample is $0.75 \%$, also statistically significant at the $5 \%$ level. Hence, our results show that more internal storage knowledge increases innovation in both renewable and conventional technologies. In addition, we show that more past innovation in storage no longer has a statistically significant effect on innovation in conventional technologies if

\footnotetext{
${ }^{33}$ Note that L2 refers to the number of lags of the variable, which in the case of knowledge stocks is two.
} 
we include both general fossil-fuel technologies and efficiency-improving technologies (Table B.ii in the appendix). This indicates that better storage solutions primarily benefit efficiency-improving conventional technologies and that more innovation in storage can steer innovation in conventional generation toward improved efficiency. One reason for this is that electricity storage allows thermal power plants to reduce their ramping costs, which enhances the importance of efficiency in production.

We investigate this further by focusing on a narrower definition of renewable and conventional technologies. Specifically, in Table 3 we only include intermittent renewable energy patents and peak-power fossil-fuel generation technologies. ${ }^{34}$ Table 3 shows that an additional storage patent two years ago increases by $1.15 \%$ the probability to apply for an intermittent renewable patent today. Our main results are robust, but while the coefficient capturing the effect of storage on fossil fuel is still positive, this effect is no longer statistically significant. We do not find this result surprising as storage is a substitute for conventional peak-power plants.

Having looked at the effects of internal knowledge in storage technologies, we consider the external knowledge (spillover) effects. We find that more external storage knowledge has a positive effect on innovation in renewable generation. This finding is statistically significant at the $10 \%$ level for the full sample but is not significant for the five-country subsample, regardless of fixedeffects specification. ${ }^{35}$ The corresponding estimates for conventional generation are negative but not significant.

To conclude, our empirical results show that the development of storage technologies promotes innovation in both renewable and efficiency-improving conventional technologies. These results are in line with our first hypothesis and they are robust to a variety of different specifications, as we discuss in section 5.5 and in our robustness appendix B. These results imply that innovation efforts directed at the development of better storage technologies can give renewable electricity a boost by mitigating the intermittency problem. However, whether in fact storage will increase the share of

\footnotetext{
${ }^{34}$ Since waste and biomass technologies can sometimes be storable, we exclude all patents related to waste and biomass from renewable technologies to concentrate on intermittent energy sources. The classification of conventional technologies is far more challenging. Following Lazkano and Pham (2016), peak-power fossil-fuel technologies include gas turbines, compression-ignition engines and co-generation, and as seen at the bottom of the table, narrowing the definition of conventional technologies to peak-load generation severely reduces the number of observations. Note that it is not straightforward to distinguish between technologies in such way. First, the classification of peak-load and base-load technologies is sometimes based on the flexibility with which one can ramp production up and down, and sometimes on whether one uses the technology to generate electricity during peak hours and/or off-peak. In many cases, the two classification methods yield the same result, but not always. For the purpose of our analysis, it is primarily the flexibility to ramp production up and down that matters. Second, electricity generating technologies are location and time specific. Finally, many of the available electricity generation technologies, regardless of whether they are peak-load, base-load, conventional or renewable, draw on the same core technologies and components. The turbine in the hydropower example illustrates this; turbines are critical components in gas- and coal-fired power plants (peak- and base-load conventional), hydropower, and wind power plants (intermittent renewables). Given this technological overlap across generation methods, it is challenging to exclusively provide a detailed classification of generation technologies into peak-load and base-load renewable and conventional generation.

${ }^{35}$ The small standard errors on the coefficient estimates for the external knowledge stocks in our estimation tables could be caused by multicolinearity since $82.94 \%$ of firms exclusively patent in one technology type.
} 
renewable electricity depends on its competitiveness in comparison with more efficient conventional electricity production, which gains from efficiency-improving innovations and lower ramping costs with storage.

\subsection{How does innovation in electricity generation affect technological advance- ments in storage?}

Next, we analyze the feedback effect of better electricity generation technologies on innovation in storage. Tables 1 and 2 show that having an additional renewable energy patent promotes new innovation in storage technologies, although it may have a negative effect on innovation in storage in other firms in the region (negative spillovers). This result holds for the full sample and across the different fixed-effects specifications for the five-country sample. However, the coefficient capturing the external effect becomes smaller, and its standard error increases, as we control for more fixed effects. Therefore, we conclude that a greater level of innovation in the past in renewable generation has a positive effect on innovation in storage overall.

Although we find a positive feedback effect between innovation in storage and innovation in renewable generation, we find no evidence for such feedback between innovation in storage and innovation in conventional generation. ${ }^{36}$ On the contrary, more past innovation in efficiency-improving conventional generation has a negative but insignificant effect on innovation in storage, both within the firm and externally (spillover effects). However, once we restrict our attention to peak-power technologies, Table 3 shows that past innovation in storage has a positive, yet insignificant, effect on storage innovation. The effects of both internal and external generation knowledge stocks on storage are robust to all four definitions of regions for knowledge spillovers (see Appendix B.vi), and a variety of other specifications, as presented in the robustness analysis in the appendix.

Finally, an additional internal storage patent lowers a firm's probability of filing for another storage patent. This result is in line with our theoretical prediction, and is consistent across a number of different specifications and subsamples (see, for example, Tables 1 and 2, and Appendices B.v and B.vi). However, the results are largely insignificant for the effect of external storage knowledge stocks on innovation in storage.

To summarize, we find the existence of a positive feedback effect between innovation in renewable generation and storage technologies, but our results suggest no such feedback between conventional (neither efficiency-improving nor peak-power) technologies and storage. This implies that more past innovation in renewable technologies stimulates innovation in storage technologies and vice versa.

\footnotetext{
${ }^{36} \mathrm{~A}$ potential reason for only finding a positive feedback between technologies for storage and renewable generation is that significant growth in renewable energy requires increased use of intermittent renewable energy sources, which relies critically on energy storage. In contrast, conventional fuels are self-sufficient in terms of balancing the grid. This result is robust also if we focus primarily on base-load conventional technologies. In fact, the estimated negative effect of better conventional technologies on innovation in storage becomes significant if we estimate the model excluding data on key peak-power technologies.
} 
Thus, policy efforts directed toward renewable technologies can indirectly promote the advancement of storage technologies, which in turn further promote innovation in renewable technologies.

\subsection{How does the fossil-fuel price affect innovation?}

Finally, we analyze the impact of fossil-fuel prices on innovation in the electricity sector and, particularly, their impact on the direction of innovation (renewable versus conventional). As our baseline specification uses coal prices as a proxy for the fuel price, we focus on the effect of the coal price. ${ }^{37}$ Many economists argue in favor of taxing carbon emissions to make fossil fuels more expensive and, thus, to induce a shift from carbon-emitting fossil fuels to cleaner renewable energy sources. This motivates our analysis of how the fuel price affects innovation.

Our results show that a higher coal price reduces innovation in electricity generation and in storage. The negative effects of the coal price on innovation in conventional and storage technologies are in line with our third hypothesis, which presumes that renewable and conventional electricity production are substitutes. The finding that the coal price is a determinant of innovation in conventional electricity generation is also consistent with the results of previous work (see e.g. Popp, 2002; Aghion et al., 2016; Noailly and Smeets, 2015; Lazkano and Pham, 2016). However, the statistically significant negative impact of the coal price on innovation in renewable technologies suggests that conventional production represents a complement to renewable production. ${ }^{38}$

Our empirical analysis accounts for a number of different renewable and conventional generation technologies. Some of these are better suited to providing base-load power, whereas others are better suited to providing peak-load power. Base-load power plants run 24 hours a day, whereas peak-load plants run only when demand is high. Furthermore, base-load electricity typically have high fixed costs but low unit costs of production, which makes ramping production up and down costly. These plants are also less flexible, as they need a longer time to adjust production. In contrast, peak plants are both quicker and cheaper to ramp up and down. These plants are turned on and off frequently, and they require periods of downtime. Among the conventional electricity sources, we have a full suite of both peak-load and base-load options for electricity production. For example, thermal coal-fired power plants might provide base-load power, whereas natural-gas-fired peaker plants provide peak-load power. Intermittent renewable energy plants are neither base-load nor peak-load power plants; they can provide both base-load and peak-load power, but to ensure reliability of supply in the absence of efficient electricity storage solutions, these energy sources must be combined with conventional sources to ensure sufficient base-load and peak-load electricity production. ${ }^{39}$

\footnotetext{
${ }^{37}$ In section 5.5, we consider the alternative fuel prices natural gas and oil.

${ }^{38}$ This finding contrasts other recent studies, such as Aghion et al. (2016) who find that firms innovate more in clean technologies in the automobile sector when they face higher fuel prices. Our results, however, are in line with Lazkano and Pham (2016) who find evidence for a negative impact of coal prices in the development of renewable technologies in the electricity sector.

${ }^{39}$ Alternatively, one could supply only renewable electricity, but this would require large investments in renewable
} 
The different types of both renewable and conventional production facilities can be substitutes for, or complements to, each other. In general, peak-load plants complement base-load plants. Hence, a natural gas peaker plant complements a coal-fired thermal power plant, but it might also complement intermittent renewable production. Therefore, depending on the efficiency of the electricity storage solution, we might find that for renewable electricity production, conventional electricity is a complement that acts as a buffer, whereas for conventional production as a whole, renewable electricity production is a substitute.

This brings us back to the seemingly odd result that the fossil fuel price has a negative impact on innovation in renewable electricity generation, which suggests that renewable and conventional electricity are complements. In light of the above discussion, we can explain this if conventional production is a complement for renewable production, as suggested by the negative impact of the fuel price on renewable innovation, whereas for the complete suite of conventional production alternatives, renewable electricity is a substitute. Thus, for the time being, a higher fuel price hurts innovation in both conventional and renewable generation. In addition, given the positive feedback effect between innovation in renewable and storage technologies, less innovation in renewable technologies resulting from a higher fuel price indirectly discourages innovation in storage, which in turn affects renewable innovation. Hence, until more efficient electricity storage solutions exist, taxing fossil fuels is unlikely to boost innovation in renewable and storage technologies, unless one combines such a policy with other instruments that stimulate innovation in these technologies.

Finally, note that electricity storage can increase the competitiveness of base-load coal-fired power plants by reducing their ramping problem as well as reducing the intermittency issue of renewables. This implies that once the ability to store electricity at a large scale increases, carbon pricing and other policies can induce a transition from carbon-intensive coal-fired electricity generation toward cleaner energy sources.

\subsection{Other determinants}

In addition to past innovation and fuel prices, we control for country size (proxied by GDP), wealth (proxied by GDP per capita), and population density. Our results show that higher GDP has a negative impact on the probability of applying for a conventional electricity generation patent, whereas the wealth of a country and population density promote innovation in renewable technologies. These effects are robust to different model specifications using the full global sample. When we focus on the most innovative countries, higher GDP discourages innovation in both renewable and conventional electricity generation, whereas wealth and population density discourage innovation in electricity storage (Table 2). We do not find this surprising as the most innovative countries exhibit less variation in population density and GDP per capita than countries in the full data set.

electricity generation capacity to ensure sufficient production at all times to balance the grid on and off peak. However, this will change as better solutions for storing electricity become available. 
Table 1: Baseline estimates for all countries and top-five innovative countries (marginal effects).

\begin{tabular}{|c|c|c|c|c|c|c|}
\hline & \multicolumn{6}{|c|}{ Dependent variable: firm-level patents } \\
\hline & \multicolumn{3}{|c|}{ All countries } & \multicolumn{3}{|c|}{ Top five countries } \\
\hline & Renewable & Conventional & Storage & Renewable & Conventional & Storage \\
\hline \multicolumn{7}{|c|}{ Internal knowledge (marginal effects): } \\
\hline \multirow[t]{2}{*}{ L2.Storage } & $.01116^{* * *}$ & $.00781^{* *}$ & $-.00749^{* *}$ & $.01114^{* * *}$ & $.00648^{* *}$ & $-.00677^{* *}$ \\
\hline & $(.00376)$ & $(.00327)$ & $(.00295)$ & $(.00398)$ & $(.00365)$ & $(.00265)$ \\
\hline \multirow[t]{2}{*}{ L2.Renewable } & $-.00188^{* *}$ & -.00048 & $.00188^{* * *}$ & $-.00171^{* *}$ & .00061 & $.00182^{* * *}$ \\
\hline & $(.00076)$ & $(.00163)$ & $(.00053)$ & $(.00078)$ & $(.00141)$ & $(.00057)$ \\
\hline \multirow[t]{2}{*}{ L2.Conventional } & -.00376 & .00083 & -.00036 & -.00403 & -.00137 & $-3.1 \mathrm{e}-05$ \\
\hline & $(.00253)$ & $(.00208)$ & $(.00567)$ & $(.00267)$ & $(.00217)$ & $(.00562)$ \\
\hline \multicolumn{7}{|l|}{ External knowledge: } \\
\hline \multirow[t]{2}{*}{ L2.Storage } & $.00032^{* *}$ & -.00029 & .00019 & $.00028^{* *}$ & -.00035 & -.00014 \\
\hline & $(.00013)$ & $(.00022)$ & $(.00016)$ & $(.00014)$ & $(.00021)$ & $(.00015)$ \\
\hline \multirow[t]{2}{*}{ L2.Renewable } & $-8.9 \mathrm{e}-05^{* * *}$ & $3.4 \mathrm{e}-05$ & $-3.4 \mathrm{e}-05$ & $-9.4 \mathrm{e}-05^{* * *}$ & $2.8 \mathrm{e}-05$ & $2.3 \mathrm{e}-05$ \\
\hline & $(2.2 \mathrm{e}-05)$ & $(4.7 \mathrm{e}-05)$ & $(3.2 \mathrm{e}-05)$ & $(2.7 \mathrm{e}-05)$ & $(5.3 \mathrm{e}-05)$ & $(2.9 \mathrm{e}-05)$ \\
\hline \multirow[t]{2}{*}{ L2.Conventional } & $4.8 \mathrm{e}-05$ & -.00017 & $-9.5 \mathrm{e}-06$ & $5.2 \mathrm{e}-05$ & $-.00026^{* *}$ & -.00016 \\
\hline & $(5.1 \mathrm{e}-05)$ & $(.00011)$ & $(9.2 \mathrm{e}-05)$ & $(6.4 \mathrm{e}-05)$ & $(.00012)$ & $(.0001)$ \\
\hline \multicolumn{7}{|l|}{ Energy prices (firm level): } \\
\hline \multirow[t]{2}{*}{ L1.Coal } & $-.3377^{* *}$ & $-.7816^{* * *}$ & $-.3552^{*}$ & $-.3552^{*}$ & $-.8601^{* * *}$ & -.215 \\
\hline & $(.1477)$ & $(.1731)$ & $(.2327)$ & $(.1903)$ & $(.2193)$ & $(.3109)$ \\
\hline \multirow[t]{2}{*}{ L1.Electricity } & .08147 & .284 & .2223 & .08337 & $.512^{*}$ & .4641 \\
\hline & $(.2103)$ & $(.219)$ & $(.2584)$ & $(.2529)$ & $(.307)$ & $(.3603)$ \\
\hline \multicolumn{7}{|c|}{ Economic controls (firm level): } \\
\hline \multirow[t]{2}{*}{ L1.GDP } & $-.187^{* *}$ & -.1344 & .04179 & $-.1802^{*}$ & $-.2925^{* *}$ & .1963 \\
\hline & $(.08824)$ & $(.1123)$ & $(.1336)$ & $(.09483)$ & $(.124)$ & $(.3428)$ \\
\hline \multirow[t]{2}{*}{ L1.GDPcap } & $1.995^{* * *}$ & .5687 & .1429 & $1.1439^{*}$ & .4019 & $-3.545^{* *}$ \\
\hline & $(.6812)$ & $(.7273)$ & $(1.036)$ & $(.8411)$ & $(1.23)$ & $(1.681)$ \\
\hline \multirow[t]{2}{*}{ L1.Popdensity } & .1154 & -.1715 & -.1886 & .02255 & .1603 & $-.4697^{*}$ \\
\hline & $(.09082)$ & $(.1152)$ & $(.1714)$ & $(.09134)$ & $(.1756)$ & $(.2583)$ \\
\hline Pre-sample history & Yes & Yes & Yes & Yes & Yes & Yes \\
\hline Pre-sample dummy & Yes & Yes & Yes & Yes & Yes & Yes \\
\hline Firm FE & Yes & Yes & Yes & Yes & Yes & Yes \\
\hline Year dummy & Yes & Yes & Yes & Yes & Yes & Yes \\
\hline Country dummy & No & No & No & Yes & Yes & Yes \\
\hline Year x Country dummy & No & No & No & No & No & No \\
\hline Number of observations & 50687 & 12880 & 11956 & 40951 & 10469 & 10325 \\
\hline
\end{tabular}

Significance levels: $\quad{ }^{* * *}: 1 \% \quad{ }^{* *}: 5 \% \quad{ }^{*}: 10 \%$

Note: The top five countries are the US, Japan, Germany, France, and Great Britain. 


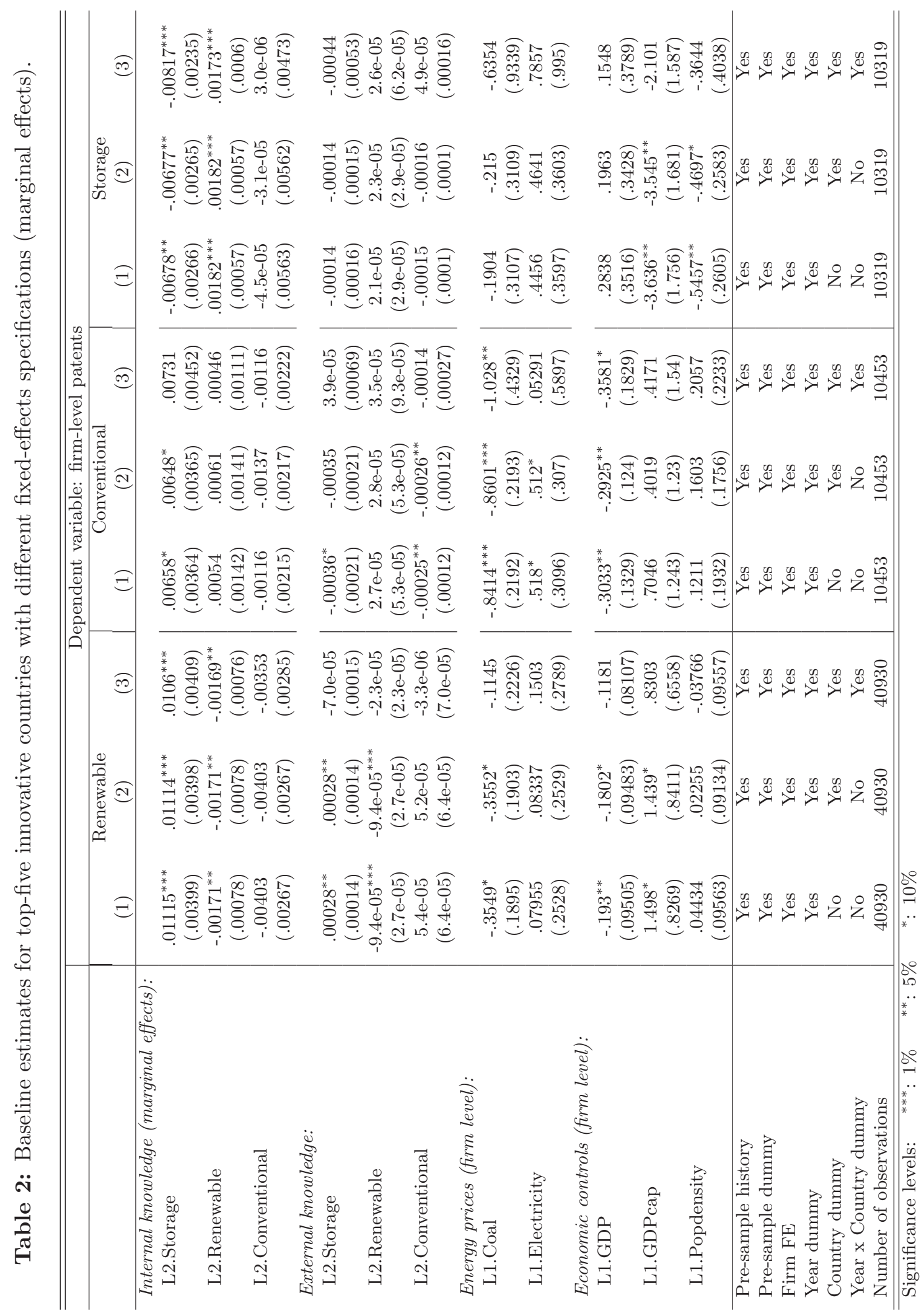


Table 3: Baseline model with intermittent renewable, peak-power fossil fuel, and storage technologies.

\begin{tabular}{|c|c|c|c|c|c|c|}
\hline & \multicolumn{6}{|c|}{ Dependent variable: firm-level patents } \\
\hline & \multicolumn{3}{|c|}{ All countries } & \multicolumn{3}{|c|}{ Top five countries } \\
\hline & Renewable & Conventional & Storage & Renewable & Conventional & Storage \\
\hline \multicolumn{7}{|c|}{ Internal knowledge (marginal effects): } \\
\hline L2.Storage & $\begin{array}{c}.01159^{* * *} \\
(.00372)\end{array}$ & $\begin{array}{c}.00293 \\
(.00346)\end{array}$ & $\begin{array}{c}-.00755^{* * *} \\
(.00256)\end{array}$ & $\begin{array}{c}.01144^{* * *} \\
(.00397)\end{array}$ & $\begin{array}{c}.0011 \\
(.00378)\end{array}$ & $\begin{array}{c}-.00673^{* * *} \\
(.00229)\end{array}$ \\
\hline L2.Renewable & $\begin{array}{c}-.00223^{* *} \\
(.00094)\end{array}$ & $\begin{array}{l}-.00089 \\
(.00225)\end{array}$ & $\begin{array}{c}.00188^{* * *} \\
(.00062)\end{array}$ & $\begin{array}{c}-.00207^{* *} \\
(.00097)\end{array}$ & $\begin{array}{l}-.00014 \\
(.00248)\end{array}$ & $\begin{array}{l}.0018^{* * *} \\
(.00066)\end{array}$ \\
\hline L2.Conventional & $\begin{array}{l}-.00275 \\
(.00894)\end{array}$ & $\begin{array}{c}-.02432^{* * *} \\
(.00581)\end{array}$ & $\begin{array}{c}.011 \\
(.00938)\end{array}$ & $\begin{array}{l}-.00385 \\
(.00925)\end{array}$ & $\begin{array}{c}-.02468^{* * *} \\
(.00722)\end{array}$ & $\begin{array}{c}.01174 \\
(.00878)\end{array}$ \\
\hline \multicolumn{7}{|l|}{ External knowledge: } \\
\hline L2.Storage & $\begin{array}{l}.00041^{* *} \\
(.00017)\end{array}$ & $\begin{array}{c}6.9 \mathrm{e}-05 \\
(.00039)\end{array}$ & $\begin{array}{c}.00016 \\
(.00019)\end{array}$ & $\begin{array}{c}.00022 \\
(.00018)\end{array}$ & $\begin{array}{c}-.0003 \\
(.00052)\end{array}$ & $\begin{array}{c}-.00014 \\
(.0002)\end{array}$ \\
\hline L2.Renewable & $\begin{array}{c}-.00013^{* * *} \\
(4.0 \mathrm{e}-05)\end{array}$ & $\begin{array}{c}8.4 \mathrm{e}-06 \\
(.00012)\end{array}$ & $\begin{array}{l}-3.9 \mathrm{e}-05 \\
(6.6 \mathrm{e}-05)\end{array}$ & $\begin{array}{l}-7.1 \mathrm{e}-05 \\
(4.4 \mathrm{e}-05)\end{array}$ & $\begin{array}{c}.00012 \\
(.00014)\end{array}$ & $\begin{array}{c}3.5 \mathrm{e}-05 \\
(7.6 \mathrm{e}-05)\end{array}$ \\
\hline L2.Conventional & $\begin{array}{c}.00041 \\
(.00108)\end{array}$ & $\begin{array}{l}-.00373 \\
(.00246)\end{array}$ & $\begin{array}{c}.00051 \\
(.00128)\end{array}$ & $\begin{array}{l}-.00048 \\
(.00125)\end{array}$ & $\begin{array}{c}-.00625^{* *} \\
(.00288)\end{array}$ & $\begin{array}{c}.0005 \\
(.00156)\end{array}$ \\
\hline \multicolumn{7}{|l|}{ Energy prices (firm level): } \\
\hline L1.Coal & $\begin{array}{c}-.3783^{* *} \\
(.1875)\end{array}$ & $\begin{array}{c}-.07492 \\
(.3891)\end{array}$ & $\begin{array}{l}-.1219 \\
(.2395)\end{array}$ & $\begin{array}{c}-.5268^{* *} \\
(.2501)\end{array}$ & $\begin{array}{c}-.07892 \\
(.6073)\end{array}$ & $\begin{array}{l}-.2223 \\
(.3236)\end{array}$ \\
\hline L1.Electricity & $\begin{array}{l}.03918 \\
(.2699)\end{array}$ & $\begin{array}{l}-.3979 \\
(.4609)\end{array}$ & $\begin{array}{c}.3167 \\
(.2545)\end{array}$ & $\begin{array}{c}.1726 \\
(.3133)\end{array}$ & $\begin{array}{l}-.1967 \\
(.7716)\end{array}$ & $\begin{array}{l}.5098 \\
(.3671)\end{array}$ \\
\hline \multicolumn{7}{|c|}{ Economic controls (firm level): } \\
\hline L1.GDP & $\begin{array}{l}-.1243 \\
(.1431)\end{array}$ & $\begin{array}{l}-.2135 \\
(.2785)\end{array}$ & $\begin{array}{c}.02049 \\
(.07218)\end{array}$ & $\begin{array}{l}-.2082^{*} \\
(.1076)\end{array}$ & $\begin{array}{c}.3865 \\
(.5081)\end{array}$ & $\begin{array}{c}-.00243 \\
(.1023)\end{array}$ \\
\hline L1.GDPcap & $\begin{array}{c}2.512^{* * *} \\
(.8046)\end{array}$ & $\begin{array}{l}-.4988 \\
(1.162)\end{array}$ & $\begin{array}{c}.1893 \\
(1.002)\end{array}$ & $\begin{array}{c}1.008 \\
(.8489)\end{array}$ & $\begin{array}{l}-4.437 \\
(4.137)\end{array}$ & $\begin{array}{c}-2.076^{* *} \\
(.817)\end{array}$ \\
\hline L1.Popdensity & $\begin{array}{c}.1529 \\
(.1073)\end{array}$ & $\begin{array}{c}.3002 \\
(.1961)\end{array}$ & $\begin{array}{l}-.178 \\
(.1801)\end{array}$ & $\begin{array}{l}-.1101 \\
(.1073)\end{array}$ & $\begin{array}{l}.3235 \\
(.524)\end{array}$ & $\begin{array}{c}-.4105^{*} \\
(.222)\end{array}$ \\
\hline Pre-sample history & Yes & Yes & Yes & Yes & Yes & Yes \\
\hline Pre-sample dummy & Yes & Yes & Yes & Yes & Yes & Yes \\
\hline Firm FE & Yes & Yes & Yes & Yes & Yes & Yes \\
\hline Year dummy & Yes & Yes & Yes & Yes & Yes & Yes \\
\hline Country dummy & No & No & No & Yes & Yes & Yes \\
\hline Year x Country dummy & No & No & No & No & No & No \\
\hline Number of observations & 33583 & 4107 & 11569 & 27910 & 3356 & 9956 \\
\hline
\end{tabular}

Significance levels: $\quad{ }^{* * *}: 1 \%{ }^{* *}: 5 \% \quad{ }^{*}: 10 \% \quad{ }^{\dagger}: 15 \%$

Note: The top five countries are the US, Japan, Germany, France, and Great Britain.

\subsection{Caveats}

To complete our empirical analysis, we discuss potential caveats. Specifically, we investigate the choice of estimator, the selection of electricity patents, alternative energy prices, innovation policies, 
adequate lag structures, sample selection (firm size and countries), quality of patents, and storage capacity. We start by considering the choice of estimator.

We use FE Poisson to estimate our baseline specification. However, when patent data exhibit over-dispersion, with a variance larger than the mean, a negative binomial could be the correct estimator. While our complete balanced panel data may exhibit over-dispersion, this is less of an issue with the unbalanced panel data set of active firms we used in our estimations. Note also that even with over-dispersion, the negative binomial is not necessarily an appropriate estimator for our main specification due to the large number of fixed effects in our model, which the negative binomial handles poorly. To estimate our baseline model with a negative binomial estimator, we therefore use data only on the most innovative firms located in the five most innovate countries, which considerably reduce the number of dummies that control for fixed effects. Table B.1 presents the estimation results. As expected because of the aforementioned issue with the negative binomial, we obtain tiny standard errors, which make most estimated parameters seem significant. While yielding low standard errors, these results nonetheless suggest that our main results are robust to this specification.

Next we consider alternative definitions of renewable and conventional technologies. Table B.2 only includes intermittent renewable energy patents and the estimated parameters show that our main results are robust to this specification. Specifically, we find that past innovation in storage increases the probability to apply for a renewable patent by $1.11 \%$ and an efficiency-improving fossil fuel patent by $0.52 \%$. The impact of storage on fossil fuel patents is less sharp than in our baseline estimates as this point estimate now only is significant at the $13 \%$ level. ${ }^{40}$

In addition, our baseline specification in Tables 1 and 2 limits conventional technologies to efficiency-improving fossil-fuel technologies whereas Table 3 concentrates on peak-power fossil-fuel generation technologies. In Table B.4 in the appendix, we include both efficiency-improving and general fossil fuel technologies. There is almost no impact on the estimated coefficients for renewable and storage technologies, however, the standard errors of the estimated coefficients for conventional technologies are higher and the coefficients are no longer significant at conventional levels. We therefore conclude that our main results are robust to a broader definition of conventional technologies but that storage is most beneficial for efficiency-improving technologies. Specifically, we find that an additional storage patent two years ago increases the probability of applying for a patent in efficiency-improving technologies today by $0.66 \%$ (Table 1), peak-power conventional technologies by $0.29 \%$ (Table 3 ) and all conventional technologies by $0.34 \%$ (Table B.4).

Next, we consider alternative energy prices. Our baseline results show that an increase in the coal price reduces innovation in both generation and storage. However, our robustness analysis shows that other fossil-fuel prices, natural gas and oil, do not have the same impact on innovation

\footnotetext{
${ }^{40} \mathrm{~A}$ related issue is the classification of renewable technologies. Instead of using WIPO's complete list of technologies as in our baseline estimations, we use the classification codes employed by Johnstone et al. (2010) and show that our main results are robust also to this technology definition (Table B.3).
} 
(see Tables B.5 and B.6). This is perhaps not surprising as during out sampling period coal is used primarily in base-load production, whereas natural gas is the dominant fuel in peak-load production, and oil often is considered to be a mid-load fuel. ${ }^{41}$ However, regardless of which fuel we use to proxy the fuel price, our main results regarding the role of storage on innovation are consistent. ${ }^{42}$

A related issue is the potential endogeneity of energy prices in our estimations. Our baseline specification includes electricity input and output prices, which are both affected by innovation in the industry. To investigate this potential endogeneity issue further, we exclude the electricity price from our specification. Columns (4) of Tables B.5 and B.6 in the appendix show that our results are robust. Another way to deal with the potential endogeneity issue is by lagging potentially endogenous variables, which we turn to below.

In addition to energy-tax policies, many countries implement direct and indirect policies to promote the development and deployment of renewable technologies. These policies include research subsidies to promote the invention of new technologies and feed-in tariffs to promote the deployment of renewable technologies. Thus far, we have controlled for country-specific policies with country and country-by-year fixed effects. Here, we seek to quantify the effect of such policies on the development of storage technologies. Specifically, we estimate our baseline specification to include research subsidies in storage, renewable, general fossil fuel and efficiency-improving fossil fuel subsidies. These data are available for 26 of the 79 countries in our sample. Since data on feed-in tariffs and other policies are unavailable, we control for these with fixed effects as in our baseline model. Table B.7 shows that increasing R\&D subsidies in efficiency-improving fossil-fuels has a statistically significant positive effect on the development of storage technologies in the 26 country sample. Specifically, we find that a $10 \%$ increase in efficiency-improving research subsidies increases the probability to apply for a storage patent by $1.7 \%$. Other effects are consistent with the baseline results, and we conclude that our main estimation results are robust to variation in country-specific policies.

Next, we consider two issues related to the timing of innovation. First, we consider different lag structures for the knowledge stocks and second, we address the truncation bias due to the lag between patent application and patent granted. We present an extensive analysis and estimation results in section B.v of the appendix. As Tables B.8-B.12 show, our main results are robust to issues related to the timing of innovation. In Appendix B.vi we consider issues related to sample selection, such as alternative firm sizes, different countries and different definitions of spillovers.

\footnotetext{
${ }^{41}$ We find that the natural gas price does not have a statistically significant impact on innovation in the electricity sector, but the coefficients indicate a positive effect on innovation in efficiency-improving conventional technologies and a negative effect on innovation in renewables and storage technologies. The estimated coefficients for how the oil price affects innovation are generally insignificant, but at the $5 \%$ statistical significance level, we find that a higher oil price promotes innovation in renewable technologies (full sample).

${ }^{42}$ See Lazkano and Pham (2016) for an in depth analysis of the impact of different energy prices in innovation in the electricity sector. They evaluate the impact of different fossil fuel prices in electricity generation by disaggregating electricity generating technologies into coal, natural gas, oil, hydro, and renewables.
} 
The estimation results for these subsamples, as shown in Tables B.13-B.17, are consistent with our baseline results.

Another potential issue relates to the vast heterogeneity in the quality of patents. We use data on TRIADIC patents, which are patents applied for in the three main patent offices: the US, the Japanese, and the European patent offices. Since protecting ideas in all main patent offices takes effort, we take this as a sign that inventors think highly of the value of their patents. This, however, does not directly control for quality differences among TRIADIC patents. We address this by constructing citation-adjusted knowledge stocks following Hall et al. (2005). The description of the data are presented in A.v. We estimate our baseline model using citation-adjusted knowledge stocks in table B.18. These results show that our main results are robust to using citations to control for the quality of patents. ${ }^{43}$

Finally, we estimate the baseline model controlling for installed storage capacity. We consider three alternatives. First, Tables B.19 and B.20 report the results when controlling for pumped hydro and total storage capacity, respectively. The storage capacity variables are not significant in any of the estimations, nor do the inclusion of these additional controls affect our main results. The second specification considers local and regional pumped hydro storage capacity instead of internal and external storage knowledge stocks. ${ }^{44}$ Table B.21 shows that all storage capacity coefficients are insignificant, while the main results for storage's effect on innovation in generation are qualitatively robust. These results indicate that the amount of storage capacity installed during our sampling period is too limited to significantly affect innovation. In addition, pumped hydro storage capacity is geographically concentrated and offers limited expansion opportunities, whereas most innovation in storage relates to other electricity storage technologies. The impact of installed storage capacity might change in the coming decades as new storage technologies contribute to further increasing the storage capacity in global electricity markets. In the third specification, we estimate the baseline model controlling for the share of electricity production from hydroelectric sources. Specifically, we include the share of electricity production from hydro as an explanatory variable in our baseline model and report our results in Table B.23. The hydropower variable is not significant and the inclusion of this additional explanatory variable does not affect our main results. We do not find this surprising as our baseline estimates control for country fixed effects, and the shares of hydroelectric power do not change much over time.

Overall, these exercises show that our main results are robust to a number of different model specifications and assumptions.

\footnotetext{
${ }^{43}$ Note that we only have citation data for $71.02 \%$ of our observations, and therefore we only use citation adjusted weights in our robustness analysis.

${ }^{44}$ In appendix B.viii, we further explore the link between innovation and installed storage capacity.
} 


\section{Conclusion}

Overcoming the intermittency problem of renewable energy is critical for their expansion and to curb global carbon emissions. Both policy makers and scientists point to electricity storage as the remedy for this problem. In this study, we investigate the incentives for developing storage technologies and their role in steering innovation towards renewable energy. Whereas past economic research on storage focuses on the benefits for renewable technologies, our paper analyzes the role of electricity storage for the entire electricity sector. Building on a directed technological change framework, we think of electricity storage as a process that improves the elasticity of substitution between renewable and conventional electricity production. Using global firm-level patent data from 1963 to 2011, we present empirical evidence that storage technologies positively affect innovation in both renewable and efficiency-improving conventional electricity generation. Specifically, an additional storage patent at the firm level leads to a $1.11 \%$ higher probability to apply for a renewable energy patent and a $0.66 \%$ higher probability to apply for an efficiency-improving conventional patent. Furthermore, our results show that the effect of storage innovation on conventional technologies varies with the type of technology. This implies that the availability of electricity storage technologies can change the conventional power generation mix.

Our study contributes to the literature on green innovation by providing the first empirical evidence on the role of electricity storage in the electricity sector. We also contribute to the literature on energy prices and innovation by offering new insights into the relationship between fossil fuel prices and innovation in electricity generation.

Our results provide several policy implications. First, our results add nuance to the policy debate on curbing carbon emissions. We find that the development of storage solutions promote innovation not only in renewable technologies but also in efficiency-improving conventional technologies. In addition, we find evidence for a positive feedback effect between innovation in renewables and in storage, whereas we find no such relationship between innovation in conventional generation and storage. Therefore, whether storage will curb carbon emissions from the electricity sector depends on two main factors: the competitiveness of renewable energy against conventional electricity generation, and the conventional generation mix as storage increases the efficiency of fossil-fuel technologies and reduces the role of ramping costs. This implies that policy makers cannot rely on the mere existence of electricity storage solutions to boost the use of renewable energy or to reduce carbon emissions. More energy-efficient, and thus cleaner, conventional generation technologies and better electricity storage solutions will increase the potential for reducing carbon emissions from the electricity sector. However, policy measures are needed to ensure that this potential is utilized, by increasing the share of renewable energy and preventing a transition toward dirtier base-load fuels such as coal.

Second, our results bring new insights into the debate on carbon pricing in the electricity sector. Contrary to what we initially expected, our empirical results show that a higher coal 
price not only discourages innovation in conventional technologies but also reduces innovation in renewable technologies. A plausible explanation for the negative impact on renewables is that without electricity storage, intermittent renewable electricity relies on conventional electricity as a buffer to ensure grid balance. This suggests that until more efficient storage solutions are available, conventional electricity is a complement for intermittent renewable electricity. In the light of this, the negative impact of the fuel price on innovation in renewables is less surprising. Thus, until better storage solutions are available, policy makers should consider accompanying policy measures when using the fuel price as an instrument to steer innovation toward renewable technologies.

Finally, although our results may be somewhat sobering in terms of the role of storage in reducing carbon emissions, our empirical results offer more encouraging insights for the flexibility of the electricity sector. We find that better storage solutions can foster energy efficiency in both conventional and renewable electricity generation. This enables electricity system operators to combine renewable and conventional electricity more efficiently as they face rising pressure to meet an increasing and volatile electricity demand, in addition to stringent environmental regulations. Thus, electricity storage can enhance energy security and reduce blackouts by increasing the flexibility of electricity markets.

To conclude, better storage technologies can solve the main drawback of renewable electricity, the intermittency problem. In addition, our study shows that the development of better electricity storage solutions is beneficial beyond the arena of renewable technologies, as it improves the energy efficiency of the entire electricity sector. Finally, electricity storage has the potential to reduce emissions from the electricity sector, but to fully realize this potential, policy measures must be taken. 


\section{References}

Acemoglu, D., P. Aghion, L. Bursztyn, and D. Hemous (2012). The environment and directed technical change. American Economic Review 102(1), 131-166.

Acemoglu, D., U. Akcigit, N. Bloom, and W. R. Kerr (2013, April). Innovation, reallocation and growth. Working Paper 18993, National Bureau of Economic Research.

Acemoglu, D., U. Akcigit, D. Hanley, and W. Kerr (2016). Transition to clean technology. Journal of Political Economy 124(1), 52-104.

Aghion, P., A. Dechezleprêtre, D. Hemous, R. Martin, and J. Van Reenen (2016). Carbon taxes, path dependency and directed technical change: Evidence from the auto industry. Journal of Political Economy 124(1), 1-51.

Blundell, R., R. Griffith, and J. Van Reenen (1995). Dynamic count data models of technological innovation. The Economic Journal, 333-344.

Blundell, R., R. Griffith, and J. Van Reenen (1999). Market share, market value and innovation in a panel of british manufacturing firms. The Review of Economic Studies 66 (3), 529-554.

Blundell, R., R. Griffith, and F. Windmeijer (2002). Individual effects and dynamics in count data models. Journal of Econometrics 108(1), 113-131.

Bovenberg, A. and S. Smulders (1995). Environmental quality and pollution-augmenting technological change in a two-sector endogenous growth model. Journal of Public Economics 57(3), 369-391.

Bovenberg, A. and S. Smulders (1996). Transitional impacts of environmental policy in an endogenous growth model. International Economic Review 37(4), 861-893.

Buonanno, P., C. Carraro, and M. Galeotti (2003). Endogenous induced technical change and the costs of Kyoto. Resource and Energy economics 25(1), 11-34.

Calel, R. and A. Dechezleprêtre (2012). Environmental policy and directed technological change: evidence from the European carbon market. Review of Economics and Statistics (0).

Cameron, A. C. and P. K. Trivedi (2013). Regression analysis of count data, Volume 53. Cambridge university press.

Carlino, G. A., S. Chatterjee, and R. M. Hunt (2007). Urban density and the rate of invention. Journal of Urban Economics 61(3), 389-419. 
Dechezleprêtre, A. and M. Glachant (2014). Does foreign environmental policy influence domestic innovation? Evidence from the wind industry. Environmental and Resource Economics 58(3), 391-413.

Dernis, H. and M. Khan (2004). Triadic patent families methodology. Technical report, OECD Publishing.

Feenstra, R. C., R. Inklaar, and M. P. Timmer (2013). The next generation of the Penn World Table.

Gans, J. S. (2012). Innovation and climate change policy. American Economic Journal: Economic Policy 4 (4), 125-145.

Gerlagh, R. and B. van der Zwaan (2004). A sensitivity analysis of timing and costs of greenhouse gas emission reductions. Climatic Change 65(1-2), 39-71.

Goulder, L. H. and S. H. Schneider (1999). Induced technological change and the attractiveness of CO2 abatement policies. Resource and energy economics 21(3), 211-253.

Hall, B. H., A. Jaffe, and M. Trajtenberg (2005). Market value and patent citations. RAND Journal of economics, 16-38.

Hassler, J., P. Krusell, and C. Olovsson (2012). Energy-saving technical change. Technical report, National Bureau of Economic Research.

Hausman, J., B. H. Hall, and Z. Griliches (1984, July). Econometric models for count data with an application to the patents-R\&D relationship. Econometrica 52(4), 909-38.

IEA (2014). Energy prices in US dollars. http://www.oecd-ilibrary.org/energy/ data/end-use-prices/energy-prices-in-us-dollars_data-00442-en. DOI: http://dx.doi.org/10.1787/data-00442-en.

IEA (2015). IEA electricity information. Technical report, IEA Statistics.

Johnstone, N., I. Haščič, and D. Popp (2010). Renewable energy policies and technological innovation: Evidence based on patent counts. Environmental and Resource Economics 45(1), $133-155$

Joskoaw, P. L. (2011). Comparing the costs of intermittent and dispatchable electricity generating technologies. The American Economic Review 101 (3), 238-241.

King, G. (1989). A seemingly unrelated poisson regression model. Sociological Methods $\&$ Research $17(3), 235-255$. 
Lancaster, T. (2002). Orthogonal parameters and panel data. The Review of Economic Studies $69(3), 647-666$.

Lanzi, E., E. Verdolini, and I. Haščič (2011). Efficiency-improving fossil fuel technologies for electricity generation: Data selection and trends. Energy Policy 39(11), 7000-7014.

Lazkano, I., L. Nøstbakken, and M. Pelli (2016). From fossil fuels to renewables: The role of electricity storage. Working Paper No. 5969, CESifo.

Lazkano, I. and L. Pham (2016). Do fossil fuel taxes promote innovation in renewable electricity generation? Working Paper SAM: 16/2016, NHH.

Martinez, C. (2010). Insight into different types of patent families. Technical report, OECD Publishing.

Noailly, J. and R. Smeets (2015). Directing technical change from fossil-fuel to renewable energy innovation: An application using firm-level patent data. Journal of Environmental Economics and Management 72, 15-37.

Papageorgiou, C., M. Saam, and P. Schulte (2016). Substitution between clean and dirty energy inputs - a macroeconomic perspective. Review of Economics and Statistics, Forthcoming.

Popp, D. (2002). Induced innovation and energy prices. American Economic Review 92(1), 160180.

Popp, D. (2004). ENTICE: Endogenous technological change in the DICE model of global warming. Journal of Environmental Economics and Management 48(1), 742-768.

Popp, D. (2005). Lessons from patents: using patents to measure technological change in environmental models. Ecological Economics 54(2), 209-226.

Popp, D. (2006a). ENTICE-BR: The effects of backstop technology R\&D on climate policy models. Energy Economics 28(2), 188-222.

Popp, D. (2006b). Innovation in climate policy models: Implementing lessons from the economics of R\&D. Energy Economics 28(5), 596-609.

Thompson, S. B. (2011). Simple formulas for standard errors that cluster by both firm and time. Journal of Financial Economics 99(1), 1-10.

World Coal Association (2015). Available: http://www.worldcoal.org/coal/coal-market-pricing. [Last accessed: 15 April 2016]. 


\title{
Online Appendix
}

\section{A Data construction}

\section{A.i Data overview}

Table A.1: Variables and sources of data.

\begin{tabular}{|c|c|c|}
\hline Variable & Unit of measure & Source \\
\hline \multirow[t]{3}{*}{ Patents } & Number of patent applications & $\begin{array}{l}\text { OECD Triadic Patent Fami- } \\
\text { lies Database }\end{array}$ \\
\hline & Firm characteristics & OECD REGPAT Database \\
\hline & Firm characteristics & OECD HAN database \\
\hline Energy prices including taxes & $\begin{array}{l}\text { Constant } 2005 \text { national prices (in } \\
\text { millions of } 2005 \text { U.S. \$) }\end{array}$ & IEA Energy Prices \& Taxes \\
\hline Research subsidies & $\begin{array}{l}\text { Constant } 2005 \text { national prices (in } \\
\text { millions of } 2005 \text { U.S. } \$ \text { ) }\end{array}$ & $\begin{array}{lll}\text { IEA } & \text { Energy } & \text { Technology } \\
\text { RD\&D Statistics } & \end{array}$ \\
\hline Real GDP & $\begin{array}{l}\text { Constant } 2005 \text { national prices (in } \\
\text { millions of } 2005 \text { U.S. } \$ \text { ) }\end{array}$ & Penn World Table \\
\hline Population & Millions of people & Penn World Table \\
\hline Population density & $\begin{array}{l}\text { People per square } \mathrm{km} \text { of land } \\
\text { area }\end{array}$ & World Development Indicator \\
\hline Pumped hydro storage capacity & Kilowatts per hour & $\begin{array}{l}\text { DOE Global Energy Storage } \\
\text { Database }\end{array}$ \\
\hline
\end{tabular}

Table A.2: List of countries.

\begin{abstract}
Argentina, Australia, Austria, Bahamas, Barbados, Belgium, Belize, Bermuda, Brazil, Bulgaria, Cameroon, Canada, Cayman Islands, Chile, China, Colombia, Croatia, Cyprus, Czech Republic, Denmark, Dominica, Finland, France, Georgia, Germany, Greece, Hong Kong, Hungary, Iceland, India, Indonesia, Iran, Ireland, Israel, Italy, Japan, Kenya, Korea, Kuwait, Lithuania, Luxembourg, Malaysia, Mauritius, Mexico, Netherlands, New Zealand, Norway, Panama, Philippines, Poland, Portugal, Romania, Russian Federation, Saudi Arabia, Singapore, Slovakia, Slovenia, South Africa, Spain, Sri Lanka, Sweden, Switzerland, Taiwan, Thailand, Turkey, Ukraine, United Arab Emirates, Great Britain, United States of America.
\end{abstract}

\section{A.ii International patent classifications (IPC)}

Patent classification codes are developed by the World Intellectual Property Organization (WIPO) and provided by the IPO. The IPC codes listed in the IPC Green Inventory have been compiled by 
the IPC Committee of Experts in concordance with the United Nations Framework Convention on Climate Change (UNFCCC). For more information, see http://www . wipo.int/classifications/ ipc/en/est/.

Table A.3: Patent classes for efficiency-improving electricity generation technologies.

\begin{tabular}{|c|c|}
\hline IPC code & Description \\
\hline \multicolumn{2}{|l|}{ Coal gasification } \\
\hline C10J3 & $\begin{array}{l}\text { Production of combustible gases containing carbon monoxide from solid carbonaceous } \\
\text { fuels }\end{array}$ \\
\hline Improved burners & [Classes listed below excluding combinations with B60,B68,F24,F27] \\
\hline $\mathrm{F} 23 \mathrm{C} 1$ & $\begin{array}{l}\text { Combustion apparatus specially adapted for combustion of two or more kinds of fuel } \\
\text { simultaneously or alternately,at least one kind of fuel being fluent }\end{array}$ \\
\hline $\mathrm{F} 23 \mathrm{C} 5 / 24$ & $\begin{array}{l}\text { Combustion apparatus characterised by the arrangement or mounting of burners; dis- } \\
\text { position of burners to obtain a loop flame }\end{array}$ \\
\hline F23C6 & $\begin{array}{l}\text { Combustion apparatus characterised by the combination of two or more combustion } \\
\text { chambers }\end{array}$ \\
\hline F23B10 & $\begin{array}{l}\text { Combustion apparatus characterised by the combination of two or more combustion } \\
\text { chambers }\end{array}$ \\
\hline F23B30 & $\begin{array}{l}\text { Combustion apparatus with driven means for agitating the burning fuel; combustion } \\
\text { apparatus with driven means for advancing the burning fuel through the combustion } \\
\text { chamber }\end{array}$ \\
\hline F23B70 & $\begin{array}{l}\text { Combustion apparatus characterised by means for returning solid combustion residues } \\
\text { to the combustion chamber }\end{array}$ \\
\hline F23B80 & $\begin{array}{l}\text { Combustion apparatus characterised by means creating a distinct flow path for fluegases } \\
\text { or for non-combusted gases given off by the fuel }\end{array}$ \\
\hline F23D1 & Burners for combustion of pulverulent fuel \\
\hline F23D7 & Burners in which drops of liquid fuel impinge on a surface \\
\hline F23D17 & $\begin{array}{l}\text { Burners for combustion simultaneously or alternatively of gaseous or liquid or pulveru- } \\
\text { lent fuel }\end{array}$ \\
\hline \multicolumn{2}{|c|}{ Fluidised bed combustion } \\
\hline B01J8/20-22 & $\begin{array}{l}\text { Chemical or physical processes in general, conducted in the presence of fluids and solid } \\
\text { particles; apparatus for such processes; with liquid as a fluidising medium }\end{array}$ \\
\hline B01J8/24-30 & $\begin{array}{l}\text { Chemical or physical processes in general, conducted in the presence of fluids and solid } \\
\text { particles; apparatus for such processes; according to "fluidised-bed" technique }\end{array}$ \\
\hline F27B15 & $\begin{array}{l}\text { Fluidised bed furnaces; Other furnaces using or treating finely divided materials in } \\
\text { dispersion }\end{array}$ \\
\hline $\mathrm{F} 23 \mathrm{C} 10$ & Apparatus in which combustion takes place in afluidised bed of fuel or other particles \\
\hline \multicolumn{2}{|c|}{ Improved boilers for steam generation } \\
\hline F22B31 & $\begin{array}{l}\text { Modifications of boiler construction, or of tube systems, dependent on installation of } \\
\text { combustion apparatus; Arrangements or dispositions of combustion apparatus }\end{array}$ \\
\hline F22B33/14-16 & $\begin{array}{l}\text { Steam generation plants,e.g.comprising steam boilers of different types in mutual asso- } \\
\text { ciation; combinations of low-and high-pressure boilers }\end{array}$ \\
\hline \multicolumn{2}{|c|}{ Improved steam engines } \\
\hline F01K3 & $\begin{array}{l}\text { Plants characterised by the use of steam or heat accumulators, or intermediate steam } \\
\text { heaters, therein }\end{array}$ \\
\hline
\end{tabular}


Table A.3 - continued from previous page

\begin{tabular}{|c|c|}
\hline IPC code & Description \\
\hline F01K5 & $\begin{array}{l}\text { Plants characterised by use of means for storing steam in an alkali to increases team } \\
\text { pressure,e.g. of Honigmann or Koenemann type }\end{array}$ \\
\hline F01K23 & $\begin{array}{l}\text { Plants characterised by more than one engine delivering power external to the plant, } \\
\text { the engines being driven by different fluids }\end{array}$ \\
\hline \multicolumn{2}{|l|}{ Super-heaters } \\
\hline $\mathrm{F} 22 \mathrm{G}$ & Steam super heating characterised by heating method \\
\hline \multicolumn{2}{|c|}{ Improved gas turbines } \\
\hline F02C7/08-105 & $\begin{array}{l}\text { Features, component parts, details or accessories; heating air supply before combus- } \\
\text { tion,e.g. by exhaust gases }\end{array}$ \\
\hline $\mathrm{F} 02 \mathrm{C} 7 / 12-143$ & Features, component parts, details or accessories; cooling of plants \\
\hline $\mathrm{F} 02 \mathrm{C} 7 / 30$ & $\begin{array}{l}\text { Features, component parts, details or accessories; preventing corrosion in gas-swept } \\
\text { spaces }\end{array}$ \\
\hline \multicolumn{2}{|c|}{ Combined cycles } \\
\hline F01K23/02-10 & $\begin{array}{l}\text { Plants characterised by more than one engine delivering power external to the plant, } \\
\text { the engines being driven by different fluids; the engine cycles being thermally coupled }\end{array}$ \\
\hline F02C3/20-36 & $\begin{array}{l}\text { Gas turbine plants characterised by the use of combustion products as the working fluid; } \\
\text { using special fuel, oxidant or dilution fluid to generate the combustion products }\end{array}$ \\
\hline F02C6/10-12 & $\begin{array}{l}\text { Plural gas-turbine plants; combinations of gas-turbine plants with other apparatus; sup- } \\
\text { plying working fluid to a user,e.g. a chemical process, which returns working fluid to a } \\
\text { turbine of the plant }\end{array}$ \\
\hline \multicolumn{2}{|c|}{ Improved compressed-ignitionengines } \\
\hline \multicolumn{2}{|c|}{ [Classes listed below excluding combinations with B60,B68,F24,F27] } \\
\hline F02B1/12-14 & Engines characterised by fuel-air mixture compression; with compression ignition \\
\hline F02B3/06-10 & Engines characterised by fuel-air mixture compression; with compression ignition \\
\hline F02B7 & $\begin{array}{l}\text { Engines characterised by the fuel-air charge being ignited by compression ignition of an } \\
\text { additional fuel }\end{array}$ \\
\hline F02B11 & $\begin{array}{l}\text { Engines characterised by both fuel-air mixture compression and air compression, or } \\
\text { characterised by both positive ignition and compression ignition,e.g.indifferent cylinders }\end{array}$ \\
\hline F02B13/02-04 & $\begin{array}{l}\text { Engines characterised by the introduction of liquid fuel into cylinders by use of auxiliary } \\
\text { fluid; compression ignition engines using air or gas for blowing fuel into compressed air } \\
\text { in cylinder }\end{array}$ \\
\hline F02B49 & $\begin{array}{l}\text { Methods of operating air- compressing compression-ignition engines involving introduc- } \\
\text { tion of small quantities of fuel in the form of a fine mist into the air in the engine's } \\
\text { intake }\end{array}$ \\
\hline \multicolumn{2}{|l|}{ Co-generation } \\
\hline F01K17/06 & $\begin{array}{l}\text { Use of steam or condensate extracted or exhausted from steam engine plant; returning } \\
\text { energy of steam, in exchanged form,to process,e.g. use of exhaust steam for drying solid } \\
\text { fuel of plant }\end{array}$ \\
\hline F01K27 & Plants for converting heat or fluid energy into mechanical energy \\
\hline $\mathrm{F} 02 \mathrm{C} 6 / 18$ & $\begin{array}{l}\text { Plural gas-turbine plants; combinations of gas-turbine plants with other apparatus; using } \\
\text { the waste heat of gas-turbine plants outside the plants themselves, e.g. gas-turbine power } \\
\text { heat plants }\end{array}$ \\
\hline F02G5 & Profiting from waste heat of combustion engines \\
\hline
\end{tabular}


Table A.3 - continued from previous page

\begin{tabular}{ll}
\hline \hline IPC code & Description \\
\hline F25B27/02 & $\begin{array}{l}\text { Machines, plant, or systems, using particular sources of energy; using waste heat, e.g. } \\
\text { from internal-combustion engines }\end{array}$ \\
\hline Source: Lanzi et al. (2011). & \\
\hline
\end{tabular}

Table A.4: Patent classes for general fossil fuel technologies.

\begin{tabular}{ll}
\hline \hline IPC code & Description \\
\hline C10J & Production of fuel gases by carburetting air or other gases without pyrolysis \\
F01K & $\begin{array}{l}\text { Steam engine plants; steam accumulators; engine plants not otherwise provided for; engines } \\
\text { using special working fluids or cycles } \\
\text { Gas-turbine plants; air intakes for jet-propulsion plants; controlling fuel supply in air-breathing } \\
\text { F02C }\end{array}$ \\
& jet-propulsion plants \\
F02G & $\begin{array}{l}\text { Hot-gas or combustion-product positive-displacement engine; use of waste heat of combustion } \\
\text { engines otherwise provided for }\end{array}$ \\
F22 & Steam generation \\
F23 & Combustion apparatus; combustion processes \\
F27 & Furnaces; kilns; ovens; retorts \\
\hline
\end{tabular}

Source: Lanzi et al. (2011).

Table A.5: Patent classes for renewable electricity generation technologies.

\begin{tabular}{ll}
\hline \hline IPC code & Description \\
\hline H01M 4/86-4/98,8/00-8/24, & Fuel cells \\
12/00-12/08 & \\
H01M 4/86-4/98 & Electrodes \\
H01M 4/86-4/98 & Inert electrodes with catalytic activity \\
H01M 2/00-2/04,8/00-8/24 & Non-active parts \\
H01M 12/00-12/08 & Within hybrid cells \\
C10B 53/00, C10J & Pyrolysis or gasification of biomass \\
& Harnessing energy from manmade waste \\
C10L 5/00 & Agricultural waste \\
C10L 5/42, 5/44 & Fuel from animal waste and crop residues \\
F23G 7/00, 7/10 & Incinerators for field, garden or wood waste \\
C10J 3/02, 3/46, F23B & Gasification \\
90/00, F23G 5/027 & \\
B09B 3/00, F23G 7/00 & Chemical waste \\
C10L 5/48, F23G $5 / 00$, & Industrial waste \\
F23G 7/00 & \\
C21B 5/06 & Using top gas in blast furnaces to power pigiron production \\
D21C 11/00 & Pulp liquors \\
\hline
\end{tabular}


Table A.5 - continued from previous page

\begin{tabular}{|c|c|}
\hline IPC code & Description \\
\hline $\begin{array}{l}\mathrm{A} 62 \mathrm{D} \quad 3 / 02, \quad \mathrm{C} 02 \mathrm{~F} \quad 11 / 04 \\
11 / 14\end{array}$ & Anaerobic digestion of industrial waste \\
\hline F23G $7 / 00,7 / 10$ & Industrial wood waste \\
\hline B09B 3/00, F23G 5/00 & Hospital waste \\
\hline B09B & Landfill gas \\
\hline $\begin{array}{l}\text { B01D 53/02, 53/04, 53/047, } \\
53 / 14,53 / 22,53 / 24, \text { C10L } \\
5 / 46\end{array}$ & Separation of components \\
\hline F23G $5 / 00$ & $\begin{array}{l}\text { Municipal waste } \\
\text { Hydro energy }\end{array}$ \\
\hline E02B 9/00-9/06 & Water-power plants \\
\hline E02B 9/08 & Tide or wave power plants \\
\hline F03B, F03C & Machines or engines for liquids \\
\hline F03B 13/12-13/26 & Using wave or tide energy \\
\hline F03B 15/00-15/22 & Regulating, controlling or safety means of machines or engines \\
\hline В63H 19/02, 19/04 & Propulsion of marine vessels using energy derived from water movement \\
\hline F03G 7/05 & Ocean thermal energy conversion (OTEC) \\
\hline F03D & Wind energy \\
\hline H02K $7 / 18$ & Structural association of electric generator with mechanical driving motor \\
\hline $\begin{array}{l}\text { B63B 35/00, E04H } 12 / 00, \\
\text { F03D 11/04 }\end{array}$ & Structural aspects of wind turbines \\
\hline B60K 16/00 & Propulsion of vehicles using wind power \\
\hline B60L 8/00 & Electric propulsion of vehicles using wind power \\
\hline B63H 13/00 & $\begin{array}{l}\text { Propulsion of marine vessels by wind-powered motors } \\
\text { Solar energy }\end{array}$ \\
\hline $\begin{array}{l}\text { H01L } 27 / 142,31 / 0031 / 078 \\
\text { H01G 9/20, H02N } 6\end{array}$ & Devices adapted for the conversion of radiation energy into electrical energy \\
\hline H01L $27 / 30,51 / 42-51 / 48$ & Using organic materials as the active part \\
\hline $\begin{array}{l}\text { H01L } 25 / 00,25 / 03,25 / 16 \\
25 / 18,31 / 042\end{array}$ & Assemblies of a plurality of solar cells \\
\hline $\begin{array}{l}\text { C01B 33/02, C23C } 14 / 14 \\
16 / 24, \text { C30B } 29 / 06\end{array}$ & Silicon; single-crystal growth \\
\hline G05F $1 / 67$ & Regulating to the maximum power available from solar cells \\
\hline F21L 4/00, F21S 9/03 & Electric lighting devices with, or rechargeable with, solar cells \\
\hline H02J $7 / 35$ & Charging batteries \\
\hline H01G 9/20, H01M 14/00 & Dye-sensitised solar cells (DSSC) \\
\hline F24J $2 / 00-2 / 54$ & Use of solar heat \\
\hline F24D $17 / 00$ & For domestic hot water systems \\
\hline $\begin{array}{l}\text { F24D } 3 / 00, \quad 5 / 00, \quad 11 / 00 \\
19 / 00\end{array}$ & For space heating \\
\hline F24J $2 / 42$ & For swimming pools \\
\hline $\begin{array}{l}\text { F03D } 1 / 04, \quad 9 / 00, \quad 11 / 04 \\
\text { F03G } 6 / 00\end{array}$ & Solar updraft towers \\
\hline $\mathrm{C} 02 \mathrm{~F} 1 / 14$ & For treatment of water, waste water or sludge \\
\hline
\end{tabular}


Table A.5 - continued from previous page

\begin{tabular}{|c|c|}
\hline IPC code & Description \\
\hline F02C 1/05 & Gas turbine power plants using solar heat source \\
\hline H01L 31/058 & Hybrid solar thermal-PV systems \\
\hline B60K 16/00 & Propulsion of vehicles using solar power \\
\hline B60L 8/00 & Electric propulsion of vehicles using solar power \\
\hline F03G 6/00-6/06 & Producing mechanical power from solar energy \\
\hline E04D 13/00, 13/18 & Roof covering aspects of energy collecting devices \\
\hline F22B 1/00, F24J 1/00 & Steam generation using solar heat \\
\hline F25B $27 / 00$ & Refrigeration or heat pump systems using solar energy \\
\hline F26B 3/00, 3/28 & Use of solar energy for drying materials or objects \\
\hline F24J 2/06, G02B 7/183 & Solar concentrators \\
\hline F24J $2 / 04$ & Solar ponds \\
\hline & Geothermal energy \\
\hline $\begin{array}{l}\text { F01K, F24F 5/00, F24J 3/08, } \\
\text { H02N 10/00, F25B 30/06 }\end{array}$ & Use of geothermal heat \\
\hline F03G 4/00-4/06, 7/04 & Production of mechanical power from geothermal energy \\
\hline F24J 1/00, 3/00, 3/06 & Other production or use of heat, not derived from combustion, e.g. natural heat \\
\hline F24D 11/02 & Heat pumps in central heating systems using heat accumulated in storage masses \\
\hline F24D 15/04 & Heat pumps in other domestic- or space-heating systems \\
\hline F24D $17 / 02$ & Heat pumps in domestic hot-water supply systems \\
\hline $\mathrm{F} 24 \mathrm{H} 4 / 00$ & Air or water heaters using heat pumps \\
\hline F25B 30/00 & Heat pumps \\
\hline & Using waste heat \\
\hline F01K $27 / 00$ & To produce mechanical energy \\
\hline $\begin{array}{l}\text { F01K } 23 / 06-23 / 10, \quad \text { F01N } \\
5 / 00, \text { F02G 5/00-5/04, F25B }\end{array}$ & Of combustion engines \\
\hline $27 / 02$ & \\
\hline F01K 17/00;23/04 & steam engine plants \\
\hline F02C $6 / 18$ & Of gas-turbine plants \\
\hline F25B 27/02 & As source of energy for refrigeration plants \\
\hline $\mathrm{C} 02 \mathrm{~F} 1 / 16$ & For treatment of water, waste water or sewage \\
\hline D21F $5 / 20$ & Recovery of waste heat in paper production \\
\hline F22B 1/02 & For steam generation by exploitation of the heat content of hot heat carriers \\
\hline F23G 5/46 & Recuperation of heat energy from waste incineration \\
\hline $\mathrm{F} 24 \mathrm{~F} 12 / 00$ & Energy recovery in air conditioning \\
\hline F27D $17 / 00$ & Arrangements for using waste heat from furnaces, kilns, ovens or retorts \\
\hline F28D 17/00-20/00 & Regenerative heat-exchange apparatus \\
\hline C10J $3 / 86$ & Of gasification plants \\
\hline F03G 5/00-5/08 & Devices for producing mechanical power from muscle energy \\
\hline
\end{tabular}


Table A.6: Patent classes for electricity storage.

\begin{tabular}{ll}
\hline \hline IPC code & Description \\
\hline B60K 6/28 & Characterized by the electric energy storing means, e.g. batteries or capacitors \\
B60W 10/26 & For electrical energy, e.g. batteries or capacitors \\
H01M 10/44 & Methods for charging or discharging \\
H01M 10/46 & Accumulators structurally combined with charging apparatus \\
H01G 9/155 & Hybrid capacitors, i.e. capacitors having different positive and negative electrodes; Electric \\
& double-layer [EDL] capacitors; Processes for the manufacture thereof or parts thereof \\
H02J 3/28 & Arrangements for balancing the load in a network by storage of energy \\
H02J 7/00 & Circuit arrangements for charging or depolarizing batteries or for supplying loads from bat- \\
& teries \\
H02J 15/00 & Systems for storing electric energy \\
\hline Source: IPC Green Inventory, World Intellectul Property Organization.
\end{tabular}

Table A.7: Total number of patents in renewable technologies following different International Patent Classification (IPC) codes.

\begin{tabular}{lrr}
\hline \hline Technology & Literature & WIPO - Green Inventory \\
\hline Renewables & $\mathbf{8 4 , \mathbf { 1 3 5 }}$ & $\mathbf{1 7 8 , 8 4 1}$ \\
Geothermal & 1,156 & 2,123 \\
Hydro & 0 & 6,337 \\
Natural heat & 0 & 2,351 \\
Solar & 21,001 & 59,905 \\
Thermal & 0 & 43 \\
Waste & 0 & 27,361 \\
Waste heat & 0 & 2,326 \\
Wind & 5,778 & 5,770 \\
Fuel cells & 0 & 71,801 \\
Biomass & 0 & 808 \\
Muscle energy & 0 & 16 \\
Biomass and waste & 54,871 & 0 \\
\hline \hline
\end{tabular}

Notes: Literature refers to classification codes provided by Johnstone et al. (2010) while Table A.5 reports WIPO - Green Inventory codes.

The table reports the total number of patents in renewable technologies following two different classifications: WIPO's IPC Green Inventory and Johnstone et al. (2010) (labelled Literature). Our baseline estimates are based on the more extensive WIPO list of codes which totals 178,841 patents, in contrast to the list often used in the literature that contains 84,135 patents. The main difference in the patent count comes from fuel cells. Fuel cells provide electrical energy by activating a fuel to convert it into electricity. They generate about 0.6 Volts to 0.9 Volts DC per cell but they do not storage energy like batteries. Thus, they are an important source of renewable electricity generation. 


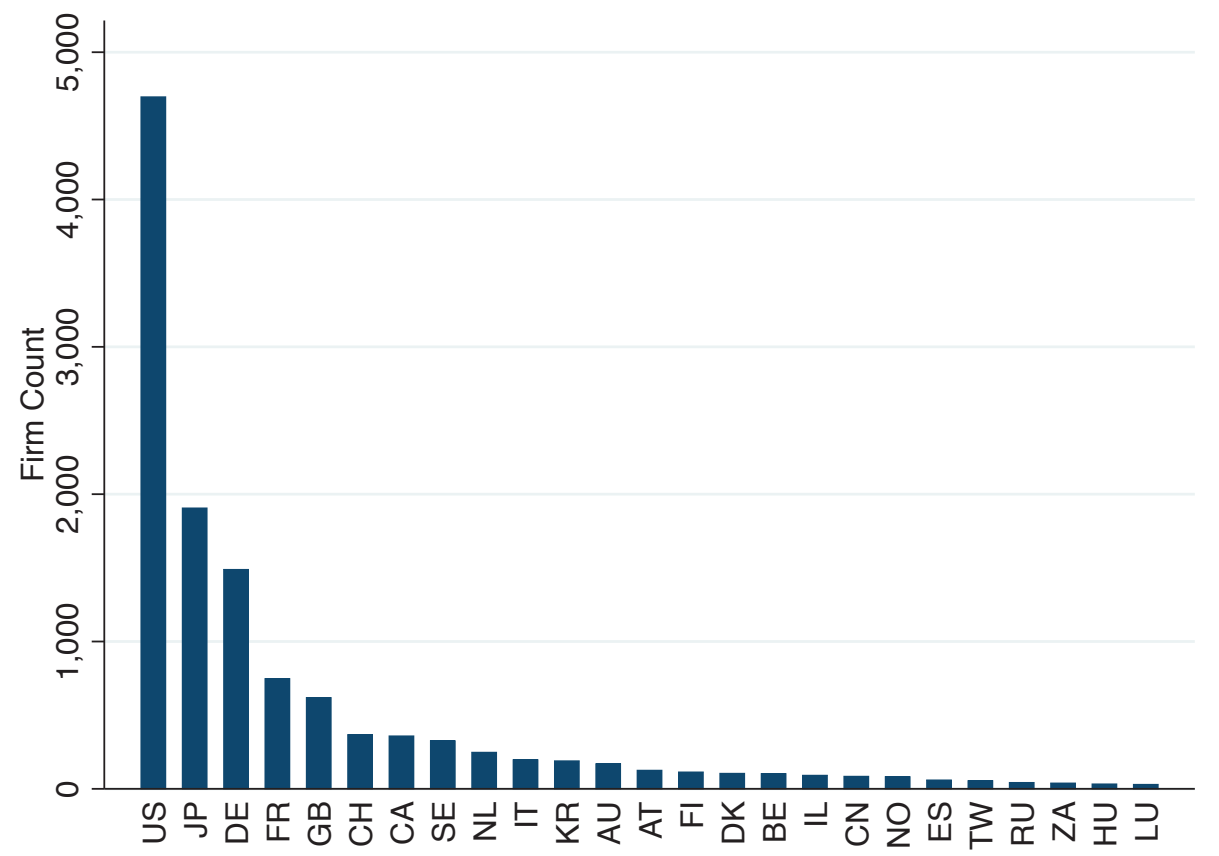

Figure A.1: Firm count by country for top-25 countries.

\section{A.iii Fuel and electricity prices}

The IEA data set contains both industry and household prices for the different commodities and, in some cases, prices for use in electricity generation. In addition, the data set reports prices on different types of coal and oil. As the different price series for each commodity are highly correlated, we select, for each country, the price series with the lowest number of missing values. Given this, we impose the following order of priority for uses: electricity generation, industry, and households. In addition, we impose the following order of priority for types of oil: high sulfur, low sulfur, and light oil; and the following order of priority for types of coal: steam coal and coking coal.

Fuel and electricity prices in different countries behave similarly over time, even though there are level differences. In addition, incomplete time series tend to have missing data at the beginning and/or end of the series. Given this, we fill the gaps in the energy price series by imposing the same annual growth over the missing range of the price series, as exhibited by a relevant reference price index. This addresses the issue of level differences between the reference price indices and the country-specific price series. In the case of non-OECD countries for which we do not have any energy price data, we simply impose the most relevant price index.

We choose the reference price for each country and energy type based on the characteristics of the different energy markets. As there are global markets for oil and coal, we use the respective global OECD price indices as reference prices. There is extensive international trade in oil, and international trade in coal currently accounts for about $25 \%$ of the total coal consumed (World 
Coal Association, 2015). Both oil and coal can travel large distances by ship in relatively little time. However, because transportation costs account for a significant share of the price of coal, international trade in this commodity generally occurs within two main regional markets: the Atlantic market, driven by importing countries in Western Europe, and the Pacific market, driven by imports to China, Japan, and Korea. Nonetheless, prices in these markets are closely related, justifying the use of a global price index.

Unlike oil and coal prices, our natural gas price data suggest some differences across regions. Being more difficult to move than coal or oil, natural gas has traditionally been more of a regional commodity, traded in three main markets: North America, Europe, and Asia. For this reason, we use regional prices as reference prices for natural gas. For Europe, we use the OECD Europe price index, whereas for Asia and the Middle East, we use the Japanese price series, as Japan is a key natural gas player in Asia. For the American continent, we use the Mexican natural gas price as the reference, as Mexico is geographically closer to the countries with missing data, and the Mexican price series is very similar to the US and Canadian prices. Finally, because we have no natural gas prices for Africa, we use the global OECD price index for gas in this region, which is our best measure of an average world price.

Finally, our data set reveals relatively large differences in electricity prices across countries and regions. Whereas fossil fuels used in electricity production can be shipped over large distances, it is harder to sell electricity in markets (grids) other than the market in which the electricity is produced. In addition, national and local regulations can have a big impact on electricity prices. This makes it more challenging to identify the appropriate reference price to fill in the missing data. For the American continent, where we lack information on countries in Central and South America, we use the Mexican electricity price as a reference. ${ }^{1}$ For Asia, the Middle East, and Africa, we use the global OECD price index. ${ }^{2}$

\section{A.iv Correcting for patent truncation bias}

We correct for the patent truncation bias due to the lag between patent application and patent granted following Hall et al. (2005). Specifically, we scale up the number of patent applications at the end of the data set using the grant-lag distribution. Figure A.2 illustrates the application-grant lag distribution in the USPTO using data from 1978 to 2006. This figure shows that within five years, $95 \%$ of patent applications are granted while $99 \%$ are granted in seven years.

\footnotetext{
${ }^{1}$ We have complete price series for the US, Canada, Mexico, and Chile. We choose the Mexican price because it is less volatile than the Chilean price and because, in terms of levels, it is located between the Chilean and the North American prices. For Europe, we use the OECD Europe price index, as the price differences among European countries are small.

${ }^{2}$ In Asia and the Middle East, electricity prices vary considerably across the relatively few countries for which we have data. We choose a reference price based on the global OECD price index, which is close to the average price over the countries for which we have data and does not exhibit extreme variation over time, which could have affected our results. For Africa, we have no electricity prices and resort to using the OECD (global) average as a best guess.
} 


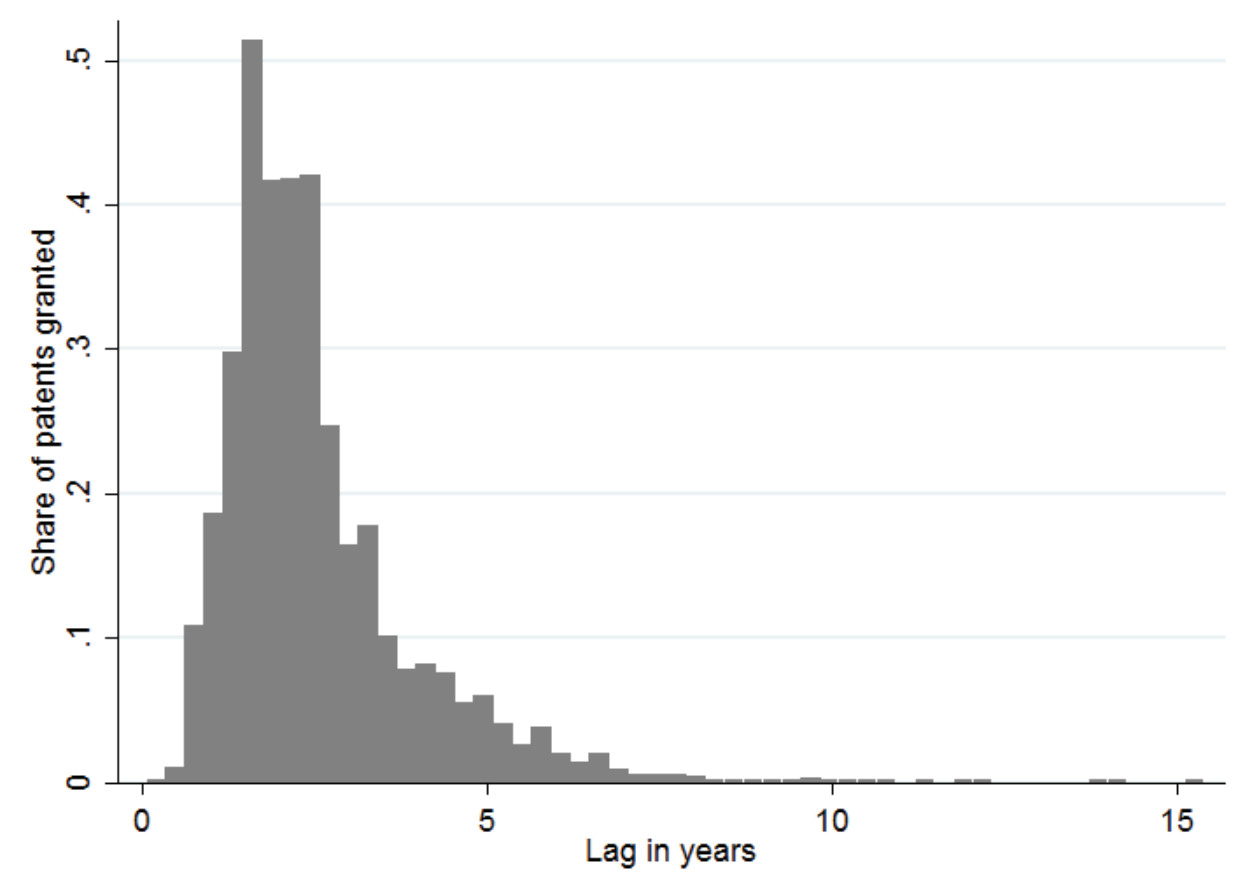

Figure A.2: Patent application and patent grant lag distribution in the USPTO from 1978 to 2006.

From the application-grant distribution in figure A.2, we calculate the share of patents granted after each lag. These weights are then used to scale up patent applications. Specifically, each year patent application is scaled up as:

$$
\hat{P}_{t}=\frac{P_{t}}{\sum_{s=0}^{2011-t} w_{s}} \quad 2004<t<2011
$$

where $\hat{P}_{t}$ is adjusted patent count, $P_{t}$ is the number of patent applications in year $t$ and $w_{s}$ are the weights presented in column 2 of table A.8. The last two columns of table A.8 show the scale we applied to patents from 2004 to 2011. For example, patent applications in 2009 are adjusted upward by 1.126 which means that $12.6 \%$ of patents applied for in 2009 are expected to be granted after 2010 . 
Table A.8: Truncation correction weights.

\begin{tabular}{ccc|cc}
\hline Lag & Weight & Cumulative weights & Year & Inverse weights \\
\hline 1 & .0459397 & .0459397 & 2012 & 21.76764 \\
2 & .3658777 & .4118175 & 2011 & 2.42826 \\
3 & .3562925 & .76811 & 2010 & 1.301897 \\
4 & .1198662 & .8879762 & 2009 & 1.126156 \\
5 & .0647385 & .9527147 & 2008 & 1.049632 \\
6 & .0292874 & .9820021 & 2007 & 1.018328 \\
7 & .0120648 & .9940669 & 2006 & 1.005969 \\
8 & .0037098 & .9977767 & 2005 & 1.002228 \\
9 & .0011149 & .9988915 & 2004 & 1.00111 \\
10 & .0007689 & .9996604 & 2003 & 1.00000 \\
\hline \hline
\end{tabular}

\section{A.v Quality of patents and citation data}

We draw data from the OECD's Citation Database (September 2016 edition). Specifically, we use citations received of EP and USPTO patents (forward patents). Unfortunately, there are data available for $71.02 \%$ of our observations. We have investigated whether there is a pattern in the patent applications for which we lack citation data. Using summary statistics we do not find evidence that specific technologies are affected by the lack of citation data. In addition, we do not find evidence that some major innovating countries contain less citation patents data than others.

We construct citation-adjusted knowledge stocks following Hall et al. (2005). First, we calculate total citation stocks per year and patent application using past citation stocks. Second, since there are differences in the percentage of applications with patents by year, we correct for this truncation in citations using the distribution of citation lag in years (figure A.3). Once we correct for the truncation problem, we calculate citation-adjusted knowledge stocks: Knowledge stock $_{t}=$ $\frac{\text { Citations }_{t}}{\text { Patents }_{t}}$. 


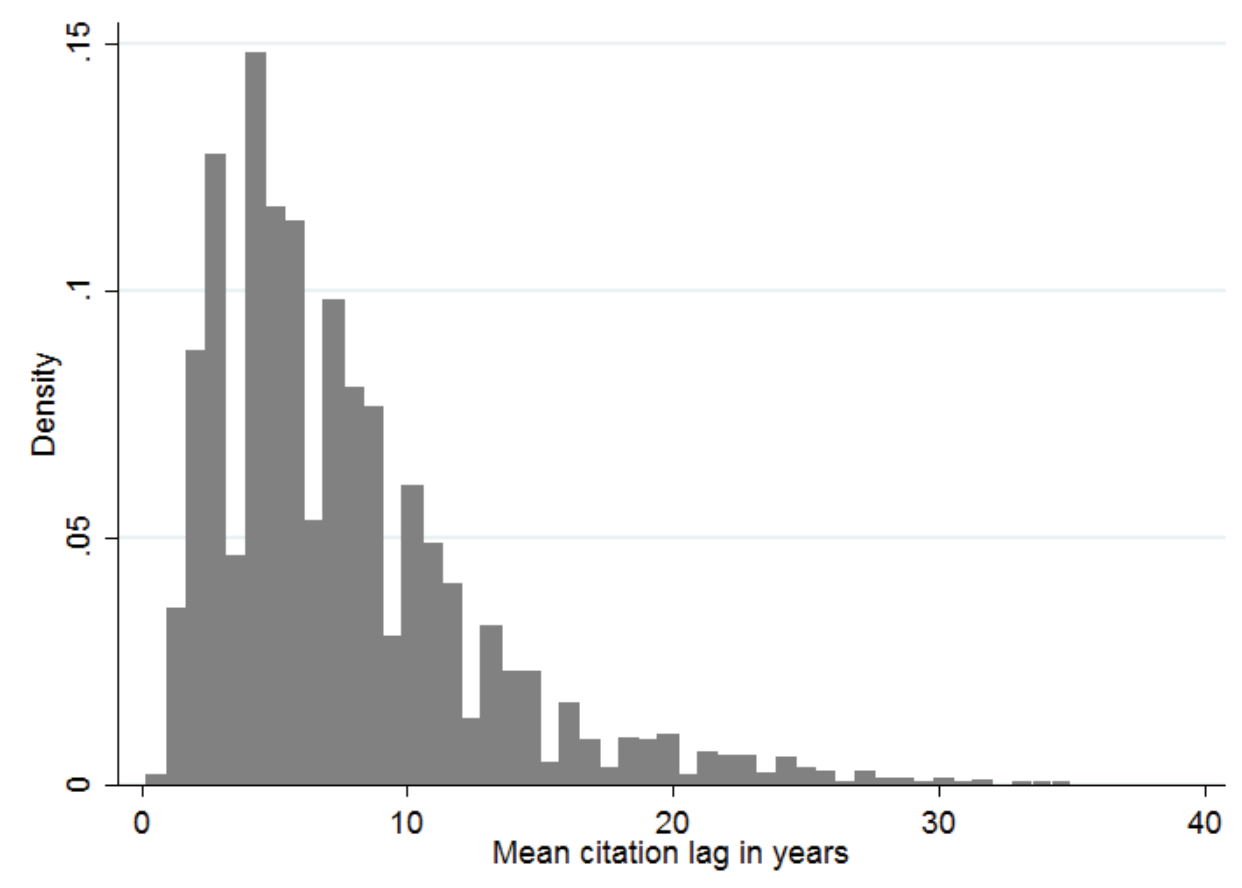

Figure A.3: Distribution of citation lag in years.

\section{B Robustness analysis}

As mentioned in section 5, we conduct an extensive robustness analysis to validate our results. First, we consider an alternative estimator in section B.i. In the baseline specification, conventional technologies include only efficiency-improving fossil-fuel technologies. Appendix B.ii, we estimate our main specification using data on both general and efficiency-improving fossil-fuel technologies as well as an alternative definition of renewable technologies using the definition of Johnstone et al. (2010) instead of WIPO. Third, Appendix B.iii considers alternative energy prices while appendix B.iv presents research subsidies. We also extend our analysis to different lag structures in B.v and analyze different sample selection issues and alternative definitions of regions in which knowledge spillovers occur in B.vi. Finally, we analyze storage capacity B.viii and other potential caveats in section B.ix. 


\section{B.i Alternative estimator}

Table B.1: Negative binomial estimation using top five innovating countries.

\begin{tabular}{|c|c|c|c|c|c|c|}
\hline & \multicolumn{6}{|c|}{ Dependent variable: firm-level patents } \\
\hline & \multicolumn{3}{|c|}{ All firms } & \multicolumn{3}{|c|}{ Top $10 \%$ innovators } \\
\hline & Renewable & Conventional & Storage & Renewable & Conventional & Storage \\
\hline \multicolumn{7}{|c|}{ Internal knowledge (marginal effects): } \\
\hline \multirow[t]{2}{*}{ L2.Storage } & $.00694^{* * *}$ & $.00338^{*}$ & $.01995^{* * *}$ & $.00707^{* * *}$ & $.00473^{* *}$ & $.01852^{* * *}$ \\
\hline & $(.00103)$ & $(.00201)$ & $(.00151)$ & $(.00103)$ & $(.00185)$ & $(.00156)$ \\
\hline \multirow[t]{2}{*}{ L2.Renewable } & $.00714^{* * *}$ & $.00912^{* * *}$ & $.00549^{* * *}$ & $.00689^{* * *}$ & $.00855^{* * *}$ & $.00522^{* * *}$ \\
\hline & $(.00019)$ & $(.00048)$ & $(.00041)$ & $(.00019)$ & $(.00048)$ & $(.00042)$ \\
\hline \multirow[t]{2}{*}{ L2.Conventional } & $-.00152^{* * *}$ & $.00915^{* * *}$ & -.00193 & $.00317^{* * *}$ & $.01197^{* * *}$ & -.00193 \\
\hline & $(.00055)$ & $(.00077)$ & $(.00119)$ & $(.00058)$ & $(.00095)$ & $(.00123)$ \\
\hline \multicolumn{7}{|l|}{ External knowledge: } \\
\hline \multirow[t]{2}{*}{ L2.Storage } & $.00033^{* * *}$ & $7.0 \mathrm{e}-05$ & $.00042^{* * *}$ & $.00041^{* * *}$ & $-.00017^{* *}$ & $.00033^{* * *}$ \\
\hline & $(2.4 \mathrm{e}-05)$ & $(7.0 \mathrm{e}-05)$ & $(5.2 \mathrm{e}-05)$ & $(2.5 \mathrm{e}-05)$ & $(7.2 \mathrm{e}-05)$ & $(6.2 \mathrm{e}-05)$ \\
\hline \multirow[t]{2}{*}{ L2.Renewable } & $-4.0 \mathrm{e}-05^{* * *}$ & $1.0 \mathrm{e}-05$ & $-3.6 \mathrm{e}-05^{* * *}$ & $-8.1 \mathrm{e}-05^{* * *}$ & $-5.0 \mathrm{e}-07$ & $-5.3 \mathrm{e}-05^{* * *}$ \\
\hline & $(4.2 \mathrm{e}-06)$ & $(1.1 \mathrm{e}-05)$ & $(8.8 \mathrm{e}-06)$ & $(4.4 \mathrm{e}-06)$ & $(1.1 \mathrm{e}-05)$ & $(1.1 \mathrm{e}-05)$ \\
\hline \multirow[t]{2}{*}{ L2.Conventional } & $-1.4 \mathrm{e}-05$ & $-6.2 \mathrm{e}-05^{* *}$ & $-2.7 \mathrm{e}-06$ & $.0001^{* * *}$ & $-.00013^{* * *}$ & $-9.5 \mathrm{e}-05^{* * *}$ \\
\hline & $(1.1 \mathrm{e}-05)$ & $(2.8 \mathrm{e}-05)$ & $(2.5 \mathrm{e}-05)$ & $(1.2 \mathrm{e}-05)$ & $(2.9 \mathrm{e}-05)$ & $(3.0 \mathrm{e}-05)$ \\
\hline \multicolumn{7}{|l|}{ Energy prices (firm level): } \\
\hline \multirow[t]{2}{*}{ L1.Coal } & $-.2608^{* * *}$ & $-.374^{* * *}$ & $-1.171^{* * *}$ & $-.7035^{* * *}$ & $-.4901^{* * *}$ & $-1.154^{* * *}$ \\
\hline & $(.02132)$ & $(.05144)$ & $(.05413)$ & $(.03275)$ & $(.08067)$ & $(.07879)$ \\
\hline \multirow[t]{2}{*}{ L1.Electricity } & $-.2512^{* * *}$ & $-.3121^{* * *}$ & $.36^{* * *}$ & $.205^{* * *}$ & .151 & $.4101^{* * *}$ \\
\hline & $(.02367)$ & $(.05696)$ & $(.05581)$ & $(.04911)$ & $(.1107)$ & $(.1288)$ \\
\hline \multicolumn{7}{|c|}{ Economic controls (firm level): } \\
\hline \multirow[t]{2}{*}{ L1.GDP } & $-.03464^{* * *}$ & $-.1851^{* * *}$ & $-.09741^{* * *}$ & $-.1782^{* * *}$ & $-.4919^{* * *}$ & $-.4077^{* * *}$ \\
\hline & $(.00849)$ & $(.01961)$ & $(.02119)$ & $(.02498)$ & $(.05001)$ & $(.05264)$ \\
\hline \multirow[t]{2}{*}{ L1.GDPcap } & $.2733^{* * *}$ & $.2304^{* * *}$ & $.7201^{* * *}$ & $2.603^{* * *}$ & $2.075^{* * *}$ & $4.407^{* * *}$ \\
\hline & $(.03609)$ & $(.08706)$ & $(.1324)$ & $(.1523)$ & $(.3513)$ & $(.3709)$ \\
\hline \multirow[t]{2}{*}{ L1.Popdensity } & $.1228^{* * *}$ & $.1432^{* * *}$ & $.2347^{* * *}$ & $.2274^{* * *}$ & .07829 & $.4256^{* * *}$ \\
\hline & $(.00964)$ & $(.02331)$ & $(.02715)$ & $(.02766)$ & $(.05953)$ & $(.07428)$ \\
\hline Pre-sample history & Yes & Yes & Yes & Yes & Yes & Yes \\
\hline Pre-sample dummy & Yes & Yes & Yes & Yes & Yes & Yes \\
\hline Firm dummy & No & No & No & Yes & Yes & Yes \\
\hline Year trend & Yes & Yes & Yes & Yes & Yes & Yes \\
\hline Country dummy & No & No & No & No & No & No \\
\hline Year x Country dummy & No & No & No & No & No & No \\
\hline Number of observations & 398176 & 398176 & 398176 & 306646 & 306646 & 306646 \\
\hline
\end{tabular}

Significance levels: $\quad{ }^{* * *}: 1 \% \quad{ }^{* *}: 5 \% \quad{ }^{*}: 10 \%$

Note: The top five countries are the US, Japan, Germany, France, and Great Britain. 


\section{B.ii Conventional electricity generation technologies}

Table B.2: Baseline model with intermittent renewable technologies, efficiency-improving fossil fuel technologies and storage technologies.

\begin{tabular}{|c|c|c|c|c|c|c|}
\hline & \multicolumn{6}{|c|}{ Dependent variable: firm-level patents } \\
\hline & \multicolumn{3}{|c|}{ All countries } & \multicolumn{3}{|c|}{ Top five countries } \\
\hline & Renewable & Conventional & Storage & Renewable & Conventional & Storage \\
\hline \multicolumn{7}{|c|}{ Internal knowledge (marginal effects): } \\
\hline \multirow[t]{2}{*}{ L2.Storage } & $.01111^{* * *}$ & $.00523^{\dagger}$ & $-.00763^{* * *}$ & $.01095^{* *}$ & $.00557^{\dagger}$ & $-.00713^{* * *}$ \\
\hline & -0.00401 & -0.00358 & -0.00295 & -0.00428 & -0.00372 & $(.00256)$ \\
\hline \multirow[t]{2}{*}{ L2.Renewable } & $-.00206^{* *}$ & 0.00092 & $.00203^{* * *}$ & $-.00189^{* *}$ & 0.00105 & $.00198^{* * *}$ \\
\hline & -0.00091 & -0.00214 & -0.00056 & -0.00093 & -0.00211 & $(.0006)$ \\
\hline \multirow[t]{2}{*}{ L2.Conventional } & -0.00405 & 0.00014 & -0.00029 & -0.00418 & 0.00073 & -.00019 \\
\hline & -0.00294 & -0.0022 & -0.00552 & -0.00303 & -0.00307 & $(.00536)$ \\
\hline \multicolumn{7}{|l|}{ External knowledge: } \\
\hline \multirow[t]{2}{*}{ L2.Storage } & $.00032^{* *}$ & -.00037 & $9.2 \mathrm{e}-05$ & .00012 & -.00046 & $-.00041^{* *}$ \\
\hline & $(.00016)$ & $(.00026)$ & $(.00018)$ & $(.00018)$ & $(.00028)$ & $(.00021)$ \\
\hline \multirow[t]{2}{*}{ L2.Regionspillover_r } & $-9.5 \mathrm{e}-05^{* * *}$ & $3.9 \mathrm{e}-05$ & $-9.4 \mathrm{e}-06$ & $-5.8 \mathrm{e}-05$ & $5.9 \mathrm{e}-05$ & $9.6 \mathrm{e}-05^{*}$ \\
\hline & $(3.2 \mathrm{e}-05)$ & $(6.1 \mathrm{e}-05)$ & $(3.8 \mathrm{e}-05)$ & $(3.5 \mathrm{e}-05)$ & $(6.5 \mathrm{e}-05)$ & $(5.2 \mathrm{e}-05)$ \\
\hline \multirow{2}{*}{ L2.Renewable } & $-6.1 \mathrm{e}-05$ & -.00014 & -.00011 & -.00011 & -.00015 & $-.00026^{* * *}$ \\
\hline & $(7.1 \mathrm{e}-05)$ & $(9.5 \mathrm{e}-05)$ & $(8.5 \mathrm{e}-05)$ & $(8.2 \mathrm{e}-05)$ & $(.00011)$ & $(8.8 \mathrm{e}-05)$ \\
\hline \multicolumn{7}{|l|}{ Energy prices (firm level): } \\
\hline \multirow[t]{2}{*}{ L1.Coal } & $-.3815^{* *}$ & $-.6727^{* * *}$ & -.1361 & $-.527^{* *}$ & $-.7725^{* * *}$ & -.1086 \\
\hline & $(.1856)$ & $(.2052)$ & $(.2372)$ & $(.2467)$ & $(.2436)$ & $(.3174)$ \\
\hline \multirow[t]{2}{*}{ L1.Electricity } & .1235 & .08159 & .2461 & .1831 & .2901 & $.5878^{*}$ \\
\hline & $(.2658)$ & $(.2688)$ & $(.255)$ & $(.2988)$ & $(.384)$ & $(.3518)$ \\
\hline \multicolumn{7}{|c|}{ Economic controls (firm level): } \\
\hline \multirow[t]{2}{*}{ L1.GDP } & .00419 & $-.1521^{* *}$ & .03875 & $-.1959^{*}$ & -.1383 & .07674 \\
\hline & $(.09369)$ & $(.06199)$ & $(.08106)$ & $(.1065)$ & $(.1047)$ & $(.1629)$ \\
\hline \multirow[t]{2}{*}{ L1.GDPcap } & $1.812^{* *}$ & -.09721 & .0148 & .6323 & .5928 & $-3.465^{*}$ \\
\hline & $(.7971)$ & $(.432)$ & $(1.013)$ & $(.9051)$ & $(.7368)$ & $(1.802)$ \\
\hline \multirow[t]{2}{*}{ L1.Popdensity } & $.1451^{*}$ & -.0176 & $-.332^{* *}$ & -.01769 & .2748 & $-.791^{* * *}$ \\
\hline & $(.08478)$ & $(.1387)$ & $(.1582)$ & $(.1203)$ & $(.1706)$ & $(.2686)$ \\
\hline Pre-sample history & Yes & Yes & Yes & Yes & Yes & Yes \\
\hline Pre-sample dummy & Yes & Yes & Yes & Yes & Yes & Yes \\
\hline Firm FE & Yes & Yes & Yes & Yes & Yes & Yes \\
\hline Year dummy & Yes & Yes & Yes & Yes & Yes & Yes \\
\hline Country dummy & No & No & No & Yes & Yes & Yes \\
\hline Year x Country dummy & No & No & No & No & No & No \\
\hline Number of observations & 33580 & 12310 & 11569 & 27914 & 10002 & 9944 \\
\hline
\end{tabular}

Significance levels: $\quad{ }^{* * *}: 1 \% \quad{ }^{* *}: 5 \% \quad{ }^{*}: 10 \% \quad{ }^{\dagger}: 15 \%$

Note: The top five countries are the US, Japan, Germany, France, and Great Britain. 
Table B.3: Estimates using the list of renewable energy patents compiled by Johnstone et al. (2010).

\begin{tabular}{|c|c|c|c|c|c|c|}
\hline & \multicolumn{6}{|c|}{ Dependent variable: firm-level patents } \\
\hline & \multicolumn{3}{|c|}{ All countries } & \multicolumn{3}{|c|}{ Top five countries } \\
\hline & Renewable & Conventional & Storage & Renewable & Conventional & Storage \\
\hline \multicolumn{7}{|c|}{ Internal knowledge (marginal effects): } \\
\hline \multirow[t]{2}{*}{ L2.Storage } & .00333 & $.00495^{*}$ & $-.00516^{*}$ & .00293 & $.00531^{*}$ & $-.0044^{*}$ \\
\hline & $(.00479)$ & $(.00289)$ & $(.00272)$ & $(.00497)$ & $(.00294)$ & $(.00247)$ \\
\hline \multirow[t]{2}{*}{ L2.Renewable } & -.00028 & $-.00277^{* * *}$ & -.00027 & -.00024 & $-.00311^{* *}$ & $-2.3 \mathrm{e}-05$ \\
\hline & $(.00067)$ & $(.00103)$ & $(.00171)$ & $(.00064)$ & $(.00124)$ & $(.00174)$ \\
\hline \multirow[t]{2}{*}{ L2.Conventional } & $-.00602^{*}$ & .00048 & .00381 & $-.00709^{* *}$ & .00185 & .00414 \\
\hline & $(.00351)$ & $(.002)$ & $(.00644)$ & $(.00359)$ & $(.00235)$ & $(.00641)$ \\
\hline \multicolumn{7}{|l|}{ External knowledge: } \\
\hline \multirow[t]{2}{*}{ L2.Storage } & -.00012 & -.00017 & $2.9 \mathrm{e}-05$ & -.00013 & -.00011 & $-5.1 \mathrm{e}-05$ \\
\hline & $(.00012)$ & $(.00013)$ & $(.00011)$ & $(.00013)$ & $(.00019)$ & $(.00012)$ \\
\hline \multirow[t]{2}{*}{ L2.Renewable } & $-5.1 \mathrm{e}-05^{*}$ & $-8.0 \mathrm{e}-07$ & $-3.9 \mathrm{e}-05$ & $-4.2 \mathrm{e}-05$ & $4.5 \mathrm{e}-07$ & $2.6 \mathrm{e}-06$ \\
\hline & $(2.8 \mathrm{e}-05)$ & $(4.4 \mathrm{e}-05)$ & $(3.1 \mathrm{e}-05)$ & $(3.2 \mathrm{e}-05)$ & $(4.7 \mathrm{e}-05)$ & $(3.0 \mathrm{e}-05)$ \\
\hline \multirow[t]{2}{*}{ L2.Conventional } & $-7.5 \mathrm{e}-05$ & $-9.5 \mathrm{e}-05$ & $2.2 \mathrm{e}-05$ & $-9.3 \mathrm{e}-05$ & $-5.8 \mathrm{e}-05$ & $-2.6 \mathrm{e}-05$ \\
\hline & $(6.2 \mathrm{e}-05)$ & $(.00011)$ & $(9.0 \mathrm{e}-05)$ & $(7.1 \mathrm{e}-05)$ & $(.00014)$ & $(.0001)$ \\
\hline \multicolumn{7}{|l|}{ Energy prices (firm level): } \\
\hline \multirow[t]{2}{*}{ L1.Coal } & -.4281 & $-.5973^{* * *}$ & -.08151 & -.5207 & $-.7968^{* * *}$ & -.0092 \\
\hline & $(.3087)$ & $(.2088)$ & $(.2625)$ & $(.3857)$ & $(.2772)$ & $(.3567)$ \\
\hline \multirow[t]{2}{*}{ L1.Electricity } & .142 & .03851 & .4435 & .1963 & .3012 & .5305 \\
\hline & $(.2644)$ & $(.2212)$ & $(.3088)$ & $(.3392)$ & $(.2782)$ & $(.3821)$ \\
\hline \multicolumn{7}{|c|}{ Economic controls (firm level): } \\
\hline \multirow[t]{2}{*}{ L1.GDP } & .1756 & $-.2321^{* *}$ & $.4449^{* *}$ & -.00193 & $-.3742^{* *}$ & -.08288 \\
\hline & $(.1391)$ & $(.1127)$ & $(.173)$ & $(.1318)$ & $(.1566)$ & $(.2196)$ \\
\hline \multirow[t]{2}{*}{ L1.GDPcap } & -.1733 & .4529 & -.4678 & -.9627 & 1.915 & $-2.563^{* *}$ \\
\hline & $(.9456)$ & $(.6983)$ & $(1.001)$ & $(1.225)$ & $(1.381)$ & $(1.272)$ \\
\hline \multirow[t]{2}{*}{ L1.Popdensity } & .1416 & -.02389 & -.01022 & .01525 & .3474 & -.4382 \\
\hline & $(.1388)$ & $(.125)$ & $(.2689)$ & $(.1847)$ & $(.234)$ & $(.3894)$ \\
\hline Pre-sample history & Yes & Yes & Yes & Yes & Yes & Yes \\
\hline Pre-sample dummy & Yes & Yes & Yes & Yes & Yes & Yes \\
\hline Firm FE & Yes & Yes & Yes & Yes & Yes & Yes \\
\hline Year dummy & Yes & Yes & Yes & Yes & Yes & Yes \\
\hline Country dummy & No & No & No & Yes & Yes & Yes \\
\hline Year x Country dummy & No & No & No & No & No & No \\
\hline Number of observations & 28247 & 12089 & 10306 & 22415 & 9839 & 8906 \\
\hline
\end{tabular}

Significance levels: $\quad{ }^{* * *}: 1 \% \quad{ }^{* *}: 5 \% \quad{ }^{*}: 10 \%$

Note: The top five countries are the US, Japan, Germany, France, and Great Britain. 
Table B.4: Baseline model including all conventional technologies (general and efficiencyimproving).

\begin{tabular}{|c|c|c|c|c|c|c|}
\hline & \multicolumn{6}{|c|}{ Dependent variable: firm-level patents } \\
\hline & \multicolumn{3}{|c|}{ All countries } & \multicolumn{3}{|c|}{ Top five countries } \\
\hline & Renewable & Conventional & Storage & Renewable & Conventional & Storage \\
\hline \multicolumn{7}{|c|}{ Internal knowledge (marginal effects): } \\
\hline \multirow[t]{2}{*}{ L2.Storage } & $.01132^{* * *}$ & .00343 & $-.00757^{* *}$ & $.01111^{* * *}$ & .00345 & $-.0069^{* * *}$ \\
\hline & $(.00365)$ & $(.00402)$ & $(.00296)$ & $(.00387)$ & $(.00404)$ & $(.0026)$ \\
\hline \multirow[t]{2}{*}{ L2.Renewable } & $-.002^{* *}$ & -.00144 & $.00201^{* * *}$ & $-.0018^{* *}$ & -.0012 & $.00195^{* * *}$ \\
\hline & $(.00078)$ & $(.00121)$ & $(.00048)$ & $(.00079)$ & $(.00125)$ & $(.00051)$ \\
\hline \multirow[t]{2}{*}{ L2.Conventional } & -.00041 & $9.1 \mathrm{e}-05$ & $-.0009^{* *}$ & -.00044 & .00012 & $-.00089^{*}$ \\
\hline & $(.00036)$ & $(.00016)$ & $(.00044)$ & $(.00038)$ & $(.00013)$ & $(.00046)$ \\
\hline \multicolumn{7}{|l|}{ External knowledge: } \\
\hline \multirow[t]{2}{*}{ L2.Storage } & $.00032^{*}$ & -.00015 & $5.1 \mathrm{e}-05$ & .00011 & -.00036 & -.00035 \\
\hline & $(.00018)$ & $(.00021)$ & $(.00027)$ & $(.00021)$ & $(.0003)$ & $(.00029)$ \\
\hline \multirow[t]{2}{*}{ L2.Renewable } & $-9.7 \mathrm{e}-05^{* * *}$ & $1.8 \mathrm{e}-07$ & $-2.1 \mathrm{e}-05$ & $-6.6 \mathrm{e}-05^{* *}$ & $1.6 \mathrm{e}-05$ & $6.7 \mathrm{e}-05$ \\
\hline & $(2.7 \mathrm{e}-05)$ & $(4.0 \mathrm{e}-05)$ & $(5.2 \mathrm{e}-05)$ & $(3.0 \mathrm{e}-05)$ & $(4.9 \mathrm{e}-05)$ & $(5.9 \mathrm{e}-05)$ \\
\hline \multirow[t]{2}{*}{ L2.Conventional } & $4.4 \mathrm{e}-06$ & $-2.9 \mathrm{e}-05$ & $-2.7 \mathrm{e}-05$ & $-1.3 \mathrm{e}-05$ & $-4.8 \mathrm{e}-05$ & $-6.1 \mathrm{e}-05$ \\
\hline & $(2.3 \mathrm{e}-05)$ & $(3.1 \mathrm{e}-05)$ & $(3.9 \mathrm{e}-05)$ & $(2.7 \mathrm{e}-05)$ & $(4.3 \mathrm{e}-05)$ & $(4.3 \mathrm{e}-05)$ \\
\hline \multicolumn{7}{|l|}{ Energy prices (firm level): } \\
\hline \multirow[t]{2}{*}{ L1.Coal } & $-.3765^{* *}$ & $-.4755^{* * *}$ & -.1896 & $-.4283^{* *}$ & -.1637 & -.3951 \\
\hline & $(.1485)$ & $(.1787)$ & $(.2319)$ & $(.1916)$ & $(.3225)$ & $(.3112)$ \\
\hline \multirow[t]{2}{*}{ L1.Electricity } & .04421 & .2904 & .08984 & .07068 & .1553 & .3369 \\
\hline & $(.2101)$ & $(.2179)$ & $(.2627)$ & $(.2453)$ & $(.3087)$ & $(.3425)$ \\
\hline \multicolumn{7}{|c|}{ Economic controls (firm level): } \\
\hline \multirow[t]{2}{*}{ L1.GDP } & -.05439 & $-.1555^{*}$ & .1573 & -.09367 & -.1109 & -.2069 \\
\hline & $(.07677)$ & $(.09333)$ & $(.1528)$ & $(.09083)$ & $(.2639)$ & $(.2344)$ \\
\hline \multirow[t]{2}{*}{ L1.GDPcap } & $1.827^{* * *}$ & .8903 & .3442 & .7016 & -.02151 & $-1.458^{* *}$ \\
\hline & $(.6208)$ & $(.6209)$ & $(.8956)$ & $(.7873)$ & $(1.664)$ & $(.7156)$ \\
\hline \multirow[t]{2}{*}{ L1.Popdensity } & $.203^{* * *}$ & -.01789 & -.04555 & .1246 & -.1606 & -.1478 \\
\hline & $(.06968)$ & $(.0797)$ & $(.1607)$ & $(.09675)$ & $(.1485)$ & $(.2284)$ \\
\hline Pre-sample history & Yes & Yes & Yes & Yes & Yes & Yes \\
\hline Pre-sample dummy & Yes & Yes & Yes & Yes & Yes & Yes \\
\hline Firm FE & Yes & Yes & Yes & Yes & Yes & Yes \\
\hline Year dummy & Yes & Yes & Yes & Yes & Yes & Yes \\
\hline Country dummy & No & No & No & Yes & Yes & Yes \\
\hline Year x Country dummy & No & No & No & No & No & No \\
\hline Number of observations & 50689 & 34065 & 11950 & 40930 & 27672 & 10341 \\
\hline
\end{tabular}

Significance levels: $\quad{ }^{* * *}: 1 \% \quad{ }^{* *}: 5 \% \quad{ }^{*}: 10 \%$

Note: The top five countries are the US, Japan, Germany, France, and Great Britain. 
B.iii Alternative specification of energy prices 


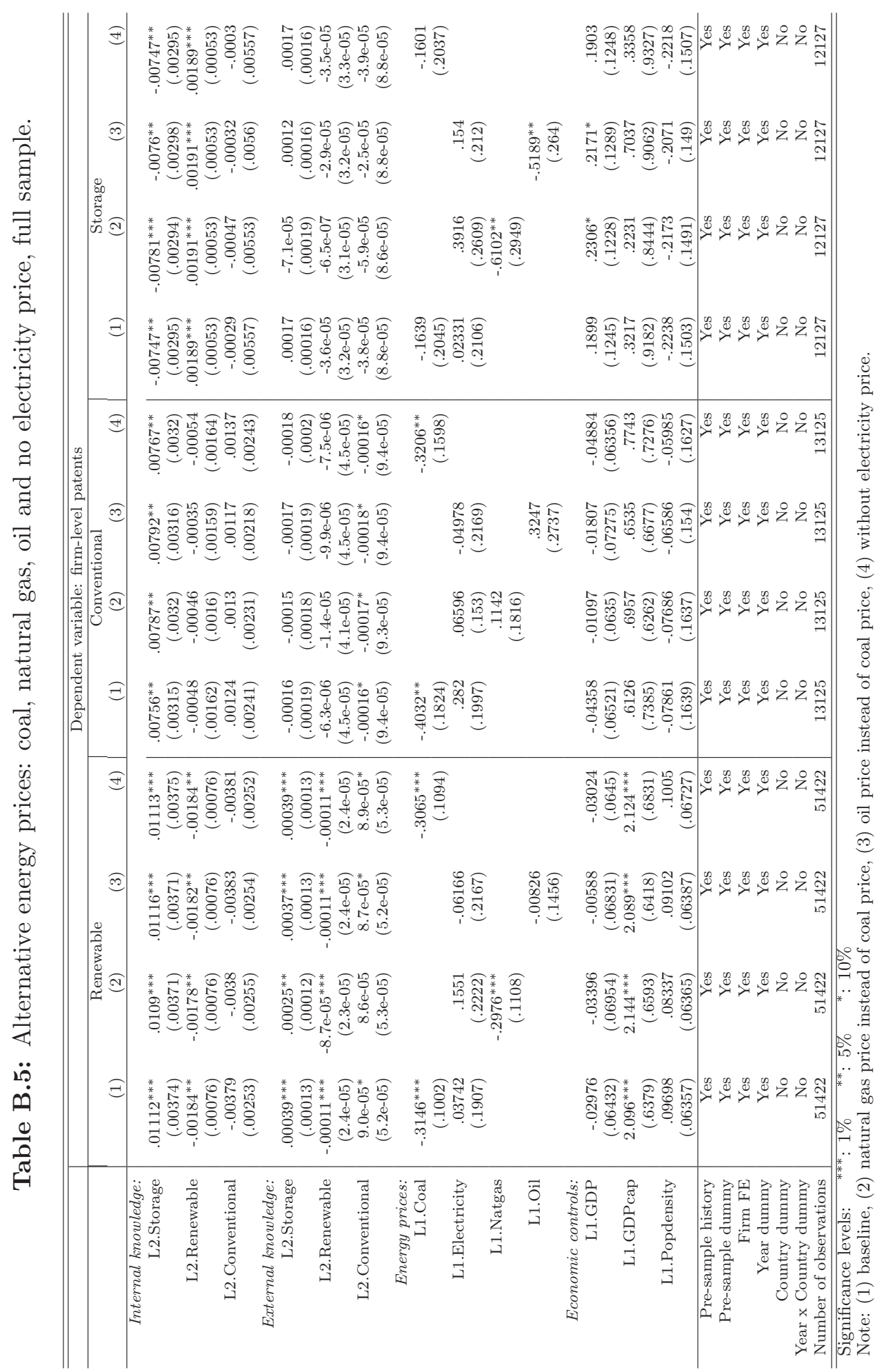




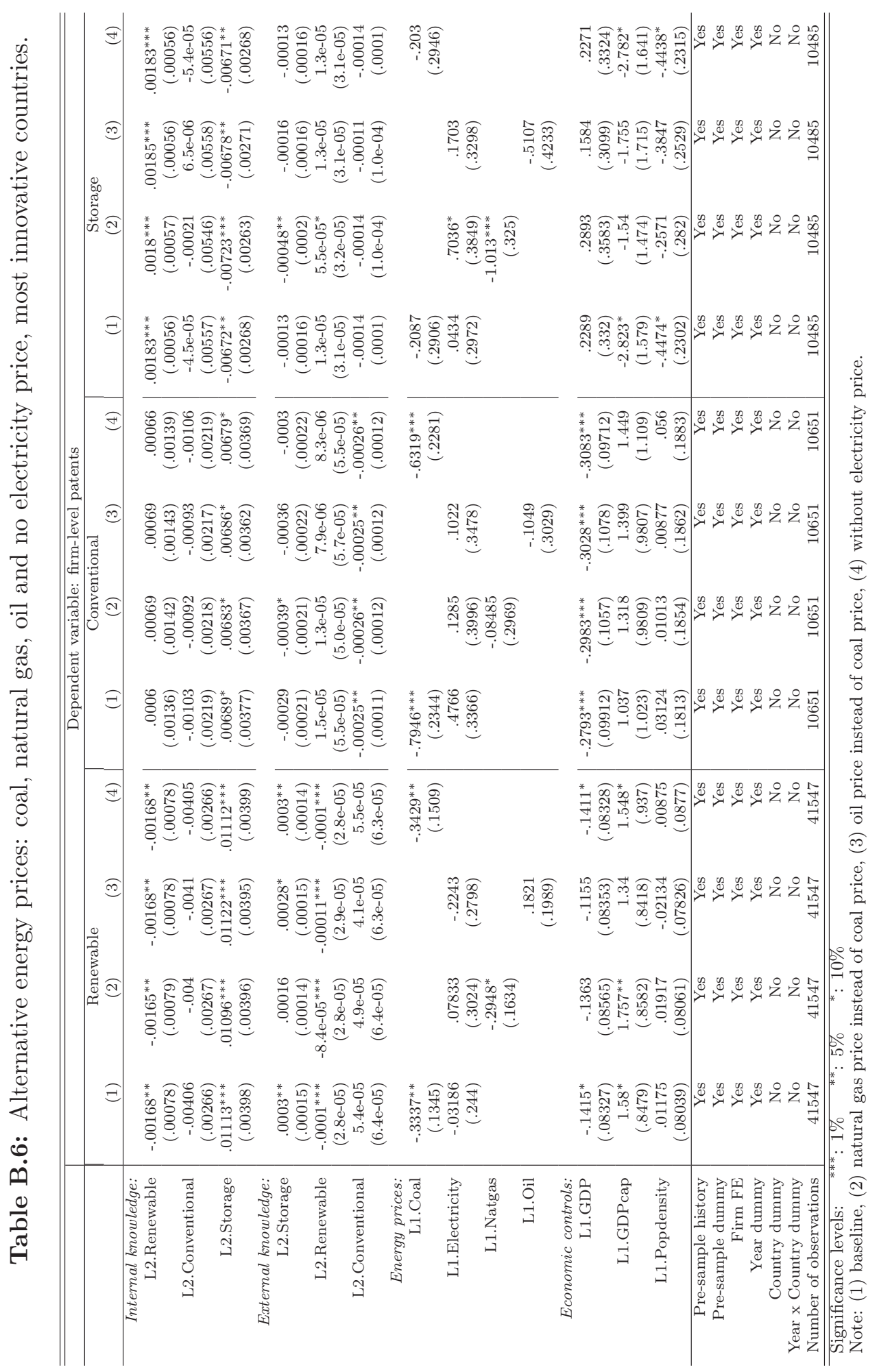




\section{B.iv Research subsidies}

Table B.7: Poisson FE with research subsidies in storage, renewable, general and efficiencyimproving fossil fuels.

\begin{tabular}{|c|c|c|c|c|c|c|}
\hline & \multicolumn{6}{|c|}{ Dependent variable: firm-level patents } \\
\hline & \multicolumn{3}{|c|}{ All countries } & \multicolumn{3}{|c|}{ Top five countries } \\
\hline & Renewable & Conventional & Storage & Renewable & Conventional & Storage \\
\hline \multicolumn{7}{|c|}{ Internal knowledge (marginal effects): } \\
\hline \multirow[t]{2}{*}{ L2.Storage } & $.00727^{*}$ & .00574 & -.0031 & $.00688^{*}$ & .00544 & -.00329 \\
\hline & $(.00408)$ & $(.00369)$ & $(.00198)$ & $(.00408)$ & $(.00379)$ & $(.00202)$ \\
\hline \multirow[t]{2}{*}{ L2.Renewable } & -.00031 & -.00045 & $.00115^{*}$ & -.00024 & -.00055 & .00115 \\
\hline & $(.0007)$ & $(.00136)$ & $(.00068)$ & $(.0007)$ & $(.00126)$ & $(.0007)$ \\
\hline \multirow[t]{2}{*}{ L2.Conventional } & -.00448 & $-.00531^{* * *}$ & -.00275 & $-.00484^{*}$ & $-.00631^{* * *}$ & -.00239 \\
\hline & $(.00274)$ & $(.00151)$ & $(.00341)$ & $(.00289)$ & $(.00171)$ & $(.00354)$ \\
\hline \multicolumn{7}{|l|}{ External knowledge: } \\
\hline \multirow[t]{2}{*}{ L2.Storage } & .00049 & $5.6 \mathrm{e}-06$ & -.00034 & .00044 & .00013 & -.00037 \\
\hline & $(.0003)$ & $(.00023)$ & $(.00038)$ & $(.00031)$ & $(.00028)$ & $(.00039)$ \\
\hline \multirow[t]{2}{*}{ L2.Renewable } & $-.00011^{*}$ & $-5.4 \mathrm{e}-05$ & $-6.7 \mathrm{e}-07$ & $-.0001^{*}$ & $-5.2 \mathrm{e}-05$ & $2.4 \mathrm{e}-05$ \\
\hline & $(5.9 \mathrm{e}-05)$ & $(5.6 \mathrm{e}-05)$ & $(8.0 \mathrm{e}-05)$ & $(6.0 \mathrm{e}-05)$ & $(6.4 \mathrm{e}-05)$ & $(8.4 \mathrm{e}-05)$ \\
\hline \multirow[t]{2}{*}{ L2.Conventional } & .00015 & $3.1 \mathrm{e}-05$ & $-3.7 \mathrm{e}-05$ & .00013 & $-7.3 \mathrm{e}-06$ & $-7.6 \mathrm{e}-05$ \\
\hline & $(.00012)$ & $(.00011)$ & $(.00017)$ & $(.00012)$ & $(.00012)$ & $(.00018)$ \\
\hline \multicolumn{7}{|l|}{ Energy prices (firm level): } \\
\hline \multirow[t]{2}{*}{ L1.Coal } & -.06449 & -.1547 & .08699 & -.07082 & -.1387 & -.1151 \\
\hline & $(.2154)$ & $(.3604)$ & $(.4266)$ & $(.2267)$ & $(.4399)$ & $(.4636)$ \\
\hline \multirow[t]{2}{*}{ L1.Electricity } & .08696 & $-.835^{* *}$ & -.749 & .1883 & -.7264 & -.3306 \\
\hline & $(.3801)$ & $(.3362)$ & $(.46)$ & $(.4132)$ & $(.4553)$ & $(.5156)$ \\
\hline \multicolumn{7}{|c|}{ Economic controls (firm level): } \\
\hline \multirow[t]{2}{*}{ L1.GDP } & $-.4585^{* *}$ & $-.3476^{*}$ & $-1.263^{* * *}$ & $-.4536^{* *}$ & -.2684 & $-1.313^{* * *}$ \\
\hline & $(.1848)$ & $(.1795)$ & $(.4261)$ & $(.1898)$ & $(.2436)$ & $(.4075)$ \\
\hline \multirow[t]{2}{*}{ L1.GDPcap } & $3.654^{* *}$ & .7386 & $4.531^{* *}$ & $3.138^{*}$ & -.9604 & 3.907 \\
\hline & $(1.442)$ & $(1.166)$ & $(2.147)$ & $(1.665)$ & $(2.257)$ & $(2.616)$ \\
\hline \multirow[t]{2}{*}{ L1.Popdensity } & $.1754^{*}$ & .1005 & .2311 & $.2269^{* *}$ & -.1612 & .1286 \\
\hline & $(.09785)$ & $(.144)$ & $(.2984)$ & $(.1008)$ & $(.326)$ & $(.3656)$ \\
\hline \multicolumn{7}{|c|}{ Research subsidies (firm level): } \\
\hline \multirow[t]{2}{*}{ L1.Storage } & -.05525 & -.04703 & $.2784^{* * *}$ & -.07564 & -.03147 & $.272^{* * *}$ \\
\hline & $(.07473)$ & $(.08809)$ & $(.09911)$ & $(.07279)$ & $(.1024)$ & $(.1055)$ \\
\hline \multirow[t]{2}{*}{ L1.Renewable } & .09807 & -.05494 & $.6138^{* *}$ & .1602 & .02738 & $.7445^{* * *}$ \\
\hline & $(.1511)$ & $(.1741)$ & $(.2681)$ & $(.1526)$ & $(.2157)$ & $(.2733)$ \\
\hline \multirow[t]{2}{*}{ L1.Efficiency } & $.1314^{*}$ & .1548 & $.384^{* *}$ & $.1274^{*}$ & .09584 & $.3561^{* *}$ \\
\hline & $(.07502)$ & $(.1346)$ & $(.1528)$ & $(.07678)$ & $(.1316)$ & $(.1635)$ \\
\hline Pre-sample history & Yes & Yes & Yes & Yes & Yes & Yes \\
\hline Pre-sample dummy & Yes & Yes & Yes & Yes & Yes & Yes \\
\hline Firm FE & Yes & Yes & Yes & Yes & Yes & Yes \\
\hline Year dummy & Yes & Yes & Yes & Yes & Yes & Yes \\
\hline Country dummy & No & No & No & Yes & Yes & Yes \\
\hline Year x Country dummy & No & No & No & No & No & No \\
\hline Number of observations & 2768 & 2721 & 2724 & 2600 & 2554 & 2545 \\
\hline
\end{tabular}

Note: The top five countries are the US, Japan, Germany, France, and Great Britain. 


\section{B.v Timing of innovation}

Next, we consider two issues related to our lag structure. First, we consider one- and three-year lags for internal and external knowledge stocks, as our baseline estimates include a two-year lag for the internal and external knowledge stocks, whereas energy prices and macroeconomic indicators are lagged one year. The results show that the coefficient estimates become slightly more precise as we increase the number of lags, suggesting that it might take a few years after filing a patent for the effect of the new knowledge to materialize in new patents filed (Tables B.8 and B.9). Other than this, the lag structure does not significantly affect our main findings.

A second issue related to the timing of innovation is that patent data often present a serious truncation bias due to the lag between patent application and patent granted. To analyze whether the registration delay in the USPTO plays a role in our analysis, we explore three different solutions. First, we drop the last four, five, and six years of the data, respectively. While our results are robust to dropping the last four years of the data, Table B.10 shows that when we drop the last five years of data, storage technologies only significantly benefit renewable technologies. Hence, the finding that better storage technologies benefit conventional technologies is driven by the filed patent applications in recent years. The second option is to correct for the patent truncation bias following Hall et al. (2005), as described in Appendix A.iv. Table B.11, which presents estimation results when we use data corrected for the patent truncation problem, shows that our main results hold. ${ }^{3}$ Finally, we expand our data set with three additional years using OECD's 2016 Patent Database. ${ }^{4}$ As before, we estimate our baseline specification excluding the last two, three, four and five years to account for the USPTO lag (without truncation correction). These new estimation results in Table B.12 confirm the positive effect of innovation on storage in both renewable and conventional technologies (with or without the five year lag).

\footnotetext{
${ }^{3}$ Note, that we only correct for the patent truncation problem in table B.11. The reason is that the truncation correction weights may be subject to some measurement errors (Hall et al., 2005). Specifically, our raw data provides one patent application date per family id instead of per patent id. This means that for some patent applications in our data set the lag between patent application and patent granted is larger than in reality.

${ }^{4}$ We focus on the most innovative firms (defined as firms with more than 15 patents in total), which includes data on the 565 most innovative firms located across the world from 1978 to 2014.
} 
Table B.8: Baseline model using one-year lags (L1).

\begin{tabular}{|c|c|c|c|c|c|c|}
\hline & \multicolumn{6}{|c|}{ Dependent variable: firm-level patents } \\
\hline & \multicolumn{3}{|c|}{ All countries } & \multicolumn{3}{|c|}{ Top five countries } \\
\hline & Renewable & Conventional & Storage & Renewable & Conventional & Storage \\
\hline \multicolumn{7}{|c|}{ Internal knowledge (marginal effects): } \\
\hline \multirow[t]{2}{*}{ L1.Storage } & $.00862^{* * *}$ & $.0076^{* *}$ & $-.00589^{* *}$ & $.00823^{* * *}$ & $.00784^{* *}$ & $-.0055^{* *}$ \\
\hline & $(.00303)$ & $(.00348)$ & $(.00239)$ & $(.00313)$ & $(.0037)$ & $(.00223)$ \\
\hline \multirow{2}{*}{ L1.Renewable } & -.00038 & .00023 & $.00228^{* * *}$ & -.00021 & .00066 & $.00218^{* * *}$ \\
\hline & $(.00055)$ & $(.00159)$ & $(.00052)$ & $(.00056)$ & $(.00137)$ & $(.00055)$ \\
\hline \multirow[t]{2}{*}{ L1.Conventional } & -.00257 & .0029 & -.00092 & -.00304 & .0024 & -.00069 \\
\hline & $(.00242)$ & $(.00216)$ & $(.00592)$ & $(.00258)$ & $(.00205)$ & $(.00606)$ \\
\hline \multicolumn{7}{|l|}{ External knowledge: } \\
\hline \multirow[t]{2}{*}{ L1.Storage } & $.00041^{* * *}$ & -.00024 & .00023 & $.00028^{*}$ & -.0003 & -.00011 \\
\hline & $(.00013)$ & $(.00023)$ & $(.00019)$ & $(.00015)$ & $(.00025)$ & $(.0002)$ \\
\hline \multirow[t]{2}{*}{ L1.Renewable } & $-.00012^{* * *}$ & $8.3 \mathrm{e}-06$ & $-7.1 \mathrm{e}-05$ & $-9.7 \mathrm{e}-05^{* * *}$ & $2.7 \mathrm{e}-05$ & $6.4 \mathrm{e}-07$ \\
\hline & $(2.5 \mathrm{e}-05)$ & $(5.3 \mathrm{e}-05)$ & $(4.7 \mathrm{e}-05)$ & $(3.0 \mathrm{e}-05)$ & $(5.6 \mathrm{e}-05)$ & $(5.7 \mathrm{e}-05)$ \\
\hline \multirow[t]{2}{*}{ L1.Conventional } & $7.5 \mathrm{e}-05$ & -.00019 & $-3.3 \mathrm{e}-05$ & $1.7 \mathrm{e}-05$ & -.00014 & -.00017 \\
\hline & $(4.8 \mathrm{e}-05)$ & $(.00012)$ & $(.0001)$ & $(5.6 \mathrm{e}-05)$ & $(.00012)$ & $(.00011)$ \\
\hline \multicolumn{7}{|l|}{ Energy prices (firm level): } \\
\hline \multirow[t]{2}{*}{ L1.Coal } & $-.2976^{*}$ & $-.5052^{* *}$ & -.1456 & $-.3733^{*}$ & $-.788^{* * *}$ & -.193 \\
\hline & $(.1678)$ & $(.2181)$ & $(.234)$ & $(.2213)$ & $(.2426)$ & $(.3007)$ \\
\hline \multirow[t]{2}{*}{ L1.Electricity } & -.01517 & .1002 & .154 & .09021 & $.5604^{*}$ & .4198 \\
\hline & $(.203)$ & $(.2627)$ & $(.2682)$ & $(.2376)$ & $(.321)$ & $(.3529)$ \\
\hline \multicolumn{7}{|c|}{ Economic controls (firm level): } \\
\hline \multirow[t]{2}{*}{ L1.GDP } & .1229 & -.1314 & .2051 & .01348 & -.2139 & .00794 \\
\hline & $(.07844)$ & $(.08324)$ & $(.1683)$ & $(.1118)$ & $(.1625)$ & $(.2489)$ \\
\hline \multirow[t]{2}{*}{ L1.GDPcap } & $1.642^{* *}$ & .4052 & .5754 & .4759 & .8646 & $-2.533^{*}$ \\
\hline & $(.6697)$ & $(.5712)$ & $(1.125)$ & $(1.021)$ & $(1.287)$ & $(1.532)$ \\
\hline \multirow[t]{2}{*}{ L1.Popdensity } & .00198 & -.02913 & -.2498 & -.1613 & .0235 & $-.7259^{* * *}$ \\
\hline & $(.07603)$ & $(.1238)$ & $(.2088)$ & $(.1076)$ & $(.16)$ & $(.1959)$ \\
\hline Pre-sample history & Yes & Yes & Yes & Yes & Yes & Yes \\
\hline Pre-sample dummy & Yes & Yes & Yes & Yes & Yes & Yes \\
\hline Firm FE & Yes & Yes & Yes & Yes & Yes & Yes \\
\hline Year dummy & Yes & Yes & Yes & Yes & Yes & Yes \\
\hline Country dummy & No & No & No & Yes & Yes & Yes \\
\hline Year x Country dummy & No & No & No & No & No & No \\
\hline Number of observations & 42594 & 11756 & 10766 & 34688 & 9575 & 9356 \\
\hline
\end{tabular}

Significance levels: $\quad{ }^{* * *}: 1 \% \quad{ }^{* *}: 5 \% \quad{ }^{*}: 10 \%$

Note: The top five countries are the US, Japan, Germany, France, and Great Britain. 
Table B.9: Baseline model using three-year lags (L3).

\begin{tabular}{|c|c|c|c|c|c|c|}
\hline & \multicolumn{6}{|c|}{ Dependent variable: firm-level patents } \\
\hline & \multicolumn{3}{|c|}{ All countries } & \multicolumn{3}{|c|}{ Top five countries } \\
\hline & Renewable & Conventional & Storage & Renewable & Conventional & Storage \\
\hline \multicolumn{7}{|c|}{ Internal knowledge (marginal effects): } \\
\hline L3.Storage & $\begin{array}{l}.01102^{* * *} \\
(.00321)\end{array}$ & $\begin{array}{l}.00702^{* *} \\
(.00311)\end{array}$ & $\begin{array}{c}-.00952^{* * *} \\
(.00357)\end{array}$ & $\begin{array}{c}.01092^{* * *} \\
(.00344)\end{array}$ & $\begin{array}{l}.00624^{*} \\
(.00321)\end{array}$ & $\begin{array}{c}-.00868^{* * *} \\
(.00314)\end{array}$ \\
\hline L3.Renewable & $\begin{array}{c}-.00307^{* * *} \\
(.00101)\end{array}$ & $\begin{array}{l}-.00066 \\
(.00175)\end{array}$ & $\begin{array}{l}.00137^{* *} \\
(.00057)\end{array}$ & $\begin{array}{c}-.00278^{* * *} \\
(.00102)\end{array}$ & $\begin{array}{c}-4.2 \mathrm{e}-05 \\
(.0016)\end{array}$ & $\begin{array}{l}.00137^{* *} \\
(.00062)\end{array}$ \\
\hline L3.Conventional & $\begin{array}{l}-.0047^{*} \\
(.00275)\end{array}$ & $\begin{array}{l}-.00157 \\
(.00204)\end{array}$ & $\begin{array}{l}-.00276 \\
(.00427)\end{array}$ & $\begin{array}{l}-.00477^{*} \\
(.00284)\end{array}$ & $\begin{array}{l}-.00145 \\
(.00264)\end{array}$ & $\begin{array}{c}-.0024 \\
(.00422)\end{array}$ \\
\hline \multicolumn{7}{|l|}{ External knowledge: } \\
\hline L3.Storage & $\begin{array}{l}.00034^{* *} \\
(.00013)\end{array}$ & $\begin{array}{l}-.00037^{*} \\
(.00022)\end{array}$ & $\begin{array}{c}.00024 \\
(.00016)\end{array}$ & $\begin{array}{c}.0002 \\
(.00015)\end{array}$ & $\begin{array}{c}-.00048^{* *} \\
(.00023)\end{array}$ & $\begin{array}{l}-6.1 \mathrm{e}-05 \\
(.00016)\end{array}$ \\
\hline L3.Renewable & $\begin{array}{c}-9.3 \mathrm{e}-05^{* * *} \\
(2.4 \mathrm{e}-05)\end{array}$ & $\begin{array}{c}5.2 \mathrm{e}-05 \\
(5.2 \mathrm{e}-05)\end{array}$ & $\begin{array}{l}-3.8 \mathrm{e}-05 \\
(3.0 \mathrm{e}-05)\end{array}$ & $\begin{array}{c}-7.2 \mathrm{e}-05^{* *} \\
(2.9 \mathrm{e}-05)\end{array}$ & $\begin{array}{c}6.6 \mathrm{e}-05 \\
(5.6 \mathrm{e}-05)\end{array}$ & $\begin{array}{c}1.8 \mathrm{e}-05 \\
(2.6 \mathrm{e}-05)\end{array}$ \\
\hline L3.Conventional & $\begin{array}{c}7.1 \mathrm{e}-05 \\
(6.8 \mathrm{e}-05)\end{array}$ & $\begin{array}{l}-.00018 \\
(.00012)\end{array}$ & $\begin{array}{c}-7.4 \mathrm{e}-06 \\
(9.9 \mathrm{e}-05)\end{array}$ & $\begin{array}{c}3.9 \mathrm{e}-05 \\
(8.0 \mathrm{e}-05)\end{array}$ & $\begin{array}{l}-.00023 \\
(.00015)\end{array}$ & $\begin{array}{l}-9.1 \mathrm{e}-05 \\
(.00011)\end{array}$ \\
\hline \multicolumn{7}{|l|}{ Energy prices (firm level): } \\
\hline L1.Coal & $\begin{array}{c}-.4039^{* * *} \\
(.1364)\end{array}$ & $\begin{array}{c}-.6567^{* * *} \\
(.2286)\end{array}$ & $\begin{array}{l}-.2328 \\
(.2347)\end{array}$ & $\begin{array}{c}-.4883^{* * *} \\
(.1777)\end{array}$ & $\begin{array}{c}-.915^{* * *} \\
(.2509)\end{array}$ & $\begin{array}{l}-.2827 \\
(.3161)\end{array}$ \\
\hline L1.Electricity & $\begin{array}{c}.1895 \\
(.1906)\end{array}$ & $\begin{array}{l}.1087 \\
(.229)\end{array}$ & $\begin{array}{c}.192 \\
(.253)\end{array}$ & $\begin{array}{l}.2341 \\
(.231)\end{array}$ & $\begin{array}{c}.4544 \\
(.2809)\end{array}$ & $\begin{array}{c}.3517 \\
(.3679)\end{array}$ \\
\hline \multicolumn{7}{|c|}{ Economic controls (firm level): } \\
\hline L1.GDP & $\begin{array}{l}-.02071 \\
(.08959)\end{array}$ & $\begin{array}{c}-.2165^{* *} \\
(.0917)\end{array}$ & $\begin{array}{l}.1374 \\
(.146)\end{array}$ & $\begin{array}{l}-.1426 \\
(.1169)\end{array}$ & $\begin{array}{r}-.06136 \\
(.1349)\end{array}$ & $\begin{array}{r}-.01096 \\
(.2546)\end{array}$ \\
\hline L1.GDPcap & $\begin{array}{l}1.439^{*} \\
(.8191)\end{array}$ & $\begin{array}{c}.2754 \\
(.5862)\end{array}$ & $\begin{array}{l}.3503 \\
(.9785)\end{array}$ & $\begin{array}{c}.35 \\
(1.11)\end{array}$ & $\begin{array}{l}-.9668 \\
(.9452)\end{array}$ & $\begin{array}{l}-2.538^{*} \\
(1.368)\end{array}$ \\
\hline L1.Popdensity & $\begin{array}{c}.1596^{* *} \\
(.06852) \\
\end{array}$ & $\begin{array}{l}.05734 \\
(.1263) \\
\end{array}$ & $\begin{array}{l}-.1453 \\
(.1509) \\
\end{array}$ & $\begin{array}{l}.00681 \\
(.1057) \\
\end{array}$ & $\begin{array}{l}.04555 \\
(.1646) \\
\end{array}$ & $\begin{array}{c}-.4822^{* *} \\
(.2304) \\
\end{array}$ \\
\hline Pre-sample history & Yes & Yes & Yes & Yes & Yes & Yes \\
\hline Pre-sample dummy & Yes & Yes & Yes & Yes & Yes & Yes \\
\hline Firm FE & Yes & Yes & Yes & Yes & Yes & Yes \\
\hline Year dummy & Yes & Yes & Yes & Yes & Yes & Yes \\
\hline Country dummy & No & No & No & Yes & Yes & Yes \\
\hline Year x Country dummy & No & No & No & No & No & No \\
\hline Number of observations & 58600 & 13944 & 13119 & 47043 & 11301 & 11280 \\
\hline
\end{tabular}

Significance levels: $\quad{ }^{* * *}: 1 \% \quad{ }^{* *}: 5 \% \quad{ }^{*}: 10 \%$

Note: The top five countries are the US, Japan, Germany, France, and Great Britain. 
Table B.10: Baseline specification estimates using data from 1978 to 2006 .

\begin{tabular}{|c|c|c|c|c|c|c|}
\hline & \multicolumn{6}{|c|}{ Dependent variable: firm-level patents } \\
\hline & \multicolumn{3}{|c|}{ All countries } & \multicolumn{3}{|c|}{ Top five countries } \\
\hline & Renewable & Conventional & Storage & Renewable & Conventional & Storage \\
\hline \multicolumn{7}{|c|}{ Internal knowledge (marginal effects): } \\
\hline L2.Storage & $\begin{array}{c}.01323^{* * *} \\
(.00416)\end{array}$ & $\begin{array}{c}.00449 \\
(.00491)\end{array}$ & $\begin{array}{c}-.01239^{* * *} \\
(.00354)\end{array}$ & $\begin{array}{c}.01291^{* * *} \\
(.00429)\end{array}$ & $\begin{array}{c}.00552 \\
(.00526)\end{array}$ & $\begin{array}{c}-.01132^{* * *} \\
(.00315)\end{array}$ \\
\hline L2.Renewable & $\begin{array}{c}-.00203^{* * *} \\
(.00078)\end{array}$ & $\begin{array}{c}-.0008 \\
(.00165)\end{array}$ & $\begin{array}{c}.00169^{* *} \\
(.0007)\end{array}$ & $\begin{array}{c}-.00185^{* *} \\
(.00078)\end{array}$ & $\begin{array}{c}-.001 \\
(.00172)\end{array}$ & $\begin{array}{l}.00164^{* *} \\
(.00073)\end{array}$ \\
\hline L2.Conventional & $\begin{array}{l}-.00417 \\
(.00298)\end{array}$ & $\begin{array}{c}.00071 \\
(.00214)\end{array}$ & $\begin{array}{l}-.00066 \\
(.00614)\end{array}$ & $\begin{array}{l}-.00433 \\
(.00309)\end{array}$ & $\begin{array}{c}.00256 \\
(.00277)\end{array}$ & $\begin{array}{c}-.00024 \\
(.0063)\end{array}$ \\
\hline \multicolumn{7}{|l|}{ External knowledge: } \\
\hline L2.Storage & $\begin{array}{l}.00024^{*} \\
(.00014)\end{array}$ & $\begin{array}{c}2.5 \mathrm{e}-05 \\
(.00019)\end{array}$ & $\begin{array}{l}.00044^{* *} \\
(.00019)\end{array}$ & $\begin{array}{c}.00016 \\
(.00015)\end{array}$ & $\begin{array}{c}-3.9 \mathrm{e}-05 \\
(.0002)\end{array}$ & $\begin{array}{c}.00011 \\
(.00019)\end{array}$ \\
\hline L2.Renewable & $\begin{array}{c}-7.8 \mathrm{e}-05^{* * *} \\
(2.5 \mathrm{e}-05)\end{array}$ & $\begin{array}{l}-4.3 \mathrm{e}-05 \\
(4.8 \mathrm{e}-05)\end{array}$ & $\begin{array}{c}-.00012^{* * *} \\
(4.3 \mathrm{e}-05)\end{array}$ & $\begin{array}{c}-7.4 \mathrm{e}-05^{* * *} \\
(2.8 \mathrm{e}-05)\end{array}$ & $\begin{array}{l}-3.8 \mathrm{e}-05 \\
(4.8 \mathrm{e}-05)\end{array}$ & $\begin{array}{l}-5.3 \mathrm{e}-05 \\
(4.9 \mathrm{e}-05)\end{array}$ \\
\hline L2.Conventional & $\begin{array}{l}-3.3 \mathrm{e}-05 \\
(5.4 \mathrm{e}-05)\end{array}$ & $\begin{array}{c}-8.6 \mathrm{e}-05 \\
(.0001)\end{array}$ & $\begin{array}{l}-1.9 \mathrm{e}-06 \\
(9.2 \mathrm{e}-05)\end{array}$ & $\begin{array}{l}-6.3 \mathrm{e}-05 \\
(6.1 \mathrm{e}-05)\end{array}$ & $\begin{array}{l}-1.8 \mathrm{e}-05 \\
(.00012)\end{array}$ & $\begin{array}{l}-8.4 \mathrm{e}-05 \\
(9.9 \mathrm{e}-05)\end{array}$ \\
\hline \multicolumn{7}{|l|}{ Energy prices (firm level): } \\
\hline L1.Coal & $\begin{array}{c}-.3588^{* *} \\
(.1621)\end{array}$ & $\begin{array}{c}-.6647^{* * *} \\
(.2443)\end{array}$ & $\begin{array}{l}.01895 \\
(.2288)\end{array}$ & $\begin{array}{c}-.4558^{* *} \\
(.216)\end{array}$ & $\begin{array}{c}-.744^{* * *} \\
(.2365)\end{array}$ & $\begin{array}{l}.01624 \\
(.3025)\end{array}$ \\
\hline L1.Electricity & $\begin{array}{c}.1031 \\
(.2079)\end{array}$ & $\begin{array}{l}-.1268 \\
(.2789)\end{array}$ & $\begin{array}{c}.1092 \\
(.2688)\end{array}$ & $\begin{array}{c}.1356 \\
(.2409)\end{array}$ & $\begin{array}{l}.06639 \\
(.3466)\end{array}$ & $\begin{array}{c}.2706 \\
(.3742)\end{array}$ \\
\hline \multicolumn{7}{|c|}{ Economic controls (firm level): } \\
\hline L1.GDP & $\begin{array}{c}-.128 \\
(.08844)\end{array}$ & $\begin{array}{c}-.3346^{* * *} \\
(.07777)\end{array}$ & $\begin{array}{l}.3246^{*} \\
(.1681)\end{array}$ & $\begin{array}{c}-.223^{* *} \\
(.09357)\end{array}$ & $\begin{array}{c}-.4003^{* * *} \\
(.1135)\end{array}$ & $\begin{array}{l}.08523 \\
(.2595)\end{array}$ \\
\hline L1.GDPcap & $\begin{array}{c}1.55^{* *} \\
(.7725)\end{array}$ & $\begin{array}{c}.8078 \\
(.6162)\end{array}$ & $\begin{array}{l}.6887 \\
(1.35)\end{array}$ & $\begin{array}{c}.8579 \\
(.8111)\end{array}$ & $\begin{array}{c}2.079^{*} \\
(1.114)\end{array}$ & $\begin{array}{l}-1.904 \\
(1.564)\end{array}$ \\
\hline L1.Popdensity & $\begin{array}{l}.1818^{* * *} \\
(.07055)\end{array}$ & $\begin{array}{c}-.00405 \\
(.141)\end{array}$ & $\begin{array}{l}-.1458 \\
(.1982)\end{array}$ & $\begin{array}{c}.1401 \\
(.09992)\end{array}$ & $\begin{array}{c}.2532 \\
(.1691)\end{array}$ & $\begin{array}{c}-.6342^{* *} \\
(.3054)\end{array}$ \\
\hline Pre-sample history & Yes & Yes & Yes & Yes & Yes & Yes \\
\hline Pre-sample dummy & Yes & Yes & Yes & Yes & Yes & Yes \\
\hline Firm FE & Yes & Yes & Yes & Yes & Yes & Yes \\
\hline Year dummy & Yes & Yes & Yes & Yes & Yes & Yes \\
\hline Country dummy & No & No & No & Yes & Yes & Yes \\
\hline Year x Country dummy & No & No & No & No & No & No \\
\hline Number of observations & 48212 & 12262 & 10877 & 39096 & 9956 & 9391 \\
\hline
\end{tabular}

Significance levels: $\quad{ }^{* * *}: 1 \% \quad{ }^{* *}: 5 \% \quad{ }^{*}: 10 \%$

Note: The top five countries are the US, Japan, Germany, France, and Great Britain. 
Table B.11: Baseline specification with patents from 2004 to 2011 adjusted for patent truncation bias.

\begin{tabular}{|c|c|c|c|c|c|c|}
\hline & \multicolumn{6}{|c|}{ Dependent variable: firm-level patents } \\
\hline & \multicolumn{3}{|c|}{ All countries } & \multicolumn{3}{|c|}{\begin{tabular}{|l|} 
Top five countries \\
\end{tabular}} \\
\hline & Renewable & Conventional & Storage & Renewable & Conventional & Storage \\
\hline \multicolumn{7}{|c|}{ Internal knowledge (marginal effects): } \\
\hline \multirow[t]{2}{*}{ L2.Storage } & $.01043^{* * *}$ & $.00693^{* *}$ & $-.00679^{* *}$ & $.01043^{* * *}$ & $.00658^{* *}$ & $-.00599^{* *}$ \\
\hline & $(.00347)$ & $(.00284)$ & $(.00294)$ & $(.00368)$ & $(.00301)$ & $(.00263)$ \\
\hline \multirow[t]{2}{*}{ L2.Renewable } & $-.00183^{* *}$ & -.00019 & $.00188^{* * *}$ & $-.00164^{* *}$ & .00059 & $.00178^{* * *}$ \\
\hline & $(.00077)$ & $(.00165)$ & $(.00052)$ & $(.00078)$ & $(.00136)$ & $(.00056)$ \\
\hline \multirow[t]{2}{*}{ L2.Conventional } & -.00291 & .0005 & -.00044 & -.00299 & -.00046 & $4.9 \mathrm{e}-05$ \\
\hline & $(.0024)$ & $(.00192)$ & $(.00539)$ & $(.00254)$ & $(.00207)$ & $(.00533)$ \\
\hline \multicolumn{7}{|l|}{ External knowledge: } \\
\hline \multirow[t]{2}{*}{ L2.Storage } & $.00029^{* *}$ & -.00015 & .00014 & .00017 & -.00021 & -.00015 \\
\hline & $(.00012)$ & $(.00021)$ & $(.00014)$ & $(.00013)$ & $(.00021)$ & $(.00015)$ \\
\hline \multirow[t]{2}{*}{ L2.Renewable } & $-8.2 \mathrm{e}-05^{* * *}$ & $5.9 \mathrm{e}-06$ & $-2.4 \mathrm{e}-05$ & $-6.6 \mathrm{e}-05^{* * *}$ & $1.3 \mathrm{e}-05$ & $3.0 \mathrm{e}-05$ \\
\hline & $(2.0 \mathrm{e}-05)$ & $(4.7 \mathrm{e}-05)$ & $(2.5 \mathrm{e}-05)$ & $(2.3 \mathrm{e}-05)$ & $(5.1 \mathrm{e}-05)$ & $(2.4 \mathrm{e}-05)$ \\
\hline \multirow[t]{2}{*}{ L2.Conventional } & $1.0 \mathrm{e}-05$ & $-4.4 \mathrm{e}-05$ & $-2.2 \mathrm{e}-05$ & $-1.9 \mathrm{e}-05$ & -.00011 & -.00013 \\
\hline & $(5.5 \mathrm{e}-05)$ & $(.00011)$ & $(8.5 \mathrm{e}-05)$ & $(6.5 \mathrm{e}-05)$ & $(.00013)$ & $(9.8 \mathrm{e}-05)$ \\
\hline \multicolumn{7}{|l|}{ Energy prices (firm level): } \\
\hline \multirow[t]{2}{*}{ L1.Coal } & $-.3386^{* *}$ & $-.4291^{*}$ & -.224 & $-.4513^{* *}$ & $-.8458^{* * *}$ & -.362 \\
\hline & $(.1561)$ & $(.2434)$ & $(.2389)$ & $(.2093)$ & $(.2219)$ & $(.319)$ \\
\hline \multirow[t]{2}{*}{ L1.Electricity } & .1187 & -.1144 & .1484 & .1398 & .3474 & .3911 \\
\hline & $(.2118)$ & $(.2582)$ & $(.2408)$ & $(.2458)$ & $(.3335)$ & $(.3448)$ \\
\hline \multicolumn{7}{|c|}{ Economic controls (firm level): } \\
\hline \multirow[t]{2}{*}{ L1.GDP } & .06241 & $-.1956^{* *}$ & .03848 & $-.1808^{\dagger}$ & $-.5181^{* * *}$ & .2024 \\
\hline & $(.09833)$ & $(.0819)$ & $(.07732)$ & $(.1146)$ & $(.1201)$ & $(.1719)$ \\
\hline \multirow[t]{2}{*}{ L1.GDPcap } & $1.108^{\dagger}$ & -.2031 & .4047 & .5862 & 1.328 & $-3.006^{*}$ \\
\hline & $(.7545)$ & $(.5656)$ & $(.9149)$ & $(.9894)$ & $(.9328)$ & $(1.686)$ \\
\hline \multirow[t]{2}{*}{ L1.Popdensity } & $.1441^{* *}$ & -.01553 & .00187 & -.03815 & .2018 & -.08044 \\
\hline & $(.06363)$ & $(.1219)$ & $(.1472)$ & $(.09704)$ & $(.1774)$ & $(.2615)$ \\
\hline Pre-sample history & Yes & Yes & Yes & Yes & Yes & Yes \\
\hline Pre-sample dummy & Yes & Yes & Yes & Yes & Yes & Yes \\
\hline Firm FE & Yes & Yes & Yes & Yes & Yes & Yes \\
\hline Year trend & Yes & Yes & Yes & Yes & Yes & Yes \\
\hline Country dummy & No & No & No & Yes & Yes & Yes \\
\hline Year x Country dummy & No & No & No & No & No & No \\
\hline Number of observations & 47473 & 11281 & 11631 & 38222 & 9210 & 10035 \\
\hline
\end{tabular}

Significance levels: $\quad{ }^{* * *}: 1 \% \quad{ }^{* *}: 5 \% \quad{ }^{*}: 10 \%$

Note: The top five countries are the US, Japan, Germany, France, and Great Britain. 
Table B.12: Baseline specification using 2016 OECD patent data.

\begin{tabular}{|c|c|c|c|}
\hline & \multicolumn{3}{|c|}{ Dependent variable: firm-level patents } \\
\hline & \multicolumn{3}{|c|}{ Most innovative firms } \\
\hline & Renewable & Conventional & Storage \\
\hline \multicolumn{4}{|c|}{ Internal knowledge (marginal effects): } \\
\hline \multirow[t]{2}{*}{ L2.Storage } & $.00498^{* * *}$ & $.00222^{*}$ & $-.00284^{*}$ \\
\hline & $(.00168)$ & $(.00134)$ & $(.00159)$ \\
\hline \multirow[t]{2}{*}{ L2.Renewable } & -.00069 & $.00167^{*}$ & $.00155^{* * *}$ \\
\hline & $(.00054)$ & $(.00087)$ & $(.00046)$ \\
\hline \multirow{2}{*}{ L2.Conventional } & .00041 & $-.00349^{* * *}$ & .0039 \\
\hline & $(.00228)$ & $(.0013)$ & $(.00474)$ \\
\hline \multicolumn{4}{|l|}{ External knowledge: } \\
\hline \multirow[t]{2}{*}{ L2.Storage } & $.00036^{* * *}$ & -.00032 & .00011 \\
\hline & $(.00013)$ & $(.00029)$ & $(.00023)$ \\
\hline \multirow[t]{2}{*}{ L2.Renewable } & $-6.3 \mathrm{e}-05^{* *}$ & $2.8 \mathrm{e}-05$ & $-9.4 \mathrm{e}-06$ \\
\hline & $(2.5 \mathrm{e}-05)$ & $(5.0 \mathrm{e}-05)$ & $(4.4 \mathrm{e}-05)$ \\
\hline \multirow[t]{2}{*}{ L2.Conventional } & $-4.3 \mathrm{e}-05$ & $-.00049^{*}$ & -.00014 \\
\hline & $(.00013)$ & $(.00026)$ & $(.00023)$ \\
\hline \multicolumn{4}{|l|}{ Energy prices (firm level): } \\
\hline \multirow[t]{2}{*}{ L1.Coal } & .0786 & -.1242 & .2357 \\
\hline & $(.1124)$ & $(.2699)$ & $(.2229)$ \\
\hline \multirow[t]{2}{*}{ L1.Electricity } & .03788 & .01372 & .03303 \\
\hline & $(.1819)$ & $(.3296)$ & $(.2376)$ \\
\hline \multicolumn{4}{|c|}{ Economic controls (firm level): } \\
\hline \multirow[t]{2}{*}{ L1.GDP } & .04154 & -.02376 & .08893 \\
\hline & $(.1561)$ & $(.2393)$ & $(.1953)$ \\
\hline \multirow[t]{2}{*}{ L1.GDPcap } & $1.15^{*}$ & $-1.768^{\dagger}$ & .9131 \\
\hline & $(.6948)$ & $(1.19)$ & $(.8127)$ \\
\hline \multirow[t]{2}{*}{ L1.Popdensity } & .03557 & -.2762 & .04939 \\
\hline & $(.1601)$ & $(.2651)$ & $(.2199)$ \\
\hline Pre-sample history & Yes & Yes & Yes \\
\hline Pre-sample dummy & Yes & Yes & Yes \\
\hline Firm FE & Yes & Yes & Yes \\
\hline Year trend & Yes & Yes & Yes \\
\hline Country dummy & No & No & No \\
\hline Year x Country dummy & No & No & No \\
\hline Number of observations & 24607 & 9028 & 10308 \\
\hline
\end{tabular}

Significance levels: $\quad{ }^{* * *}: 1 \% \quad{ }^{* *}: 5 \% \quad{ }^{*}: 10 \%$ 


\section{B.vi Sample selection}

Another potential issue relates to sample selection. We deal with this by considering alternative firm sizes and a different selection of countries. Our sample totals 13,877 firms, with a large heterogeneity in the number of patents per firm. One might argue that firms with more patents behave differently from other firms, and to address this, we estimate our baseline model for a subsample containing only the top $15 \%$ most innovative firms (Table B.13). To be among the top $15 \%$, firms must have filed more than 15 patent applications over the sampling period. Together, these firms account for $78 \%$ of all patents in our sample. We consider other cutoff values for what constitutes a large firm, but because our results are robust to different cutoff levels, we present only the results for the top $15 \% .^{5}$ The estimation results for this subsample are consistent with our baseline results, suggesting that the largest firms are representative of the full sample.

Regarding the selection of countries, Figure A.1 shows the low number of firms and patents for many countries. We deal with this by estimating our model with a complete set of fixed effects for a five-country subsample. We extend the subsample to include the 12 most innovative countries (Table B.14). Our main results are robust to this modification, implying that the implications of our results extend beyond the five most innovative countries. The same is true if we consider the top 10 or 15 countries. ${ }^{6}$ Our regional analysis also extends to different regional spillovers. Our baseline estimation includes eleven regions for knowledge spillovers, based on the World Bank's income classification. We report three alternative definitions of regions that define spillovers occurring: (i) at the country level (Table B.15); (ii) within five world regions, as defined by the Fédération International de Football Association (FIFA), (Table B.16) ${ }^{7}$ and (iii) at the global level, so that all countries are subject to the same knowledge spillovers (Table B.17). Alternative definitions of spillover regions do not qualitatively change the results regarding how external knowledge in storage affects innovation in generating technologies. ${ }^{8}$

\footnotetext{
${ }^{5}$ Whereas the firms with more than 15 patents each account for $15 \%$ of firms and $78 \%$ of total patents in our sample, firms with more than 20 patents account for $11.7 \%$ of firms and $73 \%$ of patents.

${ }^{6}$ Note that we do not report the results for the top 10 and top 15 subsamples, as they are similar to the other results. However, these results are available from the authors upon request.

${ }^{7}$ The five FIFA regions are Africa, Asia and the Pacific, Europe, Latin America and the Caribbean, and North America.

${ }^{8}$ Estimating the baseline model without R\&D spillovers also yields estimates that are consistent with our baseline results.
} 
Table B.13: Baseline model including only the most innovative firms (15\% of sample).

\begin{tabular}{|c|c|c|c|c|c|c|}
\hline & \multicolumn{6}{|c|}{ Dependent variable: firm-level patents } \\
\hline & \multicolumn{3}{|c|}{ All countries } & \multicolumn{3}{|c|}{ Top five countries } \\
\hline & Renewable & Conventional & Storage & Renewable & Conventional & Storage \\
\hline \multicolumn{7}{|c|}{ Internal knowledge (marginal effects): } \\
\hline L2.Storage & $\begin{array}{c}.01078^{* * *} \\
(.00379)\end{array}$ & $\begin{array}{l}.00654^{* *} \\
(.00315)\end{array}$ & $\begin{array}{c}-.00692^{* * *} \\
(.00248)\end{array}$ & $\begin{array}{c}.01061^{* * *} \\
(.00398)\end{array}$ & $\begin{array}{l}.00745^{* *} \\
(.00338)\end{array}$ & $\begin{array}{c}-.00635^{* * *} \\
(.00232)\end{array}$ \\
\hline L2.Renewable & $\begin{array}{c}-.00149^{* *} \\
(.00068)\end{array}$ & $\begin{array}{c}.00022 \\
(.00166)\end{array}$ & $\begin{array}{l}.00201^{* * *} \\
(.00054)\end{array}$ & $\begin{array}{c}-.00137^{*} \\
(.0007)\end{array}$ & $\begin{array}{l}-9.5 \mathrm{e}-06 \\
(.00162)\end{array}$ & $\begin{array}{c}.00192^{* * *} \\
(.00057)\end{array}$ \\
\hline L2.Conventional & $\begin{array}{l}-.00356 \\
(.00244)\end{array}$ & $\begin{array}{c}.0008 \\
(.00201)\end{array}$ & $\begin{array}{l}-.00099 \\
(.00526)\end{array}$ & $\begin{array}{l}-.00375 \\
(.00256)\end{array}$ & $\begin{array}{l}.00225 \\
(.0027)\end{array}$ & $\begin{array}{l}-.00067 \\
(.00528)\end{array}$ \\
\hline \multicolumn{7}{|l|}{ External knowledge: } \\
\hline L2.Storage & $\begin{array}{c}.0003^{* *} \\
(.00014)\end{array}$ & $\begin{array}{l}-3.1 \mathrm{e}-05 \\
(.00021)\end{array}$ & $\begin{array}{l}.00033^{*} \\
(.00018)\end{array}$ & $\begin{array}{c}.0002 \\
(.00015)\end{array}$ & $\begin{array}{l}-6.3 \mathrm{e}-05 \\
(.00021)\end{array}$ & $\begin{array}{l}-3.2 \mathrm{e}-05 \\
(.00018)\end{array}$ \\
\hline L2.Renewable & $\begin{array}{c}-7.5 \mathrm{e}-05^{* * *} \\
(2.5 \mathrm{e}-05)\end{array}$ & $\begin{array}{l}-2.0 \mathrm{e}-05 \\
(5.1 \mathrm{e}-05)\end{array}$ & $\begin{array}{c}-7.8 \mathrm{e}-05^{*} \\
(4.2 \mathrm{e}-05)\end{array}$ & $\begin{array}{c}-7.0 \mathrm{e}-05^{* * *} \\
(2.7 \mathrm{e}-05)\end{array}$ & $\begin{array}{l}-1.4 \mathrm{e}-05 \\
(4.7 \mathrm{e}-05)\end{array}$ & $\begin{array}{c}-5.5 \mathrm{e}-06 \\
(4.6 \mathrm{e}-05)\end{array}$ \\
\hline L2.Conventional & $\begin{array}{c}-1.6 \mathrm{e}-05 \\
(5.9 \mathrm{e}-05)\end{array}$ & $\begin{array}{l}-8.6 \mathrm{e}-05 \\
(.00011)\end{array}$ & $\begin{array}{c}-2.7 \mathrm{e}-05 \\
(.0001)\end{array}$ & $\begin{array}{l}-5.5 \mathrm{e}-05 \\
(6.7 \mathrm{e}-05)\end{array}$ & $\begin{array}{l}-3.2 \mathrm{e}-05 \\
(.00013)\end{array}$ & $\begin{array}{l}-.00014 \\
(.00011)\end{array}$ \\
\hline \multicolumn{7}{|l|}{ Energy prices (firm level): } \\
\hline L1.Coal & $\begin{array}{c}-.4048^{* *} \\
(.1812)\end{array}$ & $\begin{array}{c}-.6007^{* *} \\
(.2462)\end{array}$ & $\begin{array}{l}-.1876 \\
(.2594)\end{array}$ & $\begin{array}{c}-.5167^{* *} \\
(.2403)\end{array}$ & $\begin{array}{c}-.7765^{* * *} \\
(.2316)\end{array}$ & $\begin{array}{c}-.338 \\
(.3554)\end{array}$ \\
\hline L1.Electricity & $\begin{array}{l}.09295 \\
(.2313)\end{array}$ & $\begin{array}{l}-.1269 \\
(.2916)\end{array}$ & $\begin{array}{c}.1187 \\
(.3056)\end{array}$ & $\begin{array}{c}.1335 \\
(.2597)\end{array}$ & $\begin{array}{c}.1764 \\
(.3695)\end{array}$ & $\begin{array}{l}.4321 \\
(.3941)\end{array}$ \\
\hline \multicolumn{7}{|c|}{ Economic controls (firm level): } \\
\hline L1.GDP & $\begin{array}{c}-.165^{*} \\
(.08979)\end{array}$ & $\begin{array}{c}-.3201^{* * *} \\
(.09227)\end{array}$ & $\begin{array}{c}.257 \\
(.1938)\end{array}$ & $\begin{array}{l}-.2291^{* *} \\
(.09702)\end{array}$ & $\begin{array}{l}-.318^{* *} \\
(.1293)\end{array}$ & $\begin{array}{r}-.00017 \\
(.3161)\end{array}$ \\
\hline L1.GDPcap & $\begin{array}{l}1.759^{* *} \\
(.7639)\end{array}$ & $\begin{array}{c}.8876 \\
(.6829)\end{array}$ & $\begin{array}{c}.4023 \\
(1.266)\end{array}$ & $\begin{array}{c}.8371 \\
(.8351)\end{array}$ & $\begin{array}{c}1.651 \\
(1.201)\end{array}$ & $\begin{array}{l}-2.642 \\
(1.756)\end{array}$ \\
\hline L1.Popdensity & $\begin{array}{c}.1825^{* *} \\
(.07741) \\
\end{array}$ & $\begin{array}{r}-.01429 \\
(.1436) \\
\end{array}$ & $\begin{array}{l}-.2004 \\
(.2263) \\
\end{array}$ & $\begin{array}{c}.1461 \\
(.1053) \\
\end{array}$ & $\begin{array}{c}.2102 \\
(.1762) \\
\end{array}$ & $\begin{array}{c}-.7463^{* *} \\
(.303)\end{array}$ \\
\hline Pre-sample history & Yes & Yes & Yes & Yes & Yes & Yes \\
\hline Pre-sample dummy & Yes & Yes & Yes & Yes & Yes & Yes \\
\hline Firm FE & Yes & Yes & Yes & Yes & Yes & Yes \\
\hline Year dummy & Yes & Yes & Yes & Yes & Yes & Yes \\
\hline Country dummy & No & No & No & Yes & Yes & Yes \\
\hline Year x Country dummy & No & No & No & No & No & No \\
\hline Number of observations & 17218 & 6841 & 7332 & 14806 & 5728 & 6500 \\
\hline
\end{tabular}

Significance levels: ${ }^{* * *}: 1 \% \quad{ }^{* *}: 5 \% \quad{ }^{*}: 10 \%$

Note: The top five countries are the US, Japan, Germany, France, and Great Britain. 
Table B.14: Sub-sample of the twelve most innovative countries.

\begin{tabular}{|c|c|c|c|c|c|c|}
\hline & \multicolumn{6}{|c|}{ Dependent variable: firm-level patents } \\
\hline & \multicolumn{3}{|c|}{ All countries } & \multicolumn{3}{|c|}{ Top twelve countries } \\
\hline & Renewable & Conventional & Storage & Renewable & Conventional & Storage \\
\hline \multicolumn{7}{|c|}{ Internal knowledge (marginal effects): } \\
\hline L2.Storage & $\begin{array}{c}.01124^{* * *} \\
(.0038)\end{array}$ & $\begin{array}{l}.00662^{* *} \\
(.00312)\end{array}$ & $\begin{array}{c}-.00728^{* *} \\
(.00291)\end{array}$ & $\begin{array}{l}.01115^{* * *} \\
(.00381)\end{array}$ & $\begin{array}{l}.00725^{* *} \\
(.00313)\end{array}$ & $\begin{array}{c}-.00709^{* *} \\
(.00288)\end{array}$ \\
\hline L2.Renewable & $\begin{array}{c}-.00191^{* *} \\
(.00076)\end{array}$ & $\begin{array}{l}-.00019 \\
(.00174)\end{array}$ & $\begin{array}{c}.00182^{* * *} \\
(.00052)\end{array}$ & $\begin{array}{l}-.00183^{* *} \\
(.00076)\end{array}$ & $\begin{array}{c}-.0003 \\
(.00161)\end{array}$ & $\begin{array}{l}.00181^{* * * *} \\
(.00053)\end{array}$ \\
\hline L2.Conventional & $\begin{array}{l}-.00372 \\
(.00254)\end{array}$ & $\begin{array}{l}.00039 \\
(.00216)\end{array}$ & $\begin{array}{l}-.00046 \\
(.00565)\end{array}$ & $\begin{array}{l}-.00381 \\
(.00257)\end{array}$ & $\begin{array}{l}.00085 \\
(.00208)\end{array}$ & $\begin{array}{l}-.00038 \\
(.00569)\end{array}$ \\
\hline \multicolumn{7}{|l|}{ External knowledge: } \\
\hline L2.Storage & $\begin{array}{l}.00024^{*} \\
(.00013)\end{array}$ & $\begin{array}{c}-7.1 \mathrm{e}-05 \\
(.0002)\end{array}$ & $\begin{array}{l}.00024 \\
(.00016)\end{array}$ & $\begin{array}{l}.00023^{*} \\
(.00014)\end{array}$ & $\begin{array}{c}-8.7 \mathrm{e}-05 \\
(.0002)\end{array}$ & $\begin{array}{c}.00024 \\
(.00016)\end{array}$ \\
\hline L2.Renewable & $\begin{array}{c}-7.2 \mathrm{e}-05^{* * *} \\
(2.3 \mathrm{e}-05)\end{array}$ & $\begin{array}{l}-2.2 \mathrm{e}-05 \\
(4.8 \mathrm{e}-05)\end{array}$ & $\begin{array}{l}-6.8 \mathrm{e}-05^{*} \\
(3.5 \mathrm{e}-05)\end{array}$ & $\begin{array}{c}-7.0 \mathrm{e}-05^{* * *} \\
(2.4 \mathrm{e}-05)\end{array}$ & $\begin{array}{c}3.5 \mathrm{e}-06 \\
(4.6 \mathrm{e}-05)\end{array}$ & $\begin{array}{l}-6.2 \mathrm{e}-05 \\
(3.9 \mathrm{e}-05)\end{array}$ \\
\hline L2.Conventional & $\begin{array}{l}-3.0 \mathrm{e}-05 \\
(5.4 \mathrm{e}-05)\end{array}$ & $\begin{array}{c}-7.8 \mathrm{e}-05 \\
(.0001)\end{array}$ & $\begin{array}{l}-6.2 \mathrm{e}-08 \\
(9.1 \mathrm{e}-05)\end{array}$ & $\begin{array}{l}-3.5 \mathrm{e}-05 \\
(5.8 \mathrm{e}-05)\end{array}$ & $\begin{array}{c}-2.6 \mathrm{e}-05 \\
(.0001)\end{array}$ & $\begin{array}{c}1.3 \mathrm{e}-05 \\
(9.2 \mathrm{e}-05)\end{array}$ \\
\hline \multicolumn{7}{|l|}{ Energy prices (firm level): } \\
\hline L1.Coal & $\begin{array}{c}-.3936^{* *} \\
(.1533)\end{array}$ & $\begin{array}{c}-.6743^{* * *} \\
(.2311)\end{array}$ & $\begin{array}{l}-.1503 \\
(.2359)\end{array}$ & $\begin{array}{c}-.3541^{* *} \\
(.1615)\end{array}$ & $\begin{array}{c}-.8686^{* * *} \\
(.2267)\end{array}$ & $\begin{array}{l}-.1754 \\
(.2445)\end{array}$ \\
\hline L1.Electricity & $\begin{array}{l}.1167 \\
(.2076)\end{array}$ & $\begin{array}{l}-.08857 \\
(.2745)\end{array}$ & $\begin{array}{l}.126 \\
(.264)\end{array}$ & $\begin{array}{l}.06589 \\
(.2177)\end{array}$ & $\begin{array}{l}.1979 \\
(.2682)\end{array}$ & $\begin{array}{l}.1081 \\
(.2746)\end{array}$ \\
\hline \multicolumn{7}{|c|}{ Economic controls (firm level): } \\
\hline L1.GDP & $\begin{array}{c}-.1314 \\
(.08044)\end{array}$ & $\begin{array}{c}-.3213^{* * *} \\
(.08239)\end{array}$ & $\begin{array}{l}.2893 \\
(.1919)\end{array}$ & $\begin{array}{l}-.1865^{* *} \\
(.08114)\end{array}$ & $\begin{array}{c}-.2969^{* * *} \\
(.07217)\end{array}$ & $\begin{array}{l}.2252 \\
(.31)\end{array}$ \\
\hline L1.GDPcap & $\begin{array}{l}1.589^{* *} \\
(.7003)\end{array}$ & $\begin{array}{l}.7646 \\
(.6145)\end{array}$ & $\begin{array}{c}.516 \\
(1.078)\end{array}$ & $\begin{array}{l}1.513^{*} \\
(.7819)\end{array}$ & $\begin{array}{l}.8681^{*} \\
(.5272)\end{array}$ & $\begin{array}{c}.5991 \\
(1.241)\end{array}$ \\
\hline L1.Popdensity & $\begin{array}{l}.1835^{* * *} \\
(.0694)\end{array}$ & $\begin{array}{l}.00386 \\
(.1435)\end{array}$ & $\begin{array}{l}-.1699 \\
(.2061)\end{array}$ & $\begin{array}{l}.1578^{* *} \\
(.0665)\end{array}$ & $\begin{array}{c}.1221 \\
(.1199)\end{array}$ & $\begin{array}{l}-.1494 \\
(.3067)\end{array}$ \\
\hline Pre-sample history & Yes & Yes & Yes & Yes & Yes & Yes \\
\hline Pre-sample dummy & Yes & Yes & Yes & Yes & Yes & Yes \\
\hline Firm FE & Yes & Yes & Yes & Yes & Yes & Yes \\
\hline Year dummy & Yes & Yes & Yes & Yes & Yes & Yes \\
\hline Country dummy & No & No & No & Yes & Yes & Yes \\
\hline Year x Country dummy & No & No & No & No & No & No \\
\hline Number of observations & 50694 & 12881 & 11959 & 47478 & 12113 & 11549 \\
\hline
\end{tabular}

Significance levels: $\quad{ }^{* * *}: 1 \% \quad{ }^{* *}: 5 \% \quad *: 10 \%$

Note: The top twelve countries are the US, Japan, Germany, France, Great Britain, Canada, Switzerland, South Korea, Sweden, Netherlands, Finland, and Italy. 
Table B.15: Alternative specification of regional spillovers: Countries.

\begin{tabular}{|c|c|c|c|c|c|c|}
\hline & \multicolumn{6}{|c|}{ Dependent variable: firm-level patents } \\
\hline & \multicolumn{3}{|c|}{ All countries } & \multicolumn{3}{|c|}{ Top five countries } \\
\hline & Renewable & Conventional & Storage & Renewable & Conventional & Storage \\
\hline \multicolumn{7}{|c|}{ Internal knowledge (marginal effects): } \\
\hline \multirow[t]{2}{*}{ L2.Storage } & $.01163^{* * *}$ & $.00759^{* *}$ & $-.00713^{* *}$ & $.01128^{* * *}$ & $.008^{* *}$ & $-.00653^{* *}$ \\
\hline & $(.00383)$ & $(.00315)$ & $(.00286)$ & $(.004)$ & $(.0033)$ & $(.00264)$ \\
\hline \multirow[t]{2}{*}{ L2.Renewable } & $-.00186^{* *}$ & -.00026 & $.00194^{* * *}$ & $-.00165^{* *}$ & -.00043 & $.00177^{* * *}$ \\
\hline & $(.00078)$ & $(.00166)$ & $(.00052)$ & $(.00079)$ & $(.00168)$ & $(.00056)$ \\
\hline \multirow[t]{2}{*}{ L2.Conventional } & -.00391 & .00051 & -.00012 & -.0041 & .00212 & .00012 \\
\hline & $(.00255)$ & $(.0021)$ & $(.00567)$ & $(.00267)$ & $(.00272)$ & $(.00559)$ \\
\hline \multicolumn{7}{|l|}{ External knowledge: } \\
\hline \multirow[t]{2}{*}{ L2.Storage } & .00018 & $-3.3 \mathrm{e}-05$ & .00018 & $6.8 \mathrm{e}-05$ & $3.6 \mathrm{e}-05$ & $-3.7 \mathrm{e}-05$ \\
\hline & $(.00015)$ & $(.00024)$ & $(.00021)$ & $(.00016)$ & $(.00024)$ & $(.00021)$ \\
\hline \multirow[t]{2}{*}{ L2.Renewable } & $-2.2 \mathrm{e}-05$ & $-1.8 \mathrm{e}-05$ & $-5.7 \mathrm{e}-05$ & $9.7 \mathrm{e}-06$ & $-3.7 \mathrm{e}-05$ & $1.9 \mathrm{e}-06$ \\
\hline & $(2.3 \mathrm{e}-05)$ & $(4.1 \mathrm{e}-05)$ & $(4.2 \mathrm{e}-05)$ & $(2.3 \mathrm{e}-05)$ & $(4.8 \mathrm{e}-05)$ & $(4.4 \mathrm{e}-05)$ \\
\hline \multirow[t]{2}{*}{ L2.Conventional } & $-.00014^{*}$ & .00011 & $8.2 \mathrm{e}-05$ & $-.00024^{* * *}$ & .00018 & $1.7 \mathrm{e}-06$ \\
\hline & $(7.9 \mathrm{e}-05)$ & $(.00011)$ & $(.00014)$ & $(8.1 \mathrm{e}-05)$ & $(.00015)$ & $(.00015)$ \\
\hline \multicolumn{7}{|l|}{ Energy prices (firm level): } \\
\hline \multirow[t]{2}{*}{ L1.Coal } & $-.4206^{* * *}$ & $-.6762^{* * *}$ & -.08994 & $-.5757^{* * *}$ & $-.8846^{* * *}$ & -.222 \\
\hline & $(.1537)$ & $(.249)$ & $(.2491)$ & $(.2059)$ & $(.2421)$ & $(.3317)$ \\
\hline \multirow[t]{2}{*}{ L1.Electricity } & .1732 & -.06774 & .01877 & .3266 & .2298 & .4495 \\
\hline & $(.2017)$ & $(.28)$ & $(.2739)$ & $(.2302)$ & $(.369)$ & $(.3562)$ \\
\hline \multicolumn{7}{|c|}{ Economic controls (firm level): } \\
\hline \multirow[t]{2}{*}{ L1.GDP } & -.1268 & $-.3259^{* * *}$ & $.3312^{*}$ & $-.2011^{* *}$ & $-.3717^{* * *}$ & -.02369 \\
\hline & $(.08196)$ & $(.08301)$ & $(.1822)$ & $(.0859)$ & $(.1093)$ & $(.2626)$ \\
\hline \multirow[t]{2}{*}{ L1.GDPcap } & $1.479^{* *}$ & .7437 & -.2117 & .6715 & $1.919^{*}$ & -2.368 \\
\hline & $(.6949)$ & $(.6171)$ & $(1.017)$ & $(.8251)$ & $(1.014)$ & $(1.579)$ \\
\hline \multirow[t]{2}{*}{ L1.Popdensity } & $.1456^{* *}$ & .00437 & -.19 & .1147 & .2566 & $-.7865^{* * *}$ \\
\hline & $(.06425)$ & $(.1462)$ & $(.2044)$ & $(.09073)$ & $(.1605)$ & $(.3049)$ \\
\hline Pre-sample history & Yes & Yes & Yes & Yes & Yes & Yes \\
\hline Pre-sample dummy & Yes & Yes & Yes & Yes & Yes & Yes \\
\hline Firm FE & Yes & Yes & Yes & Yes & Yes & Yes \\
\hline Year dummy & Yes & Yes & Yes & Yes & Yes & Yes \\
\hline Country dummy & No & No & No & Yes & Yes & Yes \\
\hline Year x Country dummy & No & No & No & No & No & No \\
\hline Number of observations & 50694 & 12881 & 11959 & 40969 & 10487 & 10341 \\
\hline
\end{tabular}

Significance levels: $\quad{ }^{* * *}: 1 \% \quad{ }^{* *}: 5 \% \quad{ }^{*}: 10 \%$

Note: The top five countries are the US, Japan, Germany, France, and Great Britain. 
Table B.16: Alternative specification of regional spillovers: FIFA regions.

\begin{tabular}{|c|c|c|c|c|c|c|}
\hline & \multicolumn{6}{|c|}{ Dependent variable: firm-level patents } \\
\hline & \multicolumn{3}{|c|}{ All countries } & \multicolumn{3}{|c|}{ Top five countries } \\
\hline & Renewable & Conventional & Storage & Renewable & Conventional & Storage \\
\hline \multicolumn{7}{|c|}{ Internal knowledge (marginal effects): } \\
\hline \multirow[t]{2}{*}{ L2.Storage } & $.01117^{* * *}$ & $.0071^{* *}$ & $-.00725^{* *}$ & $.01112^{* * *}$ & $.00767^{* *}$ & $-.00657^{* *}$ \\
\hline & $(.00379)$ & $(.0031)$ & $(.0029)$ & $(.00401)$ & $(.00333)$ & $(.00264)$ \\
\hline \multirow[t]{2}{*}{ L2.Renewable } & $-.00193^{* *}$ & -.00027 & $.00181^{* * *}$ & $-.00172^{* *}$ & -.00033 & $.00176^{* * *}$ \\
\hline & $(.00076)$ & $(.00169)$ & $(.00053)$ & $(.00077)$ & $(.0017)$ & $(.00056)$ \\
\hline \multirow[t]{2}{*}{ L2.Conventional } & -.00377 & .00043 & -.00044 & -.00385 & .00203 & -.00017 \\
\hline & $(.00254)$ & $(.00214)$ & $(.00567)$ & $(.00265)$ & $(.00285)$ & $(.00562)$ \\
\hline \multicolumn{7}{|l|}{ External knowledge: } \\
\hline \multirow[t]{2}{*}{ L2.Storage } & $.00027^{* *}$ & $-5.7 \mathrm{e}-05$ & $.00029^{*}$ & .00017 & -.00012 & $-6.3 e-05$ \\
\hline & $(.00014)$ & $(.0002)$ & $(.00017)$ & $(.00015)$ & $(.00021)$ & $(.00018)$ \\
\hline \multirow[t]{2}{*}{ L2.Renewable } & $-8.3 \mathrm{e}-05^{* * *}$ & $-9.9 \mathrm{e}-06$ & $-7.9 \mathrm{e}-05^{*}$ & $-6.9 \mathrm{e}-05^{* *}$ & $-1.6 \mathrm{e}-05$ & $-4.4 \mathrm{e}-06$ \\
\hline & $(2.5 \mathrm{e}-05)$ & $(4.9 \mathrm{e}-05)$ & $(4.1 \mathrm{e}-05)$ & $(2.7 \mathrm{e}-05)$ & $(4.8 \mathrm{e}-05)$ & $(4.5 \mathrm{e}-05)$ \\
\hline \multirow[t]{2}{*}{ L2.Conventional } & $-3.4 \mathrm{e}-05$ & $-8.5 \mathrm{e}-06$ & $1.5 \mathrm{e}-05$ & $-6.1 \mathrm{e}-05$ & $-1.7 \mathrm{e}-05$ & $-9.1 \mathrm{e}-05$ \\
\hline & $(5.6 \mathrm{e}-05)$ & $(.0001)$ & $(9.0 \mathrm{e}-05)$ & $(6.2 \mathrm{e}-05)$ & $(.00012)$ & $(9.6 \mathrm{e}-05)$ \\
\hline \multicolumn{7}{|l|}{ Energy prices (firm level): } \\
\hline \multirow[t]{2}{*}{ L1.Coal } & $-.3907^{* *}$ & $-.668^{* * *}$ & -.1492 & $-.5027^{* *}$ & $-.8457^{* * *}$ & -.272 \\
\hline & $(.1518)$ & $(.2365)$ & $(.2349)$ & $(.2074)$ & $(.2157)$ & $(.3209)$ \\
\hline \multirow[t]{2}{*}{ L1.Electricity } & .09573 & -.08409 & .1212 & .1373 & .174 & .386 \\
\hline & $(.2076)$ & $(.2792)$ & $(.2671)$ & $(.2409)$ & $(.3401)$ & $(.3561)$ \\
\hline \multicolumn{7}{|c|}{ Economic controls (firm level): } \\
\hline \multirow[t]{2}{*}{ L1.GDP } & $-.1496^{*}$ & $-.3284^{* * *}$ & .2882 & $-.2185^{* *}$ & $-.3606^{* * *}$ & .00258 \\
\hline & $(.08279)$ & $(.08349)$ & $(.1899)$ & $(.08995)$ & $(.1124)$ & $(.2945)$ \\
\hline \multirow[t]{2}{*}{ L1.GDPcap } & $1.62^{* *}$ & .7944 & .564 & .714 & $1.802^{*}$ & -2.235 \\
\hline & $(.7051)$ & $(.6245)$ & $(1.079)$ & $(.8121)$ & $(1.074)$ & $(1.607)$ \\
\hline \multirow[t]{2}{*}{ L1.Popdensity } & $.175^{* * *}$ & .00278 & -.1666 & .1274 & .2476 & $-.7141^{* *}$ \\
\hline & $(.06759)$ & $(.1466)$ & $(.2073)$ & $(.09788)$ & $(.1686)$ & $(.2956)$ \\
\hline Pre-sample history & Yes & Yes & Yes & Yes & Yes & Yes \\
\hline Pre-sample dummy & Yes & Yes & Yes & Yes & Yes & Yes \\
\hline Firm FE & Yes & Yes & Yes & Yes & Yes & Yes \\
\hline Year dummy & Yes & Yes & Yes & Yes & Yes & Yes \\
\hline Country dummy & No & No & No & Yes & Yes & Yes \\
\hline Year x Country dummy & No & No & No & No & No & No \\
\hline Number of observations & 50694 & 12881 & 11959 & 40969 & 10487 & 10341 \\
\hline
\end{tabular}

Significance levels: $\quad{ }^{* * *}: 1 \% \quad{ }^{* *}: 5 \% \quad{ }^{*}: 10 \%$

Note: The top five countries are the US, Japan, Germany, France, and Great Britain. 
Table B.17: Alternative specification of regional spillovers: Global.

\begin{tabular}{|c|c|c|c|c|c|c|}
\hline & \multicolumn{6}{|c|}{ Dependent variable: firm-level patents } \\
\hline & \multicolumn{3}{|c|}{ All countries } & \multicolumn{3}{|c|}{ Top five countries } \\
\hline & Renewable & Conventional & Storage & Renewable & Conventional & Storage \\
\hline \multicolumn{7}{|c|}{ Internal knowledge (marginal effects): } \\
\hline \multirow[t]{2}{*}{ L2.Storage } & $.01119^{* * *}$ & $.00656^{* *}$ & $-.01053^{* * *}$ & $.01238^{* * *}$ & $.00677^{*}$ & $-.01015^{* * *}$ \\
\hline & $(.00346)$ & $(.00327)$ & $(.00275)$ & $(.00396)$ & $(.00372)$ & $(.00259)$ \\
\hline \multirow[t]{2}{*}{ L2.Renewable } & $-.00178^{* *}$ & -.00101 & $.00437^{* *}$ & $-.00171^{* *}$ & .00089 & $.00395^{*}$ \\
\hline & $(.00081)$ & $(.00251)$ & $(.00177)$ & $(.00083)$ & $(.00266)$ & $(.00203)$ \\
\hline \multirow[t]{2}{*}{ L2.Conventional } & -.00303 & .00951 & -.02851 & -.00305 & -.01758 & -.02446 \\
\hline & $(.00259)$ & $(.03308)$ & $(.02345)$ & $(.00274)$ & $(.03838)$ & $(.02717)$ \\
\hline \multicolumn{7}{|l|}{ External knowledge: } \\
\hline \multirow[t]{2}{*}{ L2.Storage } & .00039 & -.00038 & $-.0032^{* * *}$ & .00042 & -.00068 & $-.00363^{* * *}$ \\
\hline & $(.00033)$ & $(.00166)$ & $(.00095)$ & $(.00037)$ & $(.00206)$ & $(.00104)$ \\
\hline \multirow[t]{2}{*}{ L2.Renewable } & $-7.4 \mathrm{e}-05^{* *}$ & -.00059 & .0024 & $-8.0 \mathrm{e}-05^{* *}$ & .0014 & .0022 \\
\hline & $(2.9 \mathrm{e}-05)$ & $(.0024)$ & $(.00162)$ & $(3.2 \mathrm{e}-05)$ & $(.00284)$ & $(.00186)$ \\
\hline \multirow[t]{2}{*}{ L2.Conventional } & $.00033^{* * *}$ & .0091 & -.02856 & $.00035^{* * *}$ & -.01945 & -.02457 \\
\hline & $(5.5 \mathrm{e}-05)$ & $(.03269)$ & $(.02299)$ & $(6.8 \mathrm{e}-05)$ & $(.03766)$ & $(.02649)$ \\
\hline \multicolumn{7}{|l|}{ Energy prices (firm level): } \\
\hline \multirow[t]{2}{*}{ L1.Coal } & -.00017 & $-.6603^{* * *}$ & -.1427 & -.00055 & $-.9064^{* * *}$ & -.2472 \\
\hline & $(.1631)$ & $(.2304)$ & $(.251)$ & $(.2175)$ & $(.2326)$ & $(.3299)$ \\
\hline \multirow[t]{2}{*}{ L1.Electricity } & $2.6 \mathrm{e}-05$ & -.05319 & .1077 & $6.3 \mathrm{e}-05$ & .2618 & .4747 \\
\hline & $(.2004)$ & $(.2775)$ & $(.2585)$ & $(.2379)$ & $(.3631)$ & $(.3362)$ \\
\hline \multicolumn{7}{|c|}{ Economic controls (firm level): } \\
\hline \multirow[t]{2}{*}{ L1.GDP } & $-3.0 \mathrm{e}-05$ & $-.329^{* * *}$ & .2375 & -.00023 & $-.3608^{* * *}$ & -.03147 \\
\hline & $(.09146)$ & $(.07766)$ & $(.2003)$ & $(.1267)$ & $(.1103)$ & $(.2732)$ \\
\hline \multirow[t]{2}{*}{ L1.GDPcap } & $1.6 \mathrm{e}-05$ & .8382 & .1055 & $-1.1 \mathrm{e}-05$ & 1.881 & -2.235 \\
\hline & $(.7463)$ & $(.6559)$ & $(1.106)$ & $(.9717)$ & $(1.165)$ & $(1.503)$ \\
\hline \multirow[t]{2}{*}{ L1.Popdensity } & $1.4 \mathrm{e}-05$ & .00553 & -.2333 & $9.2 \mathrm{e}-05$ & .258 & $-.769^{* * *}$ \\
\hline & $(.07034)$ & $(.1422)$ & $(.2283)$ & $(.1118)$ & $(.1648)$ & $(.2984)$ \\
\hline Pre-sample history & Yes & Yes & Yes & Yes & Yes & Yes \\
\hline Pre-sample dummy & Yes & Yes & Yes & Yes & Yes & Yes \\
\hline Firm FE & Yes & Yes & Yes & Yes & Yes & Yes \\
\hline Year dummy & Yes & Yes & Yes & Yes & Yes & Yes \\
\hline Country dummy & No & No & No & Yes & Yes & Yes \\
\hline Year x Country dummy & No & No & No & No & No & No \\
\hline Number of observations & 50694 & 12881 & 11959 & 40969 & 10487 & 10341 \\
\hline
\end{tabular}

Significance levels: $\quad{ }^{* * *}: 1 \% \quad{ }^{* *}: 5 \% \quad{ }^{*}: 10 \%$

Note: The top five countries are the US, Japan, Germany, France, and Great Britain. 


\section{B.vii Citation data}

Table B.18: Baseline model with citation-adjusted knowledge stocks.

\begin{tabular}{|c|c|c|c|c|c|c|}
\hline & \multicolumn{6}{|c|}{ Dependent variable: firm-level patents } \\
\hline & \multicolumn{3}{|c|}{ All countries } & \multicolumn{3}{|c|}{ Top five countries } \\
\hline & Renewable & Conventional & Storage & Renewable & Conventional & Storage \\
\hline \multicolumn{7}{|c|}{ Internal knowledge (marginal effects): } \\
\hline \multirow[t]{2}{*}{ L2.Storage } & $.00079^{* * *}$ & $.00133^{*}$ & $-.00045^{* *}$ & $.00087^{* * *}$ & $.00091^{*}$ & $-.00039^{* *}$ \\
\hline & $(.00016)$ & $(.0008)$ & $(.00021)$ & $(.00017)$ & $-.00039^{* *}$ & $(.0002)$ \\
\hline \multirow[t]{2}{*}{ L2.Renewable } & $-.00023^{* * *}$ & $-1.2 \mathrm{e}-05$ & $8.0 \mathrm{e}-05$ & $-.00022^{* * *}$ & .00014 & $7.6 \mathrm{e}-05$ \\
\hline & $(3.6 \mathrm{e}-05)$ & $(.00013)$ & $(7.0 \mathrm{e}-05)$ & $(4.0 \mathrm{e}-05)$ & $(.00011)$ & $(7.2 \mathrm{e}-05)$ \\
\hline \multirow[t]{2}{*}{ L2.Conventional } & $-1.8 \mathrm{e}-06$ & -.0002 & $.00071^{* *}$ & $4.4 \mathrm{e}-05$ & $-.00073^{* *}$ & $.00077^{* *}$ \\
\hline & $(.00031)$ & $(.00043)$ & $(.00035)$ & $(.00032)$ & $(.00028)$ & $(.00039)$ \\
\hline \multicolumn{7}{|l|}{ External knowledge: } \\
\hline \multirow[t]{2}{*}{ L2.Storage } & $.00039^{* *}$ & .00018 & .00028 & .00029 & -.00018 & $7.9 \mathrm{e}-06$ \\
\hline & $(.00019)$ & $(.0003)$ & $(.00023)$ & $(.0002)$ & $(.00034)$ & $(.00021)$ \\
\hline \multirow[t]{2}{*}{ L2.Renewable } & $-8.4 \mathrm{e}-05^{* * *}$ & $-1.8 \mathrm{e}-05$ & $-5.5 \mathrm{e}-05^{\dagger}$ & $-7.2 \mathrm{e}-05^{* *}$ & $3.6 \mathrm{e}-05$ & $-5.0 \mathrm{e}-06$ \\
\hline & $(3.1 \mathrm{e}-05)$ & $(5.0 \mathrm{e}-05)$ & $(3.7 \mathrm{e}-05)$ & $(3.2 \mathrm{e}-05)$ & $(5.7 \mathrm{e}-05)$ & $(3.7 \mathrm{e}-05)$ \\
\hline \multirow[t]{2}{*}{ L2.Conventional } & $2.5 \mathrm{e}-05$ & -.00014 & $-7.3 \mathrm{e}-05$ & $3.0 \mathrm{e}-05$ & -.0003 & -.00017 \\
\hline & $(9.1 \mathrm{e}-05)$ & $(.00018)$ & $(.00015)$ & $(.00011)$ & $(.00025)$ & $(.00016)$ \\
\hline \multicolumn{7}{|l|}{ Energy prices (firm level): } \\
\hline \multirow[t]{2}{*}{ L1.Coal } & $-.3818^{* *}$ & $-.7252^{* * *}$ & -.2489 & $-.3781^{*}$ & $-.757^{* * *}$ & -.4722 \\
\hline & $(.1696)$ & $(.1984)$ & $(.2621)$ & $(.2065)$ & $(.2352)$ & $(.3587)$ \\
\hline \multirow[t]{2}{*}{ L1.Electricity } & .1871 & -.02195 & .2302 & .248 & .3536 & .4098 \\
\hline & $(.2049)$ & $(.2922)$ & $(.2701)$ & $(.2497)$ & $(.3099)$ & $(.3614)$ \\
\hline \multicolumn{7}{|c|}{ Economic controls (firm level): } \\
\hline \multirow[t]{2}{*}{ L1.GDP } & .03231 & $-.2111^{* *}$ & -.01451 & -.1437 & $-.4452^{* * *}$ & .02241 \\
\hline & $(.09425)$ & $(.0934)$ & $(.09955)$ & $(.1146)$ & $(.1009)$ & $(.09661)$ \\
\hline \multirow[t]{2}{*}{ L1.GDPcap } & $1.607^{* *}$ & .6329 & .4792 & 1.225 & .4605 & -1.038 \\
\hline & $(.7112)$ & $(.7085)$ & $(.9403)$ & $(.9074)$ & $(.7147)$ & $(.797)$ \\
\hline \multirow[t]{2}{*}{ L1.Popdensity } & $.1272^{\dagger}$ & -.03416 & -.05764 & .08793 & .04082 & .0763 \\
\hline & $(.0783)$ & $(.1043)$ & $(.1563)$ & $(.1256)$ & $(.09491)$ & $(.277)$ \\
\hline Pre-sample history & Yes & Yes & Yes & Yes & Yes & Yes \\
\hline Pre-sample dummy & Yes & Yes & Yes & Yes & Yes & Yes \\
\hline Firm FE & Yes & Yes & Yes & Yes & Yes & Yes \\
\hline Year trend & Yes & Yes & Yes & Yes & Yes & Yes \\
\hline Country dummy & No & No & No & Yes & Yes & Yes \\
\hline Year x Country dummy & No & No & No & No & No & No \\
\hline Number of observations & 40149 & 9737 & 9896 & 32192 & 7937 & 8505 \\
\hline
\end{tabular}

Significance levels: $\quad{ }^{* * *}: 1 \% \quad{ }^{* *}: 5 \% \quad{ }^{*}: 10 \%$

Note: The top five countries are the US, Japan, Germany, France, and Great Britain. 


\section{B.viii Storage capacity}

Installed capacity does not have a statistically significant impact. We offer two explanations for this. First, while pumped hydro constitutes the majority of global storage capacity, recent storage innovation focuses on other technologies. Figure 1(a) shows global total storage capacity and the share of pumped hydro. Since mid 1990s, new installed capacity in pumped hydro has been modest while installed capacity from other technologies has increased exponentially. Figure 1(b) breaks down global total storage capacity into other storage technologies and shows that since the 1980s, new installed capacity primarily comes from electro-mechanical storage until the mid-2000 when thermal storage takes over as the dominant technology. Note, however, that as of 2016 this new installed capacity only accounts for $60 \mathrm{GW}$ of electricity storage capacity at the global level.

This brings us to the second explanation; there seems to be a long lag from innovation to deployment of new technologies. Looking at global electricity storage capacity, pumped hydro dominates until the late 1990s (cf. Figure 1(a)). However, as illustrated by Figure B.1, which shows global patenting over time, innovation in storage started to pick up already in the early 1980s. Hence, there seems to be a significant lag between the time innovators apply for patents and the time when the new technologies materialize in new storage facilities.

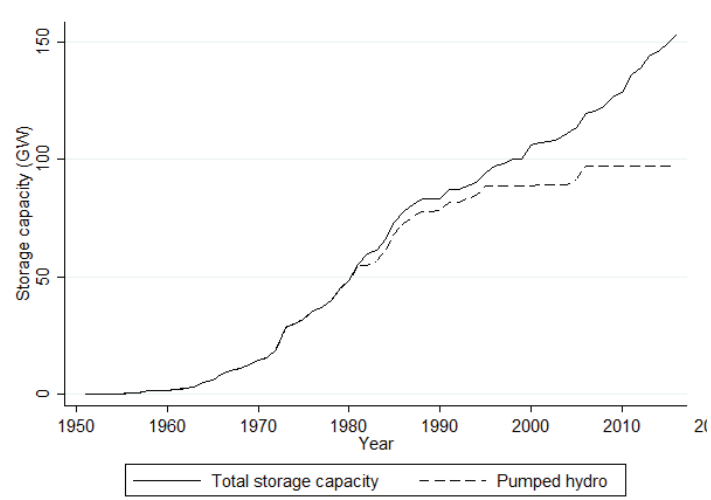

(a) Global total storage capacity and pumped hydro.

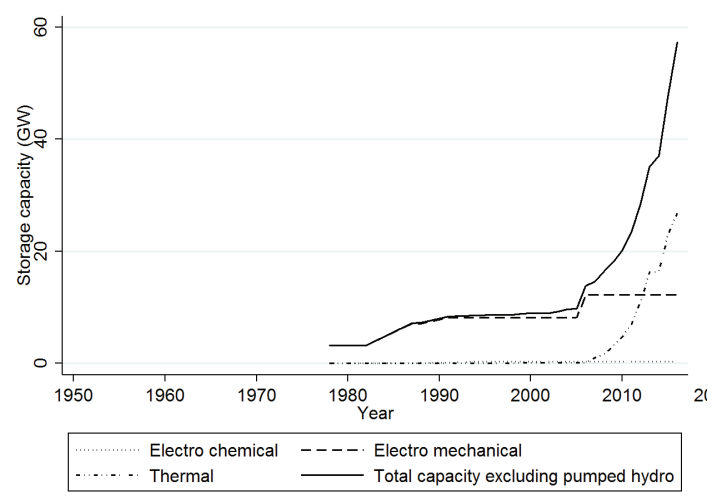

(b) Global total storage capacity excluding pumped hydro.

Figure B.1: Global total storage capacity, 1950-2016.

Thus, we do not expect installed storage capacity in pumped hydro to drive storage innovation in the recent decade. Our storage patents are related to other storing technologies like batteries, mechanical and chemical systems to storage electricity (see Table A.6 for a full description of storage patents), while installed capacity in these technologies is either modest (e.g. electro mechanical) or too recent (e.g. thermal) as of today. Therefore we do not expect these variables to have a statistically significant impact in our innovation analysis. 
Table B.19: Baseline specification with pumped hydro storage capacity as an explanatory variable.

\begin{tabular}{|c|c|c|c|c|c|c|}
\hline & \multicolumn{6}{|c|}{ Dependent variable: firm-level patents } \\
\hline & \multicolumn{3}{|c|}{ All countries } & \multicolumn{3}{|c|}{ Top five countries } \\
\hline & Renewable & Conventional & Storage & Renewable & Conventional & Storage \\
\hline \multicolumn{7}{|l|}{ Storage capacity: } \\
\hline L2.Firm level & $\begin{array}{c}1.1 \mathrm{e}-09 \\
(2.9 \mathrm{e}-08)\end{array}$ & $\begin{array}{l}-1.1 \mathrm{e}-08 \\
(5.3 \mathrm{e}-08)\end{array}$ & $\begin{array}{c}5.6 \mathrm{e}-08 \\
(5.3 \mathrm{e}-08)\end{array}$ & $\begin{array}{c}1.5 \mathrm{e}-08 \\
(3.0 \mathrm{e}-08)\end{array}$ & $\begin{array}{c}1.5 \mathrm{e}-08 \\
(5.6 \mathrm{e}-08)\end{array}$ & $\begin{array}{c}6.7 \mathrm{e}-08 \\
(5.5 \mathrm{e}-08)\end{array}$ \\
\hline \multicolumn{7}{|c|}{ Internal knowledge (marginal effects): } \\
\hline L2.Storage & $\begin{array}{c}.01127^{* * *} \\
(.00382)\end{array}$ & $\begin{array}{c}.00731^{* *} \\
(.0031)\end{array}$ & $\begin{array}{c}-.00732^{* * *} \\
(.00254)\end{array}$ & $\begin{array}{l}.01121^{* * *} \\
(.00402)\end{array}$ & $\begin{array}{l}.00636^{*} \\
(.00363)\end{array}$ & $\begin{array}{c}-.00686^{* * *} \\
(.00233)\end{array}$ \\
\hline L2.Renewable & $\begin{array}{c}-.00188^{* *} \\
(.00076)\end{array}$ & $\begin{array}{l}-.00045 \\
(.00175)\end{array}$ & $\begin{array}{c}.00197^{* * *} \\
(.00052)\end{array}$ & $\begin{array}{c}-.00169^{* *} \\
(.00078)\end{array}$ & $\begin{array}{l}.00061 \\
(.0014)\end{array}$ & $\begin{array}{c}.00196^{* * *} \\
(.00055)\end{array}$ \\
\hline L2.Conventional & $\begin{array}{l}-.00376 \\
(.00256)\end{array}$ & $\begin{array}{c}.00096 \\
(.00261)\end{array}$ & $\begin{array}{l}-.00129 \\
(.00525)\end{array}$ & $\begin{array}{l}-.00401 \\
(.00268)\end{array}$ & $\begin{array}{l}-.00128 \\
(.00207)\end{array}$ & $\begin{array}{l}-.00128 \\
(.00526)\end{array}$ \\
\hline \multicolumn{7}{|l|}{ External knowledge: } \\
\hline L2.Storage & $\begin{array}{c}.00037^{* * *} \\
(.00014)\end{array}$ & $\begin{array}{l}-.00019 \\
(.00022)\end{array}$ & $\begin{array}{c}3.6 \mathrm{e}-06 \\
(.00019)\end{array}$ & $\begin{array}{l}.00024^{*} \\
(.00015)\end{array}$ & $\begin{array}{l}-.00039 \\
(.00024)\end{array}$ & $\begin{array}{l}-.00026 \\
(.00018)\end{array}$ \\
\hline L2.Renewable & $\begin{array}{c}-.00011^{* * *} \\
(2.3 \mathrm{e}-05)\end{array}$ & $\begin{array}{l}-1.2 \mathrm{e}-06 \\
(4.3 \mathrm{e}-05)\end{array}$ & $\begin{array}{l}-1.2 \mathrm{e}-05 \\
(3.3 \mathrm{e}-05)\end{array}$ & $\begin{array}{c}-8.8 \mathrm{e}-05^{* * *} \\
(2.7 \mathrm{e}-05)\end{array}$ & $\begin{array}{c}3.5 \mathrm{e}-05 \\
(4.9 \mathrm{e}-05)\end{array}$ & $\begin{array}{c}3.6 \mathrm{e}-05 \\
(3.0 \mathrm{e}-05)\end{array}$ \\
\hline L2.Conventional & $\begin{array}{l}9.1 \mathrm{e}-05^{*} \\
(4.8 \mathrm{e}-05)\end{array}$ & $\begin{array}{l}-.00016^{*} \\
(9.2 \mathrm{e}-05)\end{array}$ & $\begin{array}{l}-3.3 \mathrm{e}-05 \\
(8.8 \mathrm{e}-05)\end{array}$ & $\begin{array}{c}6.4 \mathrm{e}-05 \\
(5.8 \mathrm{e}-05)\end{array}$ & $\begin{array}{c}-.00024^{* *} \\
(.0001)\end{array}$ & $\begin{array}{c}-.00013 \\
(9.3 \mathrm{e}-05)\end{array}$ \\
\hline \multicolumn{7}{|l|}{ Energy prices (firm level): } \\
\hline L1.Coal & $\begin{array}{c}-.3551^{* *} \\
(.1491)\end{array}$ & $\begin{array}{c}-.693^{* * *} \\
(.2057)\end{array}$ & $\begin{array}{l}-.1102 \\
(.2435)\end{array}$ & $\begin{array}{l}-.3481^{*} \\
(.1902)\end{array}$ & $\begin{array}{c}-.8505^{* * *} \\
(.2225)\end{array}$ & $\begin{array}{l}-.1879 \\
(.3004)\end{array}$ \\
\hline L1.Electricity & $\begin{array}{l}.05856 \\
(.2199)\end{array}$ & $\begin{array}{l}.2443 \\
(.3176)\end{array}$ & $\begin{array}{c}.142 \\
(.2985)\end{array}$ & $\begin{array}{l}.06661 \\
(.2465)\end{array}$ & $\begin{array}{l}.5007^{*} \\
(.2878)\end{array}$ & $\begin{array}{c}.3389 \\
(.3495)\end{array}$ \\
\hline \multicolumn{7}{|c|}{ Economic controls (firm level): } \\
\hline L1.GDP & $\begin{array}{l}-.06032 \\
(.08653)\end{array}$ & $\begin{array}{l}-.08459 \\
(.07787)\end{array}$ & $\begin{array}{c}.1397 \\
(.1453)\end{array}$ & $\begin{array}{l}-.1984^{*} \\
(.1061)\end{array}$ & $\begin{array}{c}-.3049^{* *} \\
(.1266)\end{array}$ & $\begin{array}{l}.08753 \\
(.3241)\end{array}$ \\
\hline L1.GDPcap & $\begin{array}{c}2.071^{* * *} \\
(.6718)\end{array}$ & $\begin{array}{c}.292 \\
(.7484)\end{array}$ & $\begin{array}{c}.532 \\
(.9447)\end{array}$ & $\begin{array}{l}1.465^{*} \\
(.8515)\end{array}$ & $\begin{array}{c}.4362 \\
(1.222)\end{array}$ & $\begin{array}{l}-2.727^{*} \\
(1.512)\end{array}$ \\
\hline L1.Popdensity & $\begin{array}{c}.1407^{*} \\
(.08065)\end{array}$ & $\begin{array}{l}-.0038 \\
(.1616)\end{array}$ & $\begin{array}{l}-.2185 \\
(.1807)\end{array}$ & $\begin{array}{c}.02666 \\
(.09164)\end{array}$ & $\begin{array}{c}.166 \\
(.1714) \\
\end{array}$ & $\begin{array}{l}-.3649 \\
(.2721)\end{array}$ \\
\hline Pre-sample history & Yes & Yes & Yes & Yes & Yes & Yes \\
\hline Pre-sample dummy & Yes & Yes & Yes & Yes & Yes & Yes \\
\hline Firm FE & Yes & Yes & Yes & Yes & Yes & Yes \\
\hline Year dummy & Yes & Yes & Yes & Yes & Yes & Yes \\
\hline Country dummy & No & No & No & Yes & Yes & Yes \\
\hline Year x Country dummy & No & No & No & No & No & No \\
\hline Number of observations & 47626 & 11982 & 11539 & 40930 & 10453 & 10319 \\
\hline
\end{tabular}

Significance levels: $\quad{ }^{* * *}: 1 \% \quad{ }^{* *}: 5 \% \quad{ }^{*}: 10 \%$

Note: The top five countries are the US, Japan, Germany, France, and Great Britain. 
Table B.20: Baseline specification with all storage capacity as an explanatory variable.

\begin{tabular}{|c|c|c|c|c|c|c|}
\hline & \multicolumn{6}{|c|}{ Dependent variable: firm-level patents } \\
\hline & \multicolumn{3}{|c|}{ All countries } & \multicolumn{3}{|c|}{ Top five countries } \\
\hline & Renewable & Conventional & Storage & Renewable & Conventional & Storage \\
\hline \multicolumn{7}{|l|}{ Storage capacity: } \\
\hline L2.Firm level & $\begin{array}{c}1.1 \mathrm{e}-09 \\
(2.9 \mathrm{e}-08)\end{array}$ & $\begin{array}{l}-1.1 \mathrm{e}-08 \\
(5.3 \mathrm{e}-08)\end{array}$ & $\begin{array}{c}5.6 \mathrm{e}-08 \\
(5.3 \mathrm{e}-08)\end{array}$ & $\begin{array}{c}1.5 \mathrm{e}-08 \\
(3.0 \mathrm{e}-08)\end{array}$ & $\begin{array}{c}1.5 \mathrm{e}-08 \\
(5.6 \mathrm{e}-08)\end{array}$ & $\begin{array}{c}6.7 \mathrm{e}-08 \\
(5.5 \mathrm{e}-08)\end{array}$ \\
\hline \multicolumn{7}{|c|}{ Internal knowledge (marginal effects): } \\
\hline L2.Storage & $\begin{array}{c}.01127^{* * *} \\
(.00382)\end{array}$ & $\begin{array}{c}.00731^{* *} \\
(.0031)\end{array}$ & $\begin{array}{c}-.00732^{* * *} \\
(.00254)\end{array}$ & $\begin{array}{c}.01121^{* * *} \\
(.00402)\end{array}$ & $\begin{array}{l}.00636^{*} \\
(.00363)\end{array}$ & $\begin{array}{c}-.00686^{* * *} \\
(.00233)\end{array}$ \\
\hline L2.Renewable & $\begin{array}{c}-.00188^{* *} \\
(.00076)\end{array}$ & $\begin{array}{l}-.00045 \\
(.00175)\end{array}$ & $\begin{array}{c}.00197^{\text {*** }} \\
(.00052)\end{array}$ & $\begin{array}{c}-.00169^{* *} \\
(.00078)\end{array}$ & $\begin{array}{l}.00061 \\
(.0014)\end{array}$ & $\begin{array}{c}.00196^{* * *} \\
(.00055)\end{array}$ \\
\hline L2.Conventional & $\begin{array}{l}-.00376 \\
(.00256)\end{array}$ & $\begin{array}{c}.00096 \\
(.00261)\end{array}$ & $\begin{array}{l}-.00129 \\
(.00525)\end{array}$ & $\begin{array}{l}-.00401 \\
(.00268)\end{array}$ & $\begin{array}{l}-.00128 \\
(.00207)\end{array}$ & $\begin{array}{l}-.00128 \\
(.00526)\end{array}$ \\
\hline \multicolumn{7}{|l|}{ External knowledge: } \\
\hline L2.Storage & $\begin{array}{l}.00037^{* * *} \\
(.00014)\end{array}$ & $\begin{array}{l}-.00019 \\
(.00022)\end{array}$ & $\begin{array}{c}3.6 \mathrm{e}-06 \\
(.00019)\end{array}$ & $\begin{array}{l}.00024^{*} \\
(.00015)\end{array}$ & $\begin{array}{l}-.00039 \\
(.00024)\end{array}$ & $\begin{array}{l}-.00026 \\
(.00018)\end{array}$ \\
\hline L2.Renewable & $\begin{array}{c}-.00011^{* * *} \\
(2.3 \mathrm{e}-05)\end{array}$ & $\begin{array}{c}-1.2 \mathrm{e}-06 \\
(4.3 \mathrm{e}-05)\end{array}$ & $\begin{array}{l}-1.2 \mathrm{e}-05 \\
(3.3 \mathrm{e}-05)\end{array}$ & $\begin{array}{c}-8.8 \mathrm{e}-05^{* * *} \\
(2.7 \mathrm{e}-05)\end{array}$ & $\begin{array}{c}3.5 \mathrm{e}-05 \\
(4.9 \mathrm{e}-05)\end{array}$ & $\begin{array}{c}3.6 \mathrm{e}-05 \\
(3.0 \mathrm{e}-05)\end{array}$ \\
\hline L2.Conventional & $\begin{array}{l}9.1 \mathrm{e}-05^{*} \\
(4.8 \mathrm{e}-05)\end{array}$ & $\begin{array}{l}-.00016^{*} \\
(9.2 \mathrm{e}-05)\end{array}$ & $\begin{array}{l}-3.3 \mathrm{e}-05 \\
(8.8 \mathrm{e}-05)\end{array}$ & $\begin{array}{c}6.4 \mathrm{e}-05 \\
(5.8 \mathrm{e}-05)\end{array}$ & $\begin{array}{c}-.00024^{* *} \\
(.0001)\end{array}$ & $\begin{array}{c}-.00013 \\
(9.3 \mathrm{e}-05)\end{array}$ \\
\hline \multicolumn{7}{|l|}{ Energy prices (firm level): } \\
\hline L1.Coal & $\begin{array}{c}-.3551^{* *} \\
(.1491)\end{array}$ & $\begin{array}{c}-.693^{* * *} \\
(.2057)\end{array}$ & $\begin{array}{l}-.1102 \\
(.2435)\end{array}$ & $\begin{array}{l}-.3481^{*} \\
(.1902)\end{array}$ & $\begin{array}{c}-.8505^{* * *} \\
(.2225)\end{array}$ & $\begin{array}{l}-.1879 \\
(.3004)\end{array}$ \\
\hline L1.Electricity & $\begin{array}{l}.05856 \\
(.2199)\end{array}$ & $\begin{array}{c}.2443 \\
(.3176)\end{array}$ & $\begin{array}{c}.142 \\
(.2985)\end{array}$ & $\begin{array}{l}.06661 \\
(.2465)\end{array}$ & $\begin{array}{l}.5007^{*} \\
(.2878)\end{array}$ & $\begin{array}{c}.3389 \\
(.3495)\end{array}$ \\
\hline \multicolumn{7}{|c|}{ Economic controls (firm level): } \\
\hline L1.GDP & $\begin{array}{l}-.06032 \\
(.08653)\end{array}$ & $\begin{array}{l}-.08459 \\
(.07787)\end{array}$ & $\begin{array}{c}.1397 \\
(.1453)\end{array}$ & $\begin{array}{l}-.1984^{*} \\
(.1061)\end{array}$ & $\begin{array}{c}-.3049^{* *} \\
(.1266)\end{array}$ & $\begin{array}{l}.08753 \\
(.3241)\end{array}$ \\
\hline L1.GDPcap & $\begin{array}{c}2.071^{* * *} \\
(.6718)\end{array}$ & $\begin{array}{c}.292 \\
(.7484)\end{array}$ & $\begin{array}{c}.532 \\
(.9447)\end{array}$ & $\begin{array}{l}1.465^{*} \\
(.8515)\end{array}$ & $\begin{array}{c}.4362 \\
(1.222)\end{array}$ & $\begin{array}{l}-2.727^{*} \\
(1.512)\end{array}$ \\
\hline L1.Popdensity & $\begin{array}{c}.1407^{*} \\
(.08065) \\
\end{array}$ & $\begin{array}{l}-.0038 \\
(.1616) \\
\end{array}$ & $\begin{array}{l}-.2185 \\
(.1807) \\
\end{array}$ & $\begin{array}{c}.02666 \\
(.09164) \\
\end{array}$ & $\begin{array}{c}.166 \\
(.1714) \\
\end{array}$ & $\begin{array}{l}-.3649 \\
(.2721) \\
\end{array}$ \\
\hline Pre-sample history & Yes & Yes & Yes & Yes & Yes & Yes \\
\hline Pre-sample dummy & Yes & Yes & Yes & Yes & Yes & Yes \\
\hline Firm FE & Yes & Yes & Yes & Yes & Yes & Yes \\
\hline Year dummy & Yes & Yes & Yes & Yes & Yes & Yes \\
\hline Country dummy & No & No & No & Yes & Yes & Yes \\
\hline Year x Country dummy & No & No & No & No & No & No \\
\hline Number of observations & 47626 & 11982 & 11539 & 40930 & 10453 & 10319 \\
\hline
\end{tabular}

Significance levels: $\quad{ }^{* * *}: 1 \% \quad{ }^{* *}: 5 \% \quad{ }^{*}: 10 \%$

Note: The top five countries are the US, Japan, Germany, France, and Great Britain. 
Table B.21: Baseline specification with pumped hydro storage capacity instead of storage innovation.

\begin{tabular}{|c|c|c|c|c|c|c|}
\hline & \multicolumn{6}{|c|}{ Dependent variable: firm-level patents } \\
\hline & \multicolumn{3}{|c|}{ All countries } & \multicolumn{3}{|c|}{ Top five countries } \\
\hline & Renewable & Conventional & Storage & Renewable & Conventional & Storage \\
\hline \multicolumn{7}{|l|}{ Storage capacity: } \\
\hline L2.Firm level & $\begin{array}{c}4.0 \mathrm{e}-08 \\
(3.0 \mathrm{e}-08)\end{array}$ & $\begin{array}{c}9.0 \mathrm{e}-10 \\
(4.8 \mathrm{e}-08)\end{array}$ & $\begin{array}{c}4.5 \mathrm{e}-08 \\
(3.6 \mathrm{e}-08)\end{array}$ & $\begin{array}{c}3.1 \mathrm{e}-08 \\
(3.1 \mathrm{e}-08)\end{array}$ & $\begin{array}{c}2.5 \mathrm{e}-08 \\
(4.9 \mathrm{e}-08)\end{array}$ & $\begin{array}{c}4.6 \mathrm{e}-08 \\
(3.7 \mathrm{e}-08)\end{array}$ \\
\hline L2.Regional level & $\begin{array}{c}6.1 \mathrm{e}-14 \\
(8.3 \mathrm{e}-13)\end{array}$ & $\begin{array}{c}4.8 \mathrm{e}-13 \\
(1.3 \mathrm{e}-12)\end{array}$ & $\begin{array}{c}7.5 \mathrm{e}-13 \\
(1.6 \mathrm{e}-12)\end{array}$ & $\begin{array}{l}-8.7 \mathrm{e}-14 \\
(8.6 \mathrm{e}-13)\end{array}$ & $\begin{array}{l}-1.9 \mathrm{e}-14 \\
(1.4 \mathrm{e}-12)\end{array}$ & $\begin{array}{c}6.6 \mathrm{e}-13 \\
(1.6 \mathrm{e}-12)\end{array}$ \\
\hline \multicolumn{7}{|c|}{ Internal knowledge (marginal effects): } \\
\hline L2.Renewable & $\begin{array}{l}-.00055 \\
(.00063)\end{array}$ & $\begin{array}{l}.00028 \\
(.0016)\end{array}$ & $\begin{array}{c}.00056 \\
(.00046)\end{array}$ & $\begin{array}{l}-.00043 \\
(.00063)\end{array}$ & $\begin{array}{c}.00038 \\
(.00155)\end{array}$ & $\begin{array}{c}.00055 \\
(.00048)\end{array}$ \\
\hline L2.Conventional & $\begin{array}{l}-.00366 \\
(.00249)\end{array}$ & $\begin{array}{c}.00068 \\
(.00238)\end{array}$ & $\begin{array}{l}-.00017 \\
(.0045)\end{array}$ & $\begin{array}{l}-.00386 \\
(.00256)\end{array}$ & $\begin{array}{c}.00098 \\
(.00303)\end{array}$ & $\begin{array}{c}.00012 \\
(.00458)\end{array}$ \\
\hline \multicolumn{7}{|l|}{ External knowledge: } \\
\hline L2.Renewable & $\begin{array}{c}-4.4 \mathrm{e}-05^{* * *} \\
(1.5 \mathrm{e}-05)\end{array}$ & $\begin{array}{l}-9.3 \mathrm{e}-06 \\
(2.5 \mathrm{e}-05)\end{array}$ & $\begin{array}{l}-1.7 \mathrm{e}-05 \\
(1.4 \mathrm{e}-05)\end{array}$ & $\begin{array}{c}-5.1 \mathrm{e}-05^{* * *} \\
(1.9 \mathrm{e}-05)\end{array}$ & $\begin{array}{c}5.9 \mathrm{e}-06 \\
(3.6 \mathrm{e}-05)\end{array}$ & $\begin{array}{l}-5.5 \mathrm{e}-06 \\
(1.5 \mathrm{e}-05)\end{array}$ \\
\hline L2.Conventional & $\begin{array}{l}-2.9 \mathrm{e}-05 \\
(4.9 \mathrm{e}-05)\end{array}$ & $\begin{array}{l}-3.5 \mathrm{e}-05 \\
(9.3 \mathrm{e}-05)\end{array}$ & $\begin{array}{c}4.4 \mathrm{e}-05 \\
(6.4 \mathrm{e}-05)\end{array}$ & $\begin{array}{l}-6.2 \mathrm{e}-05 \\
(5.9 \mathrm{e}-05)\end{array}$ & $\begin{array}{l}-5.5 \mathrm{e}-06 \\
(.00013)\end{array}$ & $\begin{array}{c}2.5 \mathrm{e}-05 \\
(7.2 \mathrm{e}-05)\end{array}$ \\
\hline \multicolumn{7}{|l|}{ Energy prices (firm level): } \\
\hline L1.Coal & $\begin{array}{l}-.3065^{*} \\
(.1769)\end{array}$ & $\begin{array}{c}-.6423^{* * *} \\
(.1818)\end{array}$ & $\begin{array}{c}-.1 \\
(.2607)\end{array}$ & $\begin{array}{l}-.3468 \\
(.2211)\end{array}$ & $\begin{array}{c}-.8266^{* * *} \\
(.2143)\end{array}$ & $\begin{array}{l}-.2546 \\
(.307)\end{array}$ \\
\hline L1.Electricity & $\begin{array}{l}-.00559 \\
(.2167)\end{array}$ & $\begin{array}{c}.3202 \\
(.2156)\end{array}$ & $\begin{array}{l}.00108 \\
(.3044)\end{array}$ & $\begin{array}{l}.07244 \\
(.2427)\end{array}$ & $\begin{array}{c}.2908 \\
(.3357)\end{array}$ & $\begin{array}{c}.2826 \\
(.3445)\end{array}$ \\
\hline \multicolumn{7}{|c|}{ Economic controls (firm level): } \\
\hline L1.GDP & $\begin{array}{l}-.1288 \\
(.1013)\end{array}$ & $\begin{array}{c}-.1133 \\
(.09377)\end{array}$ & $\begin{array}{l}.05079 \\
(.1708)\end{array}$ & $\begin{array}{c}-.2703^{* *} \\
(.1242)\end{array}$ & $\begin{array}{l}-.2433 \\
(.1564)\end{array}$ & $\begin{array}{l}-.2268 \\
(.1922)\end{array}$ \\
\hline L1.GDPcap & $\begin{array}{c}1.042 \\
(.7674)\end{array}$ & $\begin{array}{c}.1599 \\
(.8372)\end{array}$ & $\begin{array}{l}1.229 \\
(.88)\end{array}$ & $\begin{array}{c}.03168 \\
(.91)\end{array}$ & $\begin{array}{c}.6793 \\
(1.404)\end{array}$ & $\begin{array}{l}-.4119 \\
(1.053)\end{array}$ \\
\hline L1.Popdensity & $\begin{array}{c}.1845^{* *} \\
(.09133) \\
\end{array}$ & $\begin{array}{l}-.1917 \\
(.1193) \\
\end{array}$ & $\begin{array}{r}-.09345 \\
(.1825) \\
\end{array}$ & $\begin{array}{l}-.0072 \\
(.1175) \\
\end{array}$ & $\begin{array}{l}.03948 \\
(.1622) \\
\end{array}$ & $\begin{array}{c}-.5513^{* *} \\
(.2626) \\
\end{array}$ \\
\hline Pre-sample history & Yes & Yes & Yes & Yes & Yes & Yes \\
\hline Pre-sample dummy & Yes & Yes & Yes & Yes & Yes & Yes \\
\hline Firm FE & Yes & Yes & Yes & Yes & Yes & Yes \\
\hline Year dummy & Yes & Yes & Yes & Yes & Yes & Yes \\
\hline Country dummy & No & No & No & Yes & Yes & Yes \\
\hline Year x Country dummy & No & No & No & No & No & No \\
\hline Number of observations & 47626 & 11975 & 11545 & 40934 & 10461 & 10342 \\
\hline
\end{tabular}

Significance levels: $\quad{ }^{* * *}: 1 \% \quad{ }^{* *}: 5 \% \quad *: 10 \%$

Note: The top five countries are the US, Japan, Germany, France, and Great Britain. 


\section{B.ix Caveats}

Table B.22: Baseline specification with a year trend to address a potential incidental parameter problem.

\begin{tabular}{|c|c|c|c|c|c|c|}
\hline & \multicolumn{6}{|c|}{ Dependent variable: firm-level patents } \\
\hline & \multicolumn{3}{|c|}{ All countries } & \multicolumn{3}{|c|}{ Top five countries } \\
\hline & Renewable & Conventional & Storage & Renewable & Conventional & Storage \\
\hline \multicolumn{7}{|c|}{ Internal knowledge (marginal effects): } \\
\hline \multirow[t]{2}{*}{ L2.Storage } & $.01176^{* * *}$ & $.00712^{* *}$ & $-.00644^{* *}$ & $.01185^{* * *}$ & $.00648^{*}$ & $-.0055^{*}$ \\
\hline & $(.00365)$ & $(.00311)$ & $(.0032)$ & $(.00392)$ & $(.00331)$ & $(.0029)$ \\
\hline \multirow[t]{2}{*}{ L2.Renewable } & $-.00202^{* * *}$ & -.00039 & $.00169^{* * *}$ & $-.00182^{* *}$ & .00058 & $.00155^{* *}$ \\
\hline & $(.00078)$ & $(.00171)$ & $(.00057)$ & $(.00079)$ & $(.00136)$ & $(.00061)$ \\
\hline \multirow[t]{2}{*}{ L2.Conventional } & -.00354 & .00097 & .00089 & -.00373 & -.00115 & .00113 \\
\hline & $(.00265)$ & $(.00263)$ & $(.00704)$ & $(.00279)$ & $(.00232)$ & $(.00703)$ \\
\hline \multicolumn{7}{|l|}{ External knowledge: } \\
\hline \multirow[t]{2}{*}{ L2.Storage } & $.0005^{* * *}$ & -.00015 & $6.1 \mathrm{e}-05$ & $.00047^{* * *}$ & -.00016 & -.00014 \\
\hline & $(.00011)$ & $(.00019)$ & $(.00018)$ & $(.00012)$ & $(.00021)$ & $(.00022)$ \\
\hline \multirow[t]{2}{*}{ L2.Renewable } & $-9.9 \mathrm{e}-05^{* * *}$ & $-3.6 \mathrm{e}-05$ & $-7.5 \mathrm{e}-05^{* *}$ & $-9.4 \mathrm{e}-05^{* * *}$ & $-1.7 \mathrm{e}-05$ & $-5.0 \mathrm{e}-05$ \\
\hline & $(1.6 \mathrm{e}-05)$ & $(3.4 \mathrm{e}-05)$ & $(3.1 \mathrm{e}-05)$ & $(1.8 \mathrm{e}-05)$ & $(3.9 \mathrm{e}-05)$ & $(3.4 \mathrm{e}-05)$ \\
\hline \multirow[t]{2}{*}{ L2.Conventional } & $.00018^{* * *}$ & $-.00017^{*}$ & $-7.4 \mathrm{e}-05$ & $.00016^{* * *}$ & $-.00022^{* *}$ & -.00016 \\
\hline & $(5.1 \mathrm{e}-05)$ & $(9.0 \mathrm{e}-05)$ & $(.0001)$ & $(6.0 \mathrm{e}-05)$ & $(8.8 \mathrm{e}-05)$ & $(.00012)$ \\
\hline \multicolumn{7}{|l|}{ Energy prices (firm level): } \\
\hline \multirow[t]{2}{*}{ L1.Coal } & $-.7107^{* * *}$ & $-.9104^{* * *}$ & $-.4965^{* * *}$ & $-.8573^{* * *}$ & $-1.202^{* * *}$ & $-.5515^{* *}$ \\
\hline & $(.1114)$ & $(.1801)$ & $(.1886)$ & $(.144)$ & $(.189)$ & $(.2262)$ \\
\hline \multirow[t]{2}{*}{ L1.Electricity } & -.1697 & .03707 & -.1173 & -.1394 & .234 & -.1225 \\
\hline & $(.1965)$ & $(.2895)$ & $(.2277)$ & $(.2357)$ & $(.2833)$ & $(.2867)$ \\
\hline \multicolumn{7}{|c|}{ Economic controls (firm level): } \\
\hline \multirow[t]{2}{*}{ L1.GDP } & $-.1511^{*}$ & $-.1378^{* *}$ & .1307 & $-.2569^{* *}$ & $-.4028^{* * *}$ & .09506 \\
\hline & $(.08041)$ & $(.05724)$ & $(.138)$ & $(.107)$ & $(.1071)$ & $(.367)$ \\
\hline \multirow[t]{2}{*}{ L1.GDPcap } & $1.816^{* * *}$ & .4299 & .7402 & $1.459^{*}$ & .8547 & -.8048 \\
\hline & $(.5802)$ & $(.6991)$ & $(.7816)$ & $(.7903)$ & $(1.292)$ & $(1.205)$ \\
\hline \multirow[t]{2}{*}{ L1.Popdensity } & $.2014^{* * *}$ & .04655 & -.1197 & $.1626^{* *}$ & .2469 & -.03054 \\
\hline & $(.0703)$ & $(.1695)$ & $(.1537)$ & $(.08189)$ & $(.1802)$ & $(.3039)$ \\
\hline Pre-sample history & Yes & Yes & Yes & Yes & Yes & Yes \\
\hline Pre-sample dummy & Yes & Yes & Yes & Yes & Yes & Yes \\
\hline Firm FE & Yes & Yes & Yes & Yes & Yes & Yes \\
\hline Year trend & Yes & Yes & Yes & Yes & Yes & Yes \\
\hline Country dummy & No & No & No & Yes & Yes & Yes \\
\hline Year x Country dummy & No & No & No & No & No & No \\
\hline Number of observations & 50690 & 12882 & 11950 & 40930 & 10453 & 10319 \\
\hline
\end{tabular}

Note: The top five countries are the US, Japan, Germany, France, and Great Britain. 
Table B.23: Baseline estimates including the share of electricity production from hydroelectric sources (\% of total) for all countries and top-five innovative countries (marginal effects).

\begin{tabular}{|c|c|c|c|c|c|c|}
\hline & \multicolumn{6}{|c|}{ Dependent variable: firm-level patents } \\
\hline & \multicolumn{3}{|c|}{ All countries } & \multicolumn{3}{|c|}{ Top five countries } \\
\hline & Renewable & Conventional & Storage & Renewable & Conventional & Storage \\
\hline \multicolumn{7}{|c|}{ Internal knowledge (marginal effects): } \\
\hline L2.Storage & $\begin{array}{c}.01112^{* * *} \\
(.00376)\end{array}$ & $\begin{array}{l}.00703^{* *} \\
(.00309)\end{array}$ & $\begin{array}{c}-.00743^{* *} \\
(.00295)\end{array}$ & $\begin{array}{c}.01109^{* * *} \\
(.00401)\end{array}$ & $\begin{array}{l}.0081^{* *} \\
(.00325)\end{array}$ & $\begin{array}{c}-.00668^{* *} \\
(.0026)\end{array}$ \\
\hline L2.Renewable & $\begin{array}{c}-.00191^{* *} \\
(.00075)\end{array}$ & $\begin{array}{l}-.00056 \\
(.00171)\end{array}$ & $\begin{array}{c}.00186^{* * *} \\
(.00053)\end{array}$ & $\begin{array}{c}-.00175^{* *} \\
(.00077)\end{array}$ & $\begin{array}{c}-.0007 \\
(.00154)\end{array}$ & $\begin{array}{c}.00176^{* * *} \\
(.00057)\end{array}$ \\
\hline L2.Conventional & $\begin{array}{l}-.00369 \\
(.00254)\end{array}$ & $\begin{array}{c}.00079 \\
(.00229)\end{array}$ & $\begin{array}{l}-.00049 \\
(.00571)\end{array}$ & $\begin{array}{l}-.00383 \\
(.00265)\end{array}$ & $\begin{array}{l}.00164 \\
(.0029)\end{array}$ & $\begin{array}{l}-.00035 \\
(.00558)\end{array}$ \\
\hline \multicolumn{7}{|l|}{ External knowledge: } \\
\hline L2.Storage & $\begin{array}{l}.0003^{* *} \\
(.00013)\end{array}$ & $\begin{array}{r}-.00016 \\
(.0002)\end{array}$ & $\begin{array}{c}.00025 \\
(.00015)\end{array}$ & $\begin{array}{c}.00019 \\
(.00013)\end{array}$ & $\begin{array}{l}-.00016 \\
(.00017)\end{array}$ & $\begin{array}{l}-1.0 \mathrm{e}-06 \\
(.00015)\end{array}$ \\
\hline L2.Renewable & $\begin{array}{c}-8.7 \mathrm{e}-05^{* * *} \\
(2.1 \mathrm{e}-05)\end{array}$ & $\begin{array}{l}-5.4 \mathrm{e}-06 \\
(4.5 \mathrm{e}-05)\end{array}$ & $\begin{array}{c}-5.4 \mathrm{e}-05^{*} \\
(3.2 \mathrm{e}-05)\end{array}$ & $\begin{array}{c}-7.7 \mathrm{e}-05^{* * *} \\
(2.4 \mathrm{e}-05)\end{array}$ & $\begin{array}{c}7.8 \mathrm{e}-06 \\
(3.7 \mathrm{e}-05)\end{array}$ & $\begin{array}{c}-2.5 \mathrm{e}-05 \\
(3.1 \mathrm{e}-05)\end{array}$ \\
\hline L2.Conventional & $\begin{array}{c}1.7 \mathrm{e}-05 \\
(5.6 \mathrm{e}-05)\end{array}$ & $\begin{array}{l}-.00017 \\
(.00013)\end{array}$ & $\begin{array}{l}-1.5 \mathrm{e}-05 \\
(.00011)\end{array}$ & $\begin{array}{l}-4.2 \mathrm{e}-05 \\
(6.6 \mathrm{e}-05)\end{array}$ & $\begin{array}{l}-6.5 \mathrm{e}-05 \\
(.00013)\end{array}$ & $\begin{array}{l}-.00015 \\
(.00013)\end{array}$ \\
\hline \multicolumn{7}{|l|}{ Energy prices (firm level): } \\
\hline L1.Coal & $\begin{array}{c}-.3987^{* * *} \\
(.1494)\end{array}$ & $\begin{array}{c}-.5761^{* *} \\
(.2243)\end{array}$ & $\begin{array}{l}-.1899 \\
(.2321)\end{array}$ & $\begin{array}{l}-.482^{* *} \\
(.2015)\end{array}$ & $\begin{array}{c}-.9624^{* * *} \\
(.2237)\end{array}$ & $\begin{array}{l}-.3002 \\
(.3041)\end{array}$ \\
\hline L1.Electricity & $\begin{array}{c}.1231 \\
(.2058)\end{array}$ & $\begin{array}{r}-.08188 \\
(.2508)\end{array}$ & $\begin{array}{c}.1936 \\
(.2566)\end{array}$ & $\begin{array}{c}.1426 \\
(.2432)\end{array}$ & $\begin{array}{c}.3277 \\
(.2928)\end{array}$ & $\begin{array}{c}.2169 \\
(.3492)\end{array}$ \\
\hline \multicolumn{7}{|c|}{ Economic controls (firm level): } \\
\hline L1.GDP & $\begin{array}{c}-.02969 \\
(.1098)\end{array}$ & $\begin{array}{l}-.1503 \\
(.1047)\end{array}$ & $\begin{array}{l}.2262 \\
(.168)\end{array}$ & $\begin{array}{c}-.01912 \\
(.1721)\end{array}$ & $\begin{array}{l}-.1499 \\
(.1551)\end{array}$ & $\begin{array}{l}-.1559 \\
(.3013)\end{array}$ \\
\hline L1.GDPcap & $\begin{array}{c}1.886^{* * *} \\
(.724)\end{array}$ & $\begin{array}{c}.4749 \\
(.7169)\end{array}$ & $\begin{array}{c}.6296 \\
(.9296)\end{array}$ & $\begin{array}{l}.8495 \\
(.907)\end{array}$ & $\begin{array}{c}1.857 \\
(1.273)\end{array}$ & $\begin{array}{l}-1.291 \\
(.809)\end{array}$ \\
\hline L1.Popdensity & $\begin{array}{c}.2357^{* *} \\
(.09573)\end{array}$ & $\begin{array}{c}.0912 \\
(.1434)\end{array}$ & $\begin{array}{l}-.1706 \\
(.164)\end{array}$ & $\begin{array}{l}.2366^{*} \\
(.1272)\end{array}$ & $\begin{array}{l}.4134^{* *} \\
(.1882)\end{array}$ & $\begin{array}{l}-.5492 \\
(.3534)\end{array}$ \\
\hline L1.Hydro & $\begin{array}{l}-.00315 \\
(.00668)\end{array}$ & $\begin{array}{c}.00509 \\
(.01004)\end{array}$ & $\begin{array}{c}.02046 \\
(.01475)\end{array}$ & $\begin{array}{c}.00995 \\
(.01103)\end{array}$ & $\begin{array}{c}.00728 \\
(.01796)\end{array}$ & $\begin{array}{c}-.0012 \\
(.02717)\end{array}$ \\
\hline Pre-sample history & Yes & Yes & Yes & Yes & Yes & Yes \\
\hline Pre-sample dummy & Yes & Yes & Yes & Yes & Yes & Yes \\
\hline Firm FE & Yes & Yes & Yes & Yes & Yes & Yes \\
\hline Year dummy & Yes & Yes & Yes & Yes & Yes & Yes \\
\hline Country dummy & No & No & No & Yes & Yes & Yes \\
\hline Year x Country dummy & No & No & No & No & No & No \\
\hline Number of observations & 50655 & 12877 & 11942 & 40944 & 10460 & 10331 \\
\hline
\end{tabular}

Significance levels: $\quad{ }^{* * *}: 1 \% \quad{ }^{* *}: 5 \% \quad{ }^{*}: 10 \%$

Note: The top five countries are the US, Japan, Germany, France, and Great Britain. 